\title{
LEANING FORWARD
}

COVID-19 AND CHINA'S REFORM AGENDA

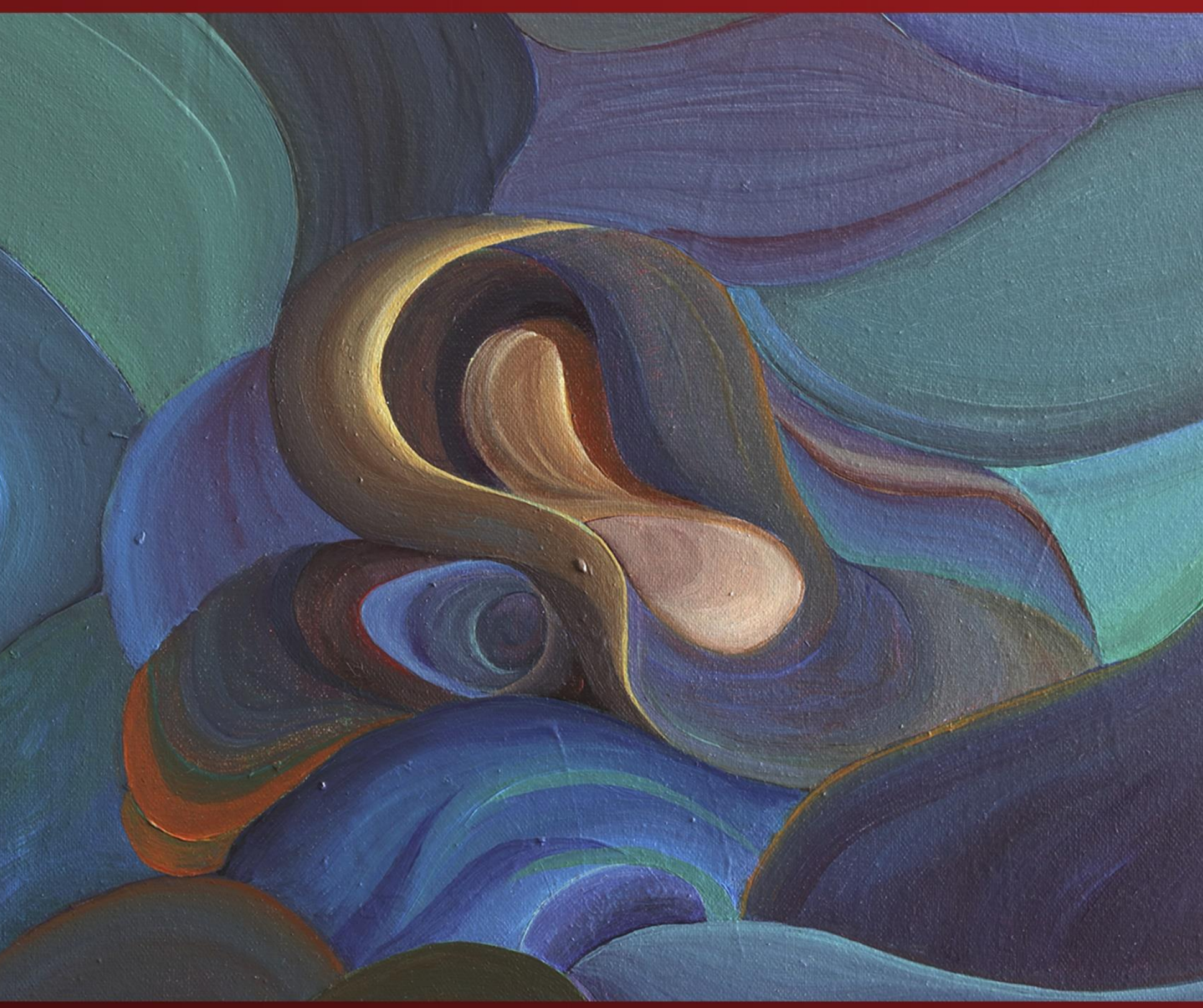


(C) 2020 International Bank for Reconstruction and Development / The World Bank

1818 H Street NW

Washington DC 20433

Telephone: 202-473-1000

Internet: www.worldbank.org

This work is a product of the staff of The World Bank. The findings, interpretations, and conclusions expressed in this work do not necessarily reflect the views of The World Bank, its Board of Executive Directors, or the governments they represent.

The World Bank does not guarantee the accuracy of the data included in this work. The boundaries, colors, denominations, and other information shown on any map in this work do not imply any judgment on the part of The World Bank concerning the legal status of any territory or the endorsement or acceptance of such boundaries.

\section{Rights and Permissions}

The material in this work is subject to copyright. Because The World Bank encourages dissemination of its knowledge, this work may be reproduced, in whole or in part, for noncommercial purposes as long as full attribution to this work is given.

Any queries on rights and licenses, including subsidiary rights, should be addressed to World Bank Publications, The World Bank Group, 1818 H Street NW, Washington, DC 20433, USA; fax: 202-5222625; e-mail: pubrights@worldbank.org.

Cover painting titled "Change" by Chinese Artist Li Zhengde, created during COVID-19 lockdown in Hunan Province in February 2020. Used with the permission of Li Zhengde. Further permission required for reuse. 


\section{Acknowledgements}

The July 2020 issue of China Economic Update was prepared by a team comprising Luan Zhao (Task Team Leader), Sebastian Eckardt, Ekaterine Vashakmadze, Maria Ana Lugo, Dinesh Nair, Dewen Wang, Ruslan G. Yemtsov, Ibrahim Saeed Chowdhury, Yang Huang, Chiyu Niu, Abayomi A. Alawode, Ergys Islamaj, Franz Ulrich Ruch, Woori Lee, Wei Han, Ileana Cristina Constantinescu, Yusha Li and Yan Li. Substantial contributions were received from Linghui Zhu, Josefina Posadas, Shiyong Wang, Michael J. Ferrantino and Michele Ruta. The team is grateful to Barbara Yuill for editing the report. Guidance and thoughtful comments from Aaditya Mattoo, Aparnaa Somanathan, Carlos Arteta, Deepak Mishra, Hassan Zaman, Irina Astrakhan, Martin Raiser, Philip O'Keefe and Rinku Murgai are gratefully acknowledged. The team would like to thank Tianshu Chen, Li Li, Xiaoting Li, Lin Yang, Ying Yu, Mingjie Li and Ruxin Zhao for support in the production and dissemination of this report. The findings, interpretations, and conclusions expressed in this report do not necessarily reflect the views of the Executive Directors of the World Bank or the Chinese government. Questions and feedback can be addressed to Li Li (1li2@ worldbank.org). 


\section{Table of Contents}

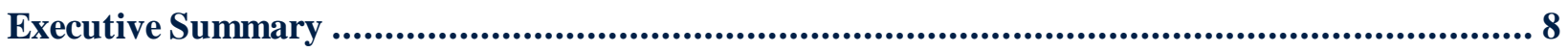

I. COVID-19 Shock ...................................................................................................12

II. Economic and Social Impacts...............................................................................15

Covid-19 led to a deep contraction of GDP in the first quarter ......................................... 15

Activity has started to rebound, but the recovery remains uneven ..................................... 17

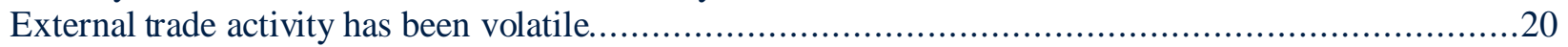

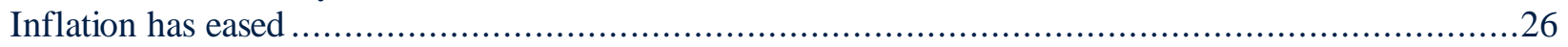

Labor market disruptions and income losses have taken an economic toll on households ..................22

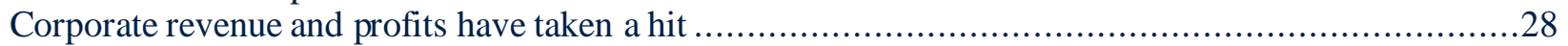

Credit risks are rising, foreshadowing potential banking sector troubles ...................................30

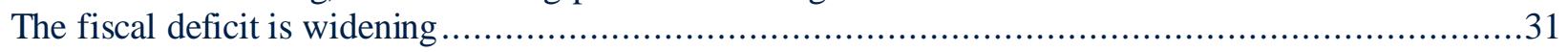

The pace of debt buildup has accelerated .................................................................... 31

Policies have aimed to cushion the economic and social impacts of the pandemic-induced downturn.....33

III. Outlook, Risks and Policy Considerations ..................................................................36

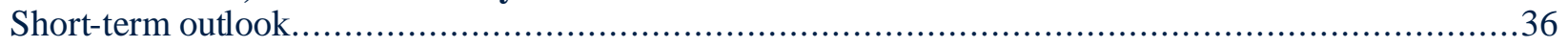

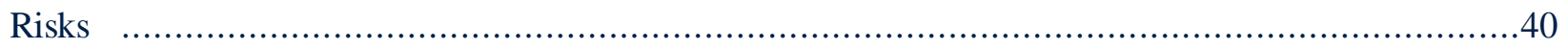

Policy considerations. ....................................................................................45

IV. Assessing the Distributional and Labor Market Impacts of COVID-19 in China ................50

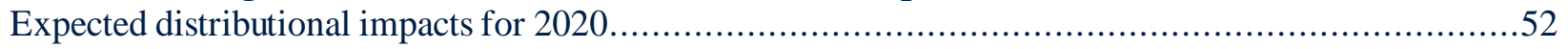

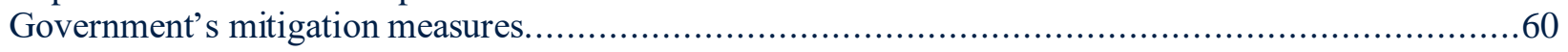

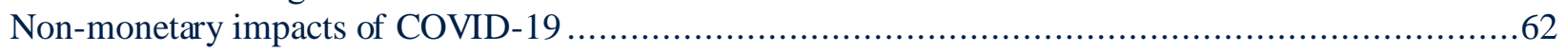

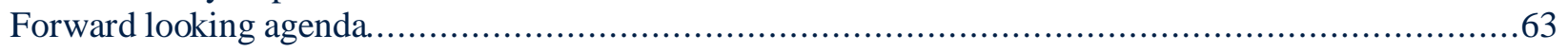

References....................................................................................................................66

\section{Figures}

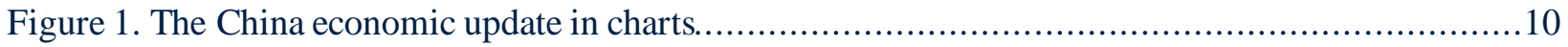

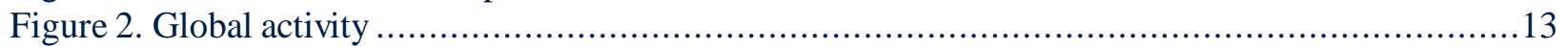

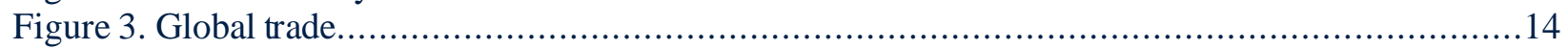

Figure 4. Global finance and commodity markets ......................................................... 14

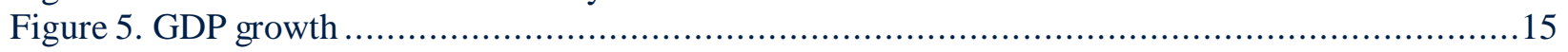

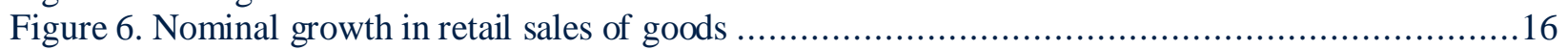

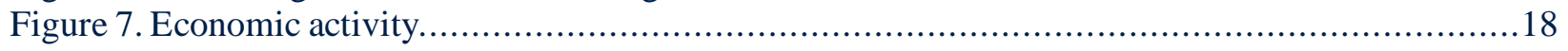

Figure 8. Consumer-facing services have recovered gradually ....................................... 19

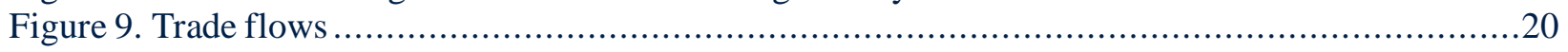

Figure 10. China-U.S. bilateral trade.....................................................................22

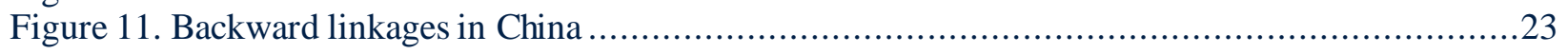

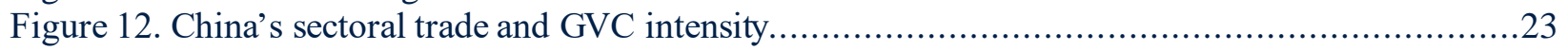

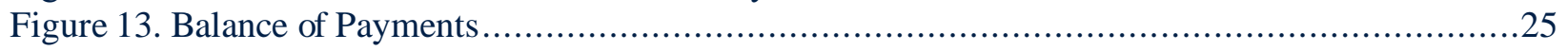

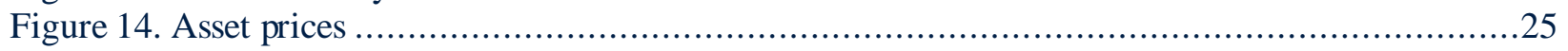

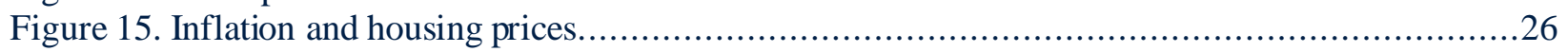

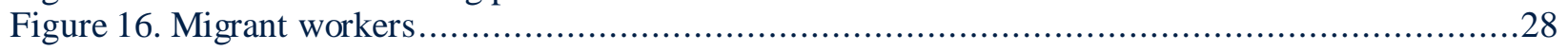

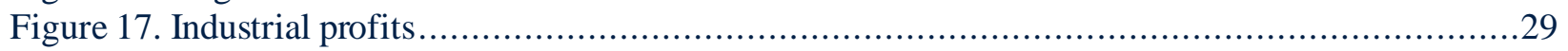

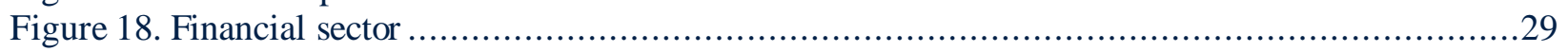

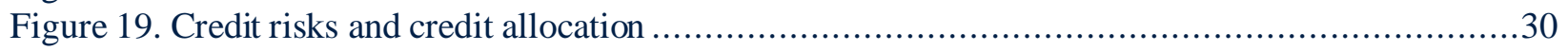

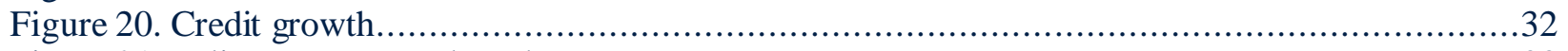

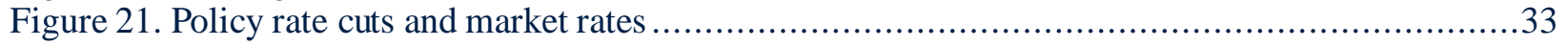




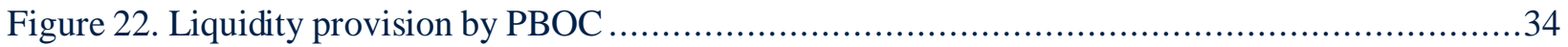

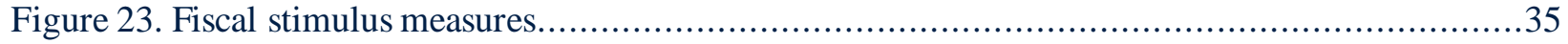

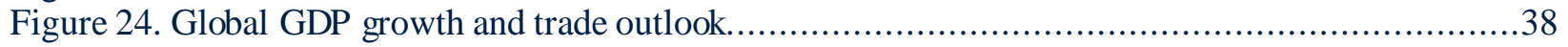

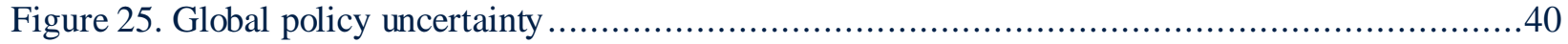

Figure 26. Growth projections under three alternative scenarios ....................................... 41

Figure 27. Coronavirus impact on output gap and potential growth......................................44

Figure 28. Per capita household disposable income and expenditure ...................................51

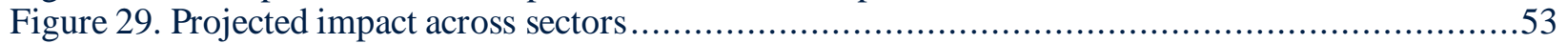

Figure 30. Share of households engaged in each of the sectors .......................................5

Figure 31. Share of total household income by source.....................................................55

Figure 32. Percentage change in per capita income in crisis scenarios relative to no-COVID benchmark 57

Figure 33. Percentage change in the poverty rate relative to 2018, in benchmark and crises scenarios ....59

Figure 34. Distribution of poor (aged 15-64) across scenarios........................................59

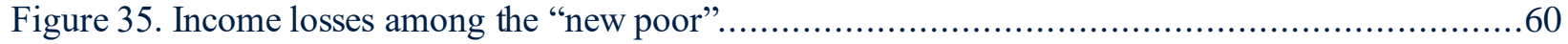

\section{Tables}

Table 1. China selected economic indicators (under baseline scenario) .....................................40

Table 2. Selected employment characteristics, by economic sectors ....................................53

Table 3. Key social protection and labor policies in response to COVID-19 ...............................61

\section{Boxes}

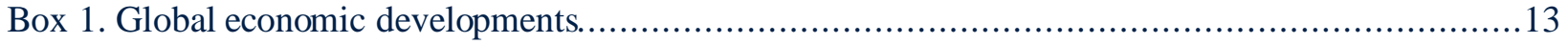

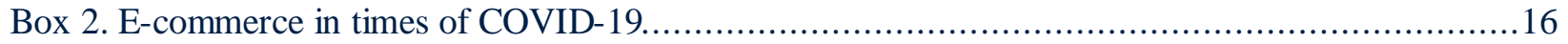

Box 3. Recent developments in China-U.S. bilateral trade............................................21

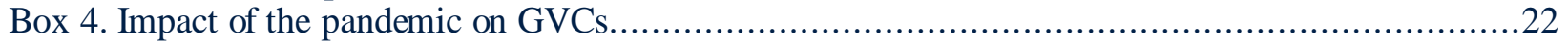

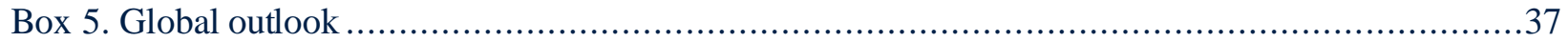

Box 6. Impact of COVID-19 on the output gap and potential growth in China...............................42

Box 7. Implementing a One Health approach for emerging infectious diseases ...........................48

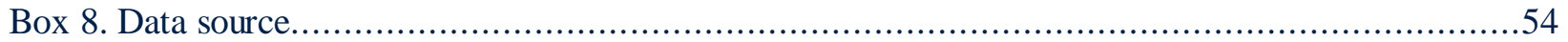

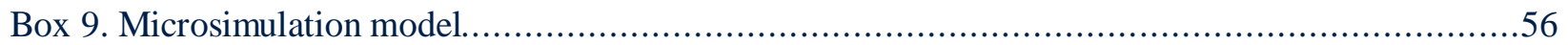

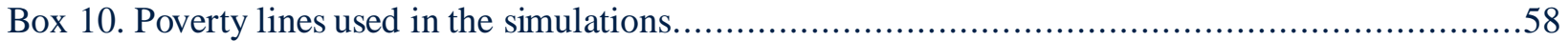




\section{List of Abbreviations}

\begin{tabular}{|c|c|}
\hline ALMP & Active Labor Market Programs \\
\hline AMR & Antimicrobial Resistance \\
\hline $\mathrm{CDC}$ & Center for Disease Control and Prevention \\
\hline COVID-19 & Coronavirus Disease 2019 \\
\hline CPI & Consumer Price Index \\
\hline DANMAP & Danish Integrated Antimicrobial Resistance Monitoring and Research Program \\
\hline DRC & China's Development Research Center of the State Council \\
\hline DXY & DingXiang Yuan \\
\hline EAP & East Asian and Pacific \\
\hline EBIT & Earnings Before Interest and Taxes \\
\hline EID & Emerging Infectious Disease \\
\hline EMDE & Emerging Market and Developing Economy \\
\hline EID & Emerging Infectious Disease \\
\hline FAI & Fixed Asset Investment \\
\hline FDI & Foreign Direct Investment \\
\hline FX & Foreign Exchange \\
\hline GDP & Gross Domestic Product \\
\hline GEP & Global Economic Prospects \\
\hline GPAI & Global Program on Avian Influenza \\
\hline GVC & Global Value Chain \\
\hline HAIRS & Human Animal Infections and Risk Surveillance \\
\hline HiAP & Health in All Policies \\
\hline HPAI & Highly Pathogenic Avian Influenza \\
\hline IMF & International Monetary Fund \\
\hline ILO & International Labour Organization \\
\hline LGB & Local Government Bond \\
\hline LGFV & Local Government Financing Vehicle \\
\hline LPR & Loan Prime Rate \\
\hline MDA & Mass Drug Administration \\
\hline MERS & Middle East Respiratory Syndrome \\
\hline MLF & Medium-term Lending Facility \\
\hline MOF & China Ministry of Finance \\
\hline MOHRSS & Ministry of Human Resources and Social Security \\
\hline MSE & Micro and Small Enterprise \\
\hline NBS & China National Bureau of Statistics \\
\hline NGO & Non-Governmental Organization \\
\hline $\mathrm{NHC}$ & National Health Commission \\
\hline NPL & Non-Performing Loan \\
\hline OECD & Organisation for Economic Co-operation and Development \\
\hline $\mathrm{OH}$ & One Health \\
\hline OIE & World Organization for Animal Health \\
\hline OPEC & Organization of Petroleum Exporting Countries \\
\hline PBOC & People's Bank of China \\
\hline PMI & Purchasing Managers' Index \\
\hline PPI & Producer Price Inflation \\
\hline PPP & Purchasing Power Parity \\
\hline Q1 & First Quarter \\
\hline Q2 & Second Quarter \\
\hline
\end{tabular}




$\begin{array}{ll}\text { Q3 } & \text { Third Quarter } \\ \text { Q4 } & \text { Fourth Quarter } \\ \text { QoQ } & \text { Quarter -on- Quarter } \\ \text { QR Code } & \text { Quick Response Code } \\ \text { ROA } & \text { Return on Assets } \\ \text { RRR } & \text { Reserve Requirement Ratio } \\ \text { SAAR } & \text { Seasonally Adjusted Annual Rate } \\ \text { SAFE } & \text { State Administration of Foreign Exchange } \\ \text { SARS } & \text { Severe Acute Respiratory Syndrome } \\ \text { SME } & \text { Small and Medium-sized Enterprise } \\ \text { SOE } & \text { State-Owned Enterprise } \\ \text { TSF } & \text { Total Social Financing } \\ \text { VAT } & \text { Value-added Tax } \\ \text { VIX } & \text { United States CBOE Volatility Index } \\ \text { WBG } & \text { World Bank Group } \\ \text { WHO } & \text { World Health Organization } \\ \text { WTO } & \text { World Trade Organization } \\ \text { y/y } & \text { Year-on-Year } \\ \text { ytd } & \text { Year-to-Date }\end{array}$




\section{Executive Summary}

Conditions in China and the rest of the world have changed dramatically since the launch of the last China Economic Update in mid-December 2019. The COVID-19 pandemic has taken a severe human toll, caused the deepest global recession in eight decades, and inflicted enormous damage on jobs and welfare worldwide. The global economy is projected to experience a sharp contraction this year, and more than 90 percent of Emerging Market and Developing Economies (EMDEs) are expected to experience contractions in per capita incomes, with global risks firmly on the downside-despite unprecedented policy support provided by major economies.

In China, the baseline forecast envisions a sharp slowdown of growth to 1.6 percent this year, which would mark the slowest expansion since 1976. While supply-side disruptions have largely eased, weak domestic and external demand continue to restrain the pace of recovery, despite measures taken to contain the economic fallout. Private consumption is projected to remain muted as a sharp decline in household incomes, rising unemployment, and lingering behavioral impacts of the pandemic are expected to weigh on consumption, especially of services involving face-to-face contact. Private investment is expected to remain subdued, reflecting strained corporate revenues and heightened uncertainty. Demand for Chinese goods from the rest of the world is projected to remain tepid amid a deep global recession, stringent border controls, and travel bans.

Even as economic activity rebounds, the shock is likely to leave lasting impacts on the economy. The pace of poverty reduction is expected to slow, reflecting labor dislocation and slower growth in household incomes. Without additional policy measures, 8-20 million fewer people are projected to escape poverty in 2020 (based on \$5.50/day 2011 Purchasing Power Parity (PPP)), compared to the pre-pandemic scenario. Self-employed workers and those in less secure, informal jobs, particularly migrant workers, are being especially hard hit. Meanwhile, debt levels - already elevated before the crisis - have increased sharply and eroded deleveraging gains made over the past two years. The fallout from the pandemic may also accelerate the secular slowdown of China's potential growth by weakening investment and supply chains that have been an important conduit for productivity gains over the past decades.

Risks to China's economic outlook are unusually high. On the downside, recurrent COVID-19 flareups could disrupt economic activity and dampen business and consumer sentiment to a greater extent than assumed in the baseline, despite efforts to suppress the spread of the virus. Externally, a deeper and more protracted global recession and escalating bilateral tensions between China and its key trading partners could also derail the recovery. On the upside, the slowdown could be less severe than projected in the baseline forecast if domestic and global consumer and investor confidence, boosted by effective policy measures, recover faster than anticipated, and if bilateral economic tensions ease.

While risks are exceptionally high, they can be partially mitigated by a forward-looking recovery strategy supported by good policies. The pandemic shock has exposed deeply connected economic, social, and environmental fragilities, confronting the authorities with new challenges while aggravating many preexisting ones. The recovery offers an opportunity to accelerate China's progress in rebalancing its economy toward more inclusive, sustainable, and greener growth

Monetary and financial sector policies will need to remain flexible to ensure abundant liquidity and keep market rates and bond yields low, easing the debt burden on households, firms, and governments. Subdued inflationary pressures provide ample room for keeping monetary policy accommodative without triggering inflation risks and/or capital outflows. At the same time, financial risks should be managed carefully while ensuring that the flow of credit to the real sector is not impeded. The confluence of a collapse of corporate profits, rising unemployment, and lost income has elevated credit risks in Chinese banks, and asset quality 
will likely deteriorate, especially when regulatory forbearance is tightened. Policy makers will therefore need to resume their focus on deleveraging and de-risking the economy once activity has normalized and confidence has been restored.

Given the risks and limitation of a credit-fueled rebound, fiscal policies will need to play the leading role in supporting the recovery. But fiscal stimulus measures should be designed in a way that contributes to achieving more inclusive and greener growth over the medium-term. Specifically, policy makers should aim at closing the gaps in China's social protection coverage, building on the COVID-driven expansion of the system. This would not only help protect workers and households from the distress caused by job and income losses but also boost private consumption. Ensuring equitable access to vital public services, such as health care and education including the provision of distance learning during school closures, will be critical to minimize lasting impacts on human capital formation. Public investment programs to support China's recovery should be designed so that they accelerate the transition towards a carbon-neutral, cleaner, and greener economy.

Structural policies should focus on enabling the reallocation of resources and facilitating adjustments to the post-pandemic economic realities. Businesses needed support to prevent a surge in pandemic-induced bankruptcies and job losses during the downturn. However, as the economy recovers, financial lifelines to firms will need to unwind. Especially if corporate distress reflects deeper underlying solvency rather than temporary liquidity issues, including over-leveraged balance sheets, bankruptcy proceedings may be the appropriate strategy. Intensifying "hukou" (household residency registration system) reform and enhancing access to and portability of social services would ease the movement of labor from firms and sectors suffering more persistent damage to expanding sectors, firms, and locations. Further enhancing market access, including in the relatively closed service sectors, could boost investment and accelerate knowledge and technology diffusion, and also help ease lingering geo-economic tensions that may be further exacerbated by the pandemic-induced recession.

In China, the rate of new infections has slowed considerably since late February, and restrictions on economic and social life have been gradually lifted. Keeping any renewed outbreaks effectively under control will remain a short-term priority to enable a safe recovery. Beyond the immediate public health response, the pandemic has revealed shortcomings in disease surveillance and control. The crisis offers an opportunity to close these gaps by moving decisively towards a One Health approach, based on multisectoral cooperation in mapping and reducing public health risks, active case-based surveillance and timely reporting, improved surge capacity, and strengthened international collaboration.

\begin{tabular}{lccccc} 
China Economic Outlook & $\mathbf{2 0 1 7}$ & $\mathbf{2 0 1 8}$ & $\mathbf{2 0 1 9}$ & $\mathbf{2 0 2 0 f}$ & $\mathbf{2 0 2 1 \boldsymbol { f }}$ \\
\hline Real GDP growth (\%) & 6.9 & 6.7 & 6.1 & 1.6 & 7.9 \\
CPI (\% change) & 1.6 & 2.1 & 2.9 & 2.1 & 2.3 \\
Current account balance (\% of GDP) & 1.6 & 0.2 & 1.0 & 0.7 & 0.4 \\
Augmented fiscal balance (\% of GDP) $^{\text {a }}$ & -3.9 & -4.6 & -6.4 & -11.8 & -5.4 \\
\hline
\end{tabular}

Sources: World Bank

Notes: $f=$ forecast.

(a) World Bank staff calculations. The a ugmented fiscal balance (narrow definition) a dds up the public finance budget, the government fund budget, the state capital management fund budget, and the social security fund budget. 
Figure 1. The China economic update in charts

The pandemic has taken a significant human toll...

A. Covid-19 official death

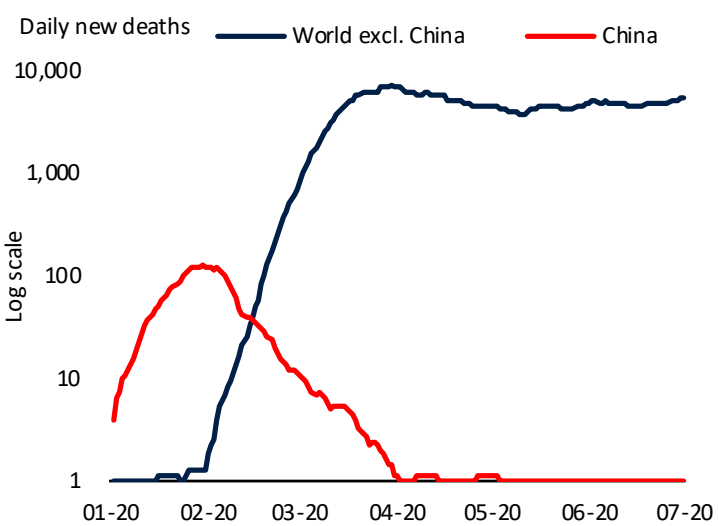

As China rolled back lockdown measures, activity started to rebound...

C. Activity in China

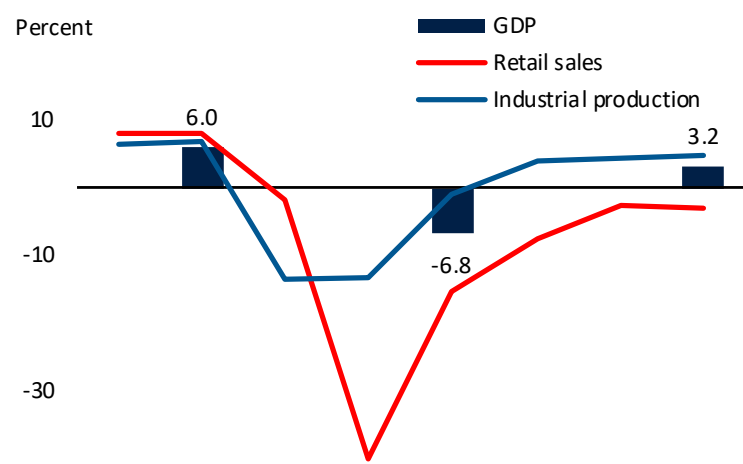

$-50$

Nov-19 Dec-19 Jan-20 Feb-20 Mar-20 Apr-20 May-20 Jun-20

...despite policy measures to contain the downturn.

E. Composition of augmented deficit Percent in GDP

$\begin{array}{ll}\text { Draw down of fiscal reserves } & \text { Special LG-bonds } \\ \text { Public finance budget deficit } & \text { Special T-bonds }\end{array}$

Public finance budget deficit
Social security fund budget deficit $\triangle$ Augmented deficit

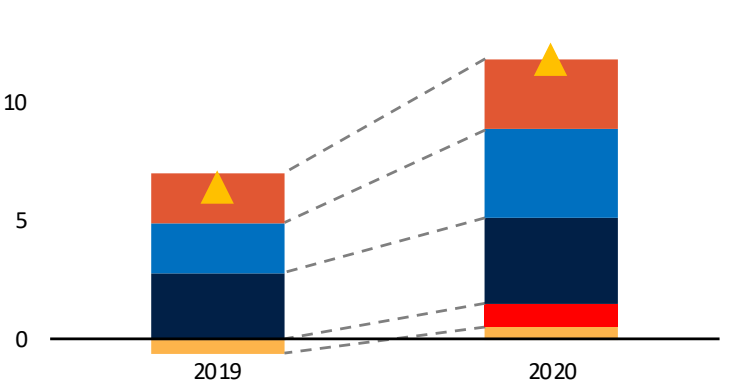

$-5$
... and led to a sharp contraction of GDP in China and in the rest of the world.

B. GDP growth

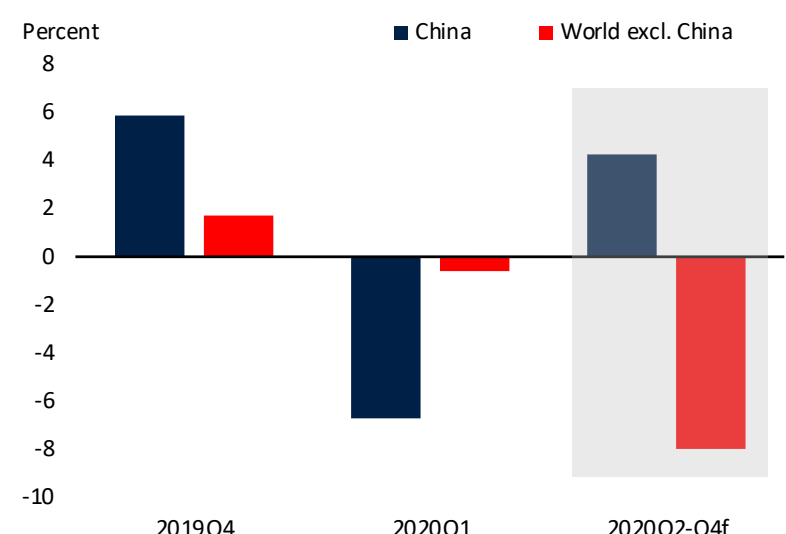

...but GDP growth is projected to slow sharplythis year...

D. GDP growth, long term

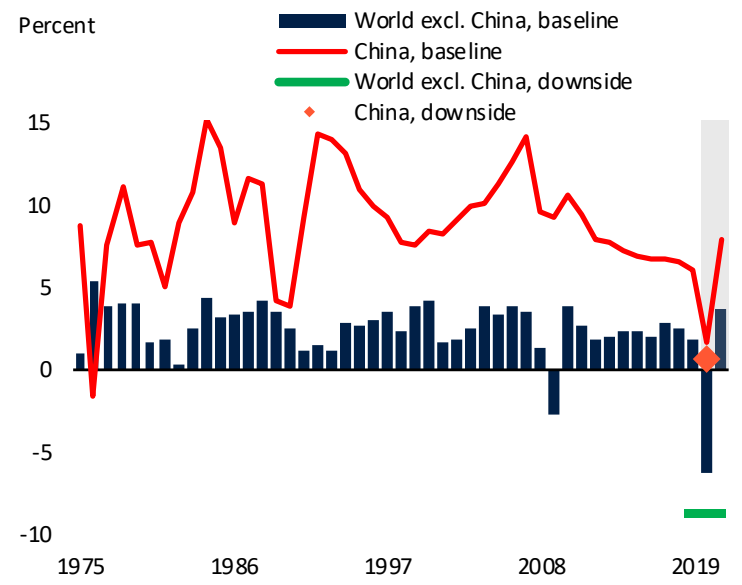

F. Liquidity provision by PBOC

Percent in GDP

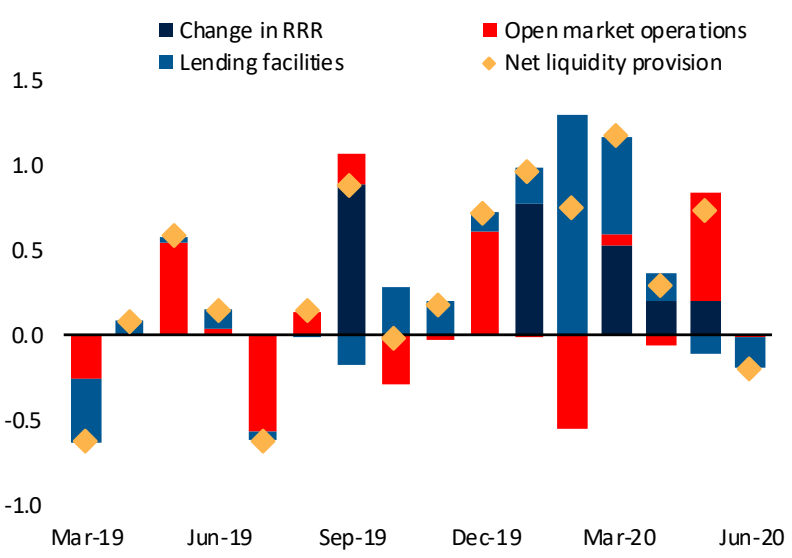




\section{The economic downturn will slow the pace of poverty reduction...}

G. Poverty headcount

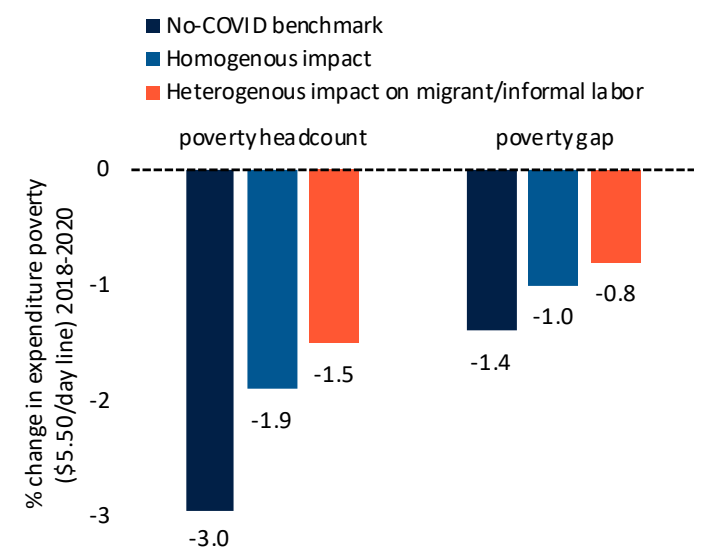

...and further elevate already high debtlevels...

\section{H. Total credit and nominal GDP growth}

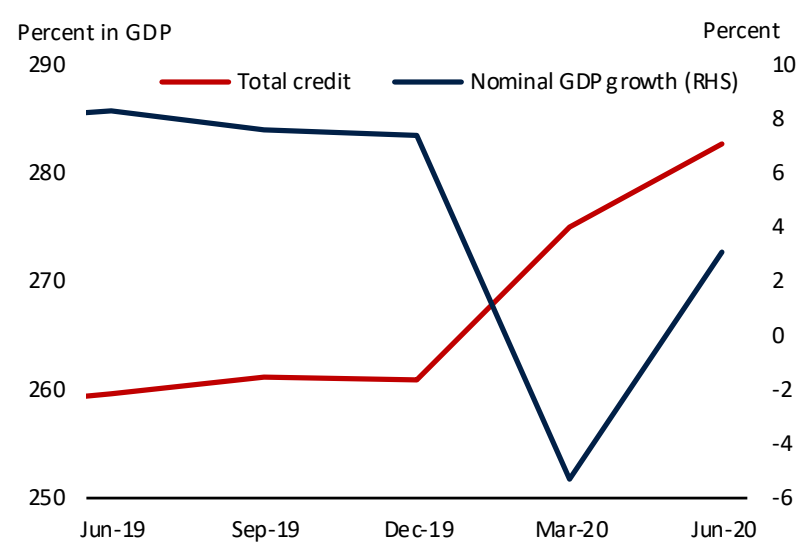

I.

$$
\text { GDP and potential growth }
$$

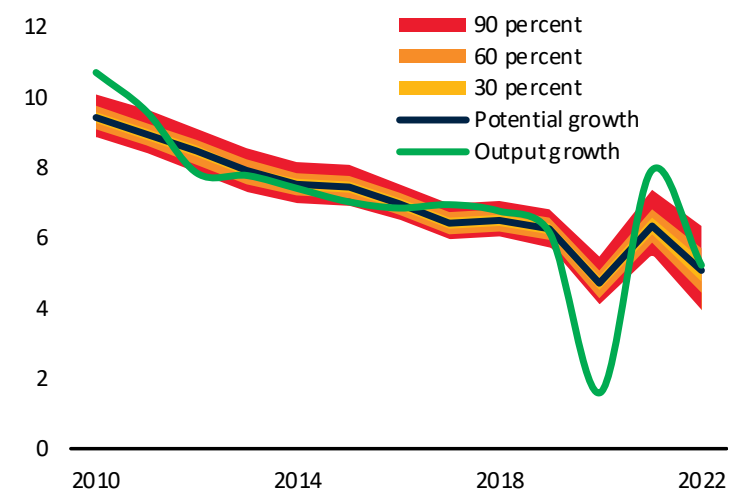

...and could reduce potential growth.

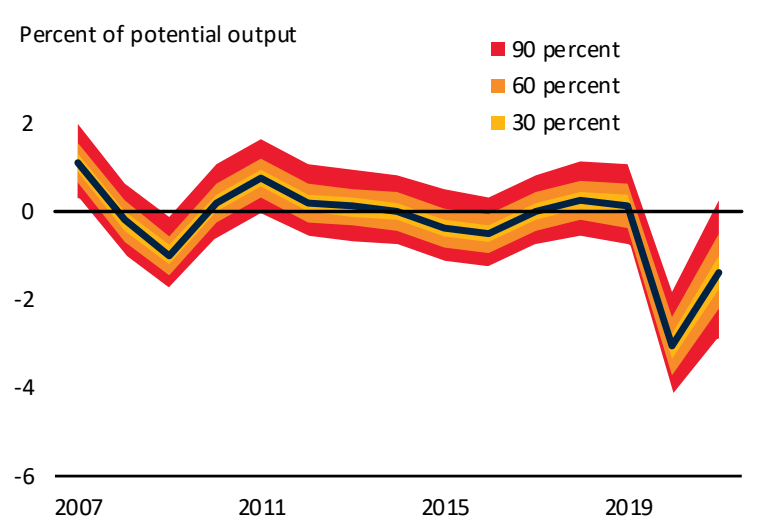

Source: Johns Hopkins University; World Health Organization (WHO); DingXiangYuan (DXY); China National Bureau of Statistics (NBS); Haver Analytics; China Family Panel Survey 2018; People's Bank of China (PBOC); Ministry of Finance (MOF); Penn World Table 9.1; World Development Indicators; The Consensus Forecasts; World Bank estimates and projections.

Notes: A. Johns Hopkins University based on figures reported by the WHO and DXY. DXY is an online community for physicians, health care professionals, pharmacies and facilities in China. B. 2020Q2-Q4 growth rates for world excluding China present the estimates based on the full year growth projections published in the World Bank June 2020 Global Economic Prospects (GEP). GDP growth in year-on-year percent change. C. Industrial production, retail sales and GDP growth in yearon-year percent change. D. 2020-2021 growth rates for world excluding China present the estimates based on the full year growth projections published in the World Bank June 2020 GEP. E. Fiscal budget balance as share of GDP. F. Lending facilities refer to net liquidity injection provided by the PBOC through standing lending facility (SLF), the medium-term lending facility (MLF), the targeted medium-term lending facility (TMLF), the pledged supplementary lending (PSL), the special-purpose refinancing (SPRF) and the special relending or rediscounting facilities. G. Poverty is calculated using the $\$ 5.50 /$ day line (2011 PPP) and consumption as the welfare aggregate, adjusting the thresholds to match World Bank projections for 2018, based on NBS household expenditure data and GDP growth. "No-COVID Benchmark" refers to the scenario without COVID-19, "homogenous impact" is based on GDP projections by economic sectors, and "heterogenous impact on migrant/informal labor" uses GDP projections as in "homogenous impact", but also allows for heterogeneity of the labor income shock across formal and informal workers and migrants. H. Total debt is defined as a sum of domestic and external debt, including household, nonfinancial corporate, and public sector debt expressed as a share of the four-month average quarterly, seasonally adjusted GDP. Last observation is 2020Q2. I. Based on estimates from a modified multivariate filter model of World Bank (2018). Last observation is 2020Q2. Error bands reflect 90 percent confidence intervals based on model estimates. J. Based on the estimates from a modified multivariate filter model of World Bank (2018). Error bands reflect 90 percent confidence intervals based on model estimates. 


\section{COVID-19Shock}

Conditions in China and the rest of the world have changed in dramatic and unexpected ways since the launch of the last China Economic Update in mid-December 2019 (Box 1). The COVID-19 pandemic has taken a severe human toll and exacted the deepest global recession in eight decades, causing enormous damage to jobs and welfare worldwide (World Bank 2020d). The global economy is projected to contract sharply this year, more than 90 percent of EMDEs are expected to experience contractions in per capita incomes, and globally about 70-100 million people could fall back into poverty (World Bank 2020c). ${ }^{1}$

Covid-19 and the measures to contain it triggered a combined demand and supply shock. On the supply side, measures to contain the outbreak disrupted the flow of intermediate goods, labor, and production. Labor supply declined, due to restrictions on movement and human interaction, the illness of workers and family members, and school closures. ${ }^{2}$ Migrant labor, a significant part of the workforce in China, was unable to return to places of work due to travel restrictions. Delays in input deliveries and problems with financing caused operational challenges for firms.

On the demand side, necessary but costly containment measures and behavioral responses reduced demand for goods and services, especially those involving human-to-human contact. Sectors particularly hard hit from decreasing demand include transportation, tourism, and traditional retail services. As a result, a substantial share of private consumption requiring social interaction was lost in $2020 \mathrm{H} 1$, in China and in the rest of the world. Investment also contracted because of disruptions in economic activity, heightened policy uncertainty, and rising financing costs.

The demand shock will likely outweigh and outlast the supply shock. While supply side constraints have eased, weak domestic and external demand continues to restrain the pace of recovery. Private consumption will likely remain subdued, due to the lasting effects of income losses and labor dislocation. Given strained corporate revenue and global uncertainty, private investment is also likely to remain relatively weak in the immediate future. External demand is expected to remain under pressure as a major and broad-based recession embroils the global economy, even if demand for some export products may remain resilient.

Policymakers across the world have provided significant policy support to reduce the human, social, and economic impacts of the pandemic. Emergency measures have generally focused on expanding hospital and healthcare capacities, protecting the incomes of workers and supporting companies. Monetary policies in major economies have been eased through cuts in interest rates, reserve requirements, and enhanced asset purchase programs. The fiscal policy support announced globally already far exceeds fiscal measures enacted during the 2008-09 global financial crisis.

Despite the unprecedented policy support, COVID-19 is expected to have a significant and lasting impact on China and the global economy. The total number of COVID-19 cases continues to rise globally, even if there are signs of an activity rebound, led by countries which have already started to reopen their economies. While nationwide lockdowns are gradually rolled back in parts of Asia and Europe, many countries around the world continue to enforce travel restrictions and apply some social distancing, quarantine, and isolation measures. Even in countries that managed to contain the spread of the virus, there

\footnotetext{
${ }^{1}$ See also (Kilbourne, E.D. 2004).

${ }^{2}$ See (Keogh-Brown, M.R., Smith, R.D., Edmunds, J.W., and Beutels, P. 2010).
} 
is a risk related to potential recurrent outbreaks. Some social distancing and international mobility restrictions are expected to remain in place for some time and weigh on economic activity until a vaccine or effective treatment for Covid-19 become available. Against this backdrop, China's near- and mediumterm economic prospects will continue to be shaped by the evolution of the pandemic.

\section{Box 1. Global economic developments ${ }^{3}$}

The COVID-19 pandemic has led to a deep global recession (Figure 2.A). The rapid spread of the virus, and associated control measures, have sharply curbed consumption and investment in $2020 \mathrm{H} 1$, especially in sectors requiring social interaction. This weakness was widespread, affecting both advanced economies and emerging market and developing economies (World Bank 2020b). More recently, global activity has begun to rebound following a gradual relaxation of lockdown measures, with the global manufacturing PMI rising to 47.76 in June, compared to its nadir of 39.58 points in April (Figure 2.B). Still, global output is set to contract sharply in 2020 - nearly three times larger than the contraction experienced in 2009, during the global financial crisis and the deepest global recession since the Second World War (World Bank 2020b).

\section{Figure 2. Global activity}
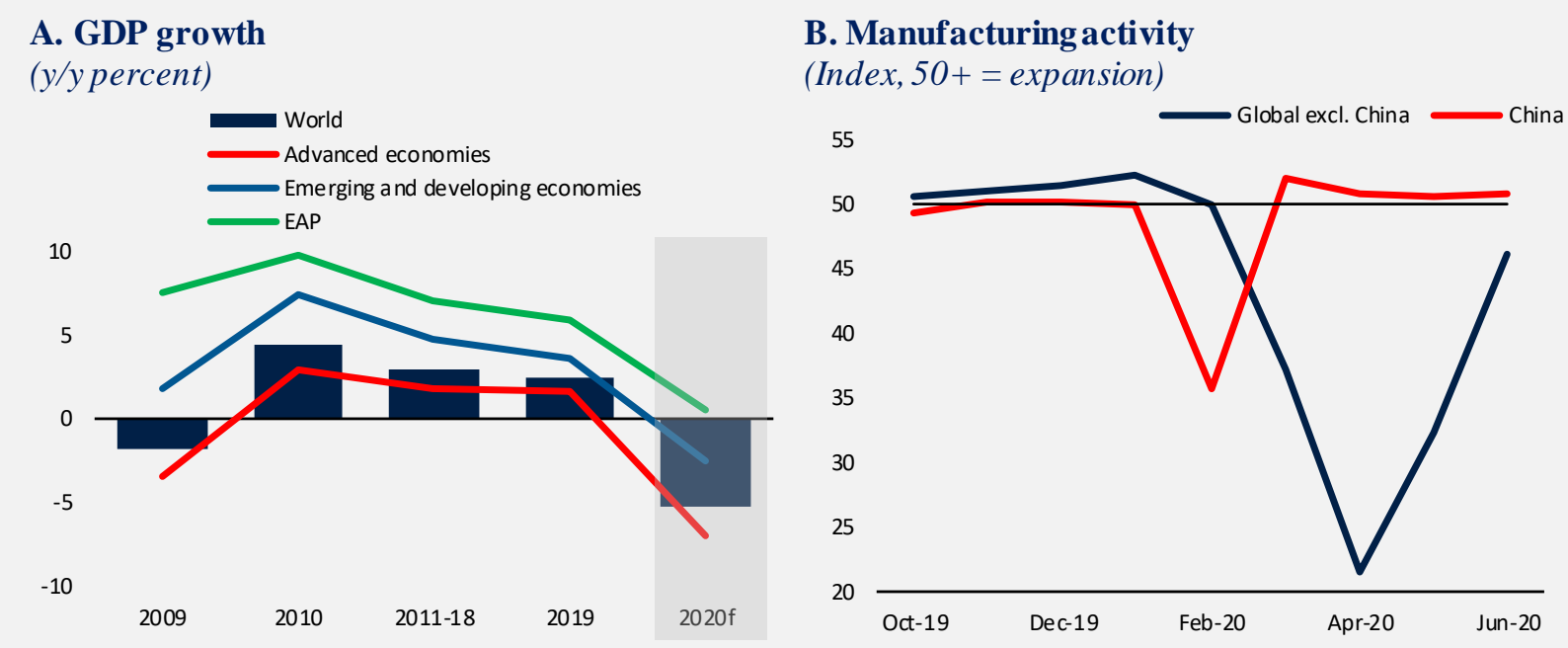

Source: Haver Analytics; World Bank.

Note: A. EAP=developing East Asia and Pacific region. Aggregate growth ra tes a re calculated using GDP weights at 2010 prices and market exchange rates. Data reflect the forecasts published in the World Bank's June 2020 GlobalEconomic Prospects report (World Bank 2020d). B. Reading below 50 indicate contraction in economic activity. Horizontal line in dicates ex pansionary threshold.

Global import demand plummeted in 2020H1, reflecting widespread control measures, major disruptions in international travel, tourism, and supply chains. Global tourist arrivals declined by nearly 100 percent, while the number of commercial flights was down about 70 percent. Disruptions to production and international transport have increased the risk that critical inputs will be unavailable, potentially leading to cascading production shortfalls in global value chains (GVCs). Most recently, global trade has started to show signs of incipient rebound, with the manufacturing new export orders rising to 43.4 in June, compared to its nadir of 27.1 points in April. This uptick notwithstanding, the sharp fall in activity in the first half of this year is expected to contribute to a contraction in global trade

\footnotetext{
${ }^{3}$ Draws heavily on the World Bank June 2020 Global Economic Prospects report (World Bank 2020d).
} 
of about 13.4 percent in 2020 - larger than experienced during the global financial crisis (Figure 3).

\section{Figure 3. Global trade}

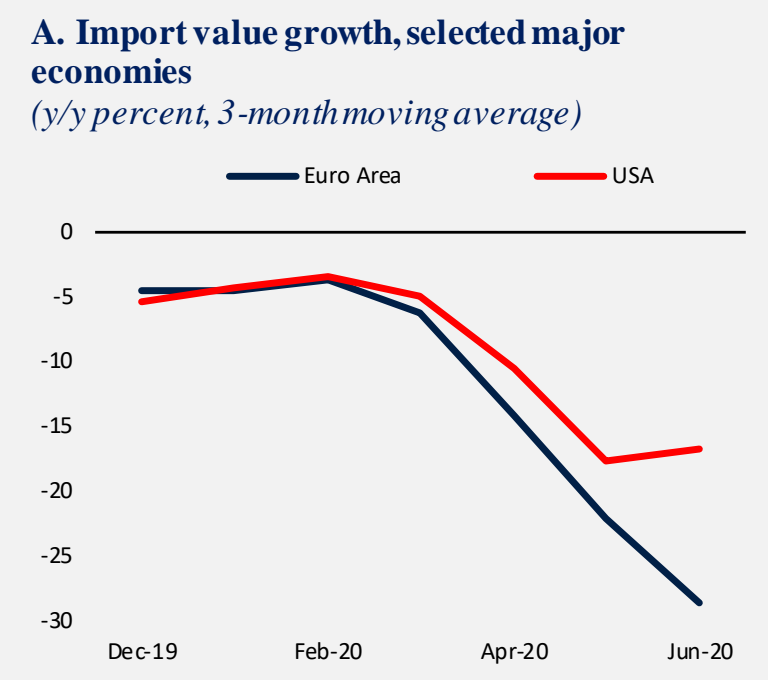

\section{B. Global new export orders (Index, 50+ = expansion)}

(y/y percent, 3-month moving average)

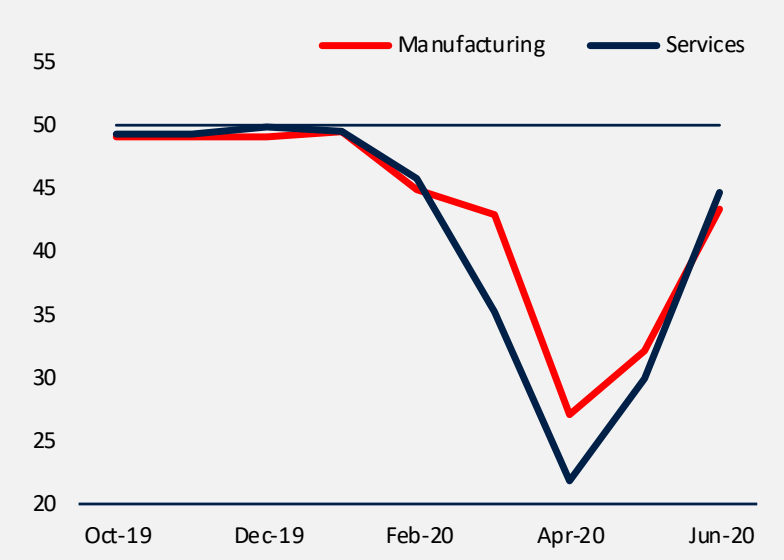

Source: Haver Analytics; World Bank.

Note: A. Da ta includeonly goods. B. New export orders a re measured by PMI.

Central banks around the world have aggressively eased monetary policy and provided liquidity support to avoid shortages in credit markets. The Federal Reserve cut its policy rates to close to zero. Large-scale liquidity injections by major central banks and a gradual relaxation of lockdown measures in some countries recently contributed to an improvement of global risk sentiment. Capital outflows from EMDEs, which exceeded the worst period of the global financial crisis at the outset of the pandemic, have subsided. Equity market valuations, which fell sharply as the coronavirus outbreak accelerated globally, have recovered some of their earlier losses. The VIX volatility index, which more than quadrupled in March, fell below double its February value by late-July (Figure 4.A).

Most commodity prices declined in $2020 \mathrm{H} 1$ as measures implemented to slow the spread of the pandemic led to a collapse in global demand (Figure 4.B). By one measure, Brent crude oil prices fell 85 percent from late January to mid-April before recovering in May and June and remain about 40 percent below the late-January level. Global oil production is starting to decline, although at a markedly slower pace than at which demand had fallen. In April, OPEC and its partners agreed to new production cuts, starting with a reduction of $9.7 \mathrm{mb} / \mathrm{d}$ in May and June - which was recently extended to include Julyand gradually tapering thereafter.

Figure 4. Global finance and commodity markets
A. Dow Jones global index and U.S. CBOE VIX, 2007-2020
(Dow Jones global index (Dec. 31, 1991=100). U.S. $\quad$ (Index, nominalterm, 2010=100)
CBOE volatilityindex (VIX)) 


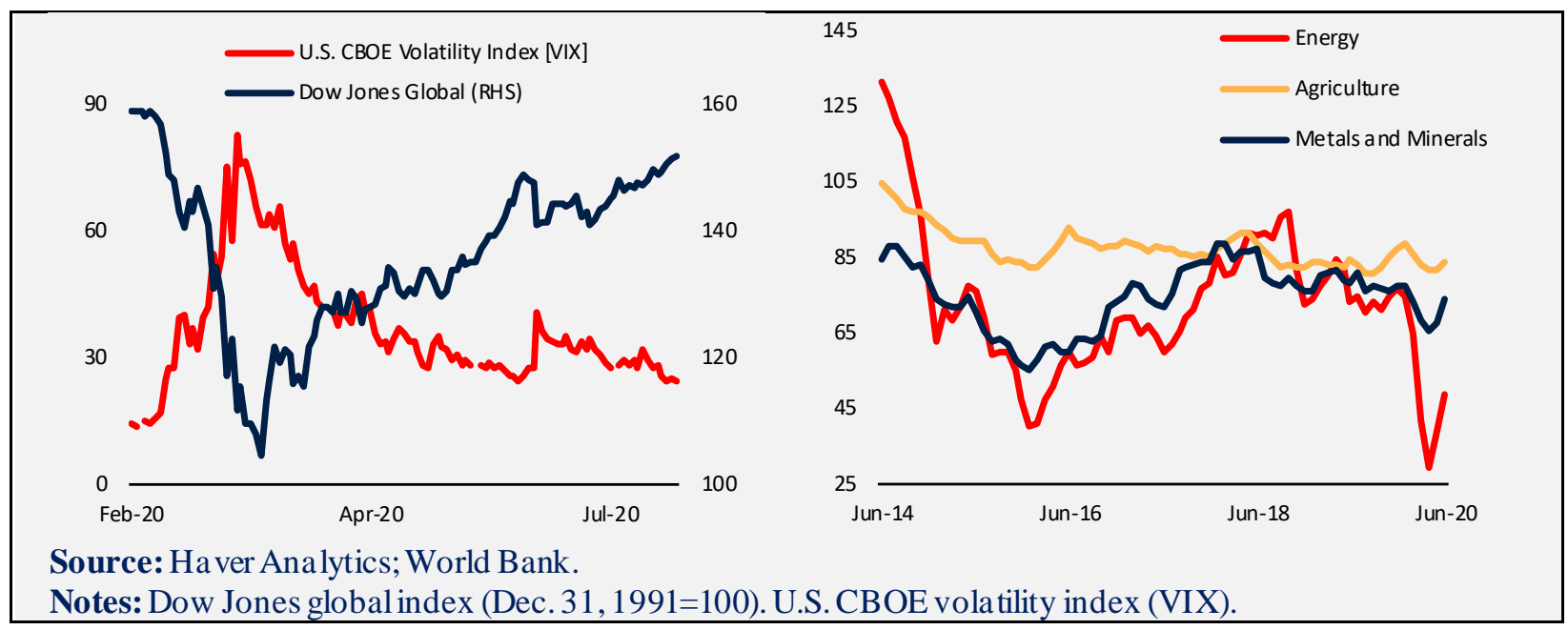

\section{Economic and Social Impacts}

\section{Covid-19 led to a deep contraction of GDP in the first quarter}

The outbreak has taken a significant toll on the Chinese economy. COVID-19 upended incipient economic momentum that was building after the Phase 1 of the China-U.S. trade deal was concluded in December 2019. This nascent recovery of manufacturing output, investment, trade, and growth in the last quarter of 2019, came to an abrupt halt in February when the COVID-19 outbreak triggered a combined supply and demand shock. GDP contracted by 6.8 percent y/y in 2020Q1. The contraction was broad based and led by industry, which fell 8.5 percent (Figure 5.A). Output in the service sector declined by 5.2 percent, while agricultural output dropped 3.8 percent.

\section{Figure 5. GDP growth}

\section{A. Sectoral composition}

(Contribution to growth, percentage points)

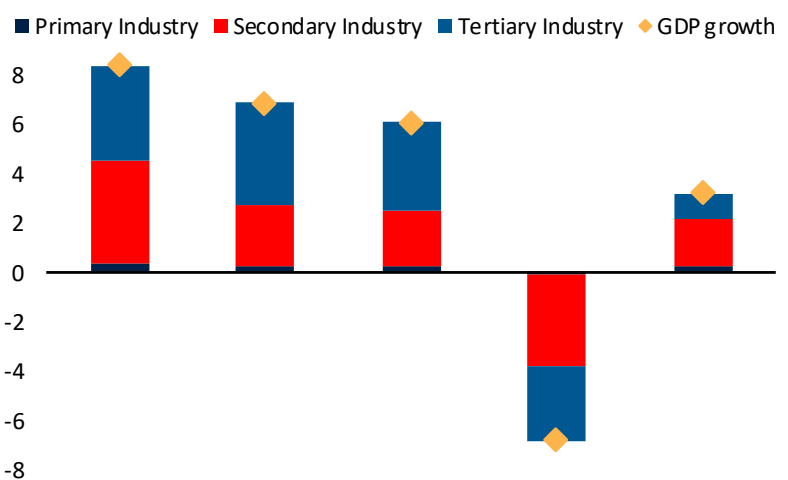

\section{B. GDP demand components \\ (Contribution to growth, percentage points)}

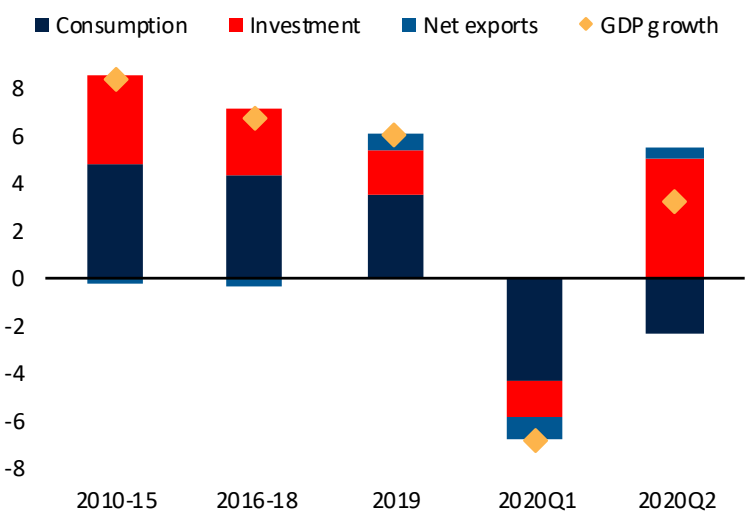

Source: Ha ver Analytics; NBS; World Bank.

COVID-19 hit private consumption particularly hard. The decline in consumption accounted for almost two-thirds of GDP contraction in 2020Q1 (Figure 5.B). Consumption growth dropped from 6.4 percent in 2019 to negative 7.5 percent in 2020Q1. Its contribution to growth declined to -4.4 percentage points y/y 
in 2020Q1, down from 3.5 percentage points last year. According to household survey data, the decline in household spending exceeded the decline in household incomes. Real household disposable income per capita fell by 3.9 percent y/y in 2020Q1, reflecting labor dislocations and wage pressures. Meanwhile, income losses, social distancing, and uncertainty associated with the COVID-19 outbreak caused real private consumption expenditures to fall by 12.5 percent. As a result, the saving rate of households continued to rise, from 36 percent in 2019Q1 to 41 percent in 2020Q1. ${ }^{4}$

\section{Box 2. E-commerce in times of COVID-19}

Widely available e-commerce options gave consumers continued access to products and services during the pandemic, especially during lockdowns. Even before COVID-19, China had one of the largest and fastest growing e-commerce markets in the world, with online sales of goods and services accounting for over 20 percent of total retail sales in 2019. E-commerce has spread from China's urban areas into its rural localities. Online consumption gained further prominence lately amid lockdowns, store closures, and a consumer reluctance to engage in face-to-face interactions with sales and service staff. According to a recent COVID-19 mobile survey conducted by McKinsey \& Company, some 74 percent of Chinese consumers bought additional groceries online during the COVID-19 outbreak. $^{5}$

Figure 6. Nominal growth in retail sales of goods

(y/ypercent)

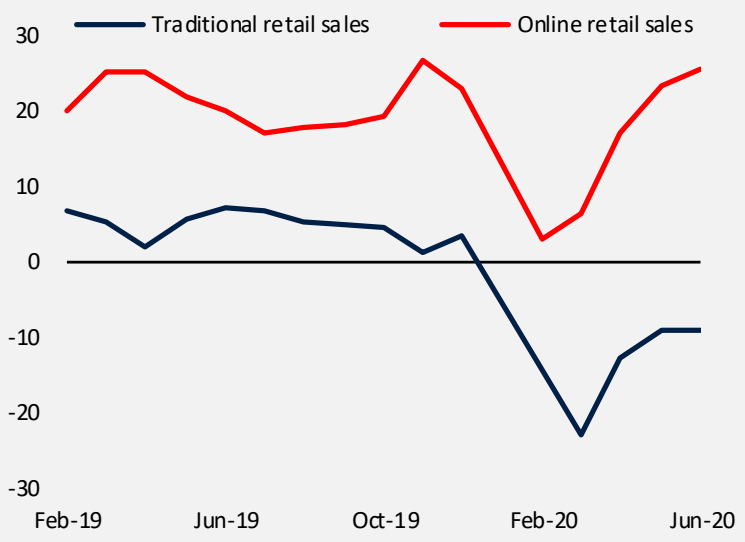

Source: NBS. Indeed, while traditional retail sales of consumer goods contracted by 17.9 percent $y / y$ in the first half of 2020 in nominal terms, online goods retail sales grew by 14.3 percent during the same period.

Investment, especially of the private sector, also plummeted. Overall, gross capital formation contributed -1.5 percentage points to GDP growth in the first quarter of 2020, compared to 1.1 percentage points during the same period last year. Private sector investment dropped by 24.4 percent y/y, compared to a 15 percent $y / y$ decline of investment by state-owned companies. Fixed asset investment in the manufacturing sector contracted the most (27.4 percent y/y decline), reflecting worsening business confidence and financial constraints, including plummeting revenue and profits. Infrastructure investment dropped by 18.5 percent $y / y$, largely because of significant delays in transportation projects and labor shortages. Property investment also fell by 11.5 percent $y / y$, amid slowing housing sales.

Major supply disruptions, due to factory closures, led to a significant plunge in ind ustrial production. Manufacturing output suffered the sharpest decline (10.2 percent $y / y)$, compared to mining ( -1.7 percent) and utilities (-5.2 percent). The combined shocks from a decline in domestic demand, inventory destocking, and disruptions in global value chains disproportionately affected the automobile (-26 percent), general equipment (-17.2 percent), and computer production subsectors (-13.8 percent). A sharp decline in infrastructure and property investment led to a steep 17.5 percent contraction in construction activity. Activity in upstream industries, especially ferrous metal smelting ( 0.5 percent) and crude coal production (-0.6 percent), held up better, as they were less affected by lockdown measures.

\footnotetext{
${ }^{4}$ The aggregate household saving rate is calculated by dividing household disposable income of households, net of household consumption, by household disposable income.

${ }^{5}$ See (McKinsey 2020)
} 
The COVID-19 shock severely hit services involving face-to-face interactions. Overall, output in the service sector declined by 5.2 percent y/y in 2020Q1. Sectors particularly hard hit by the abrupt drop in demand included hospitality and catering ( -35.3 percent), transportation (-14.0 percent), and traditional wholesale and retail trade (-17.8 percent). This was partly offset by the strong performance of online services - internet commerce, education, entertainment, healthcare, and financial intermediation (Box 2). In contrast to many other sectors, the financial sector expanded by 6 percent y/y in 2020Q1, helped by policy support, which led to accelerated credit growth and high stock market turnover.

Due to disruptions in production and distribution systems, agricultural production also contracted, but less than services and industry. China's pig, sheep, and beef production shrank by 29.1, 7.7, and 6.4 percent y/y respectively in 2020Q1, likely reflecting labor shortages, especially in feed supply, and logistical problems faced by agricultural producers. Poultry meat production growth also declined sharply, from 10.2 percent $y / y$ in 2019Q4 to 1.1 percent in 2020Q1, partly because of restrictions on the transportation of live poultry during disease outbreaks. Delays in the supply of production inputs such as seeds, fertilizer, pesticides, and farm labor led to some disruptions in the planting of early spring crops such as rice, maize, and vegetables. However, crop farming was less affected overall, with output growth slowing to $3.5 \mathrm{y} / \mathrm{y}$ in $2020 \mathrm{Q} 1$ from 4.3 percent in 2019Q4.

\section{Activity has started to rebound, but the recovery remains uneven}

As the impact of the pandemic began to recede, China started to roll back restrictions, allowing economic activity to resume from late February. The reopening was accompanied by measures to reduce risks of re-emerging outbreaks, including large scale testing, mobile-phone-based contract tracing, land border closures, quarantine requirements for international travelers, social distancing in public places, and the widespread use of masks, and protective equipment.

Following a sharp contraction in the first quarter, China's economy returned to growth in the second quarter. GDP expanded by 3.2 percent $y / y$ in 2020Q2, bringing the contraction in the first half of 2020 to 1.6 percent $y / y$. The economy recovered at an uneven pace with industrial production and infrastructure investment normalizing much faster than services, consumption and private investment. On the production side, the rebound was led by industry, which expanded 4.7 percent y/y in Q2. In contrast, growth in the service sector remained subdued at 1.9 percent $y / y$, reflecting remaining restrictions on service activity and lingering behavioral impacts. On the demand side, the data points to the underlying fragility of the recovery. Growth was driven by public investment and exports, while private investment and consumption continued to underperform. The contribution of net exports to growth turned positive $(0.5 \mathrm{pp})$ in $\mathrm{Q} 2$, due largely to declining imports as well as stronger than expected exports driven by a surge in shipments of medical equipment and electronics (see the next section for the details).

Investment growth, in particular in the state sector, rebounded sharply in Q2 supported by stepped up stimulus measures. Gross capital formation contributed a full 5.0 percentage points to Q2 growth. Fixed asset investment data suggest the rebound was mainly driven by infrastructure and real estate investment amid stimulus spending and rising housing sales and prices. In contrast, manufacturing investment contracted by 4.7 percent $y / y$ in $\mathrm{Q} 2$, as strained corporate revenue and heightened uncertainty restrained the pace of private investment recovery (Figure 7.C). Notably, investment by state-owned companies rebounded to 9.9 percent $y / y$, while private sector investment remained sluggish, dropping by 7.1 percent y/y in Q2 (Figure 7.D). 
Figure 7. Economic activity

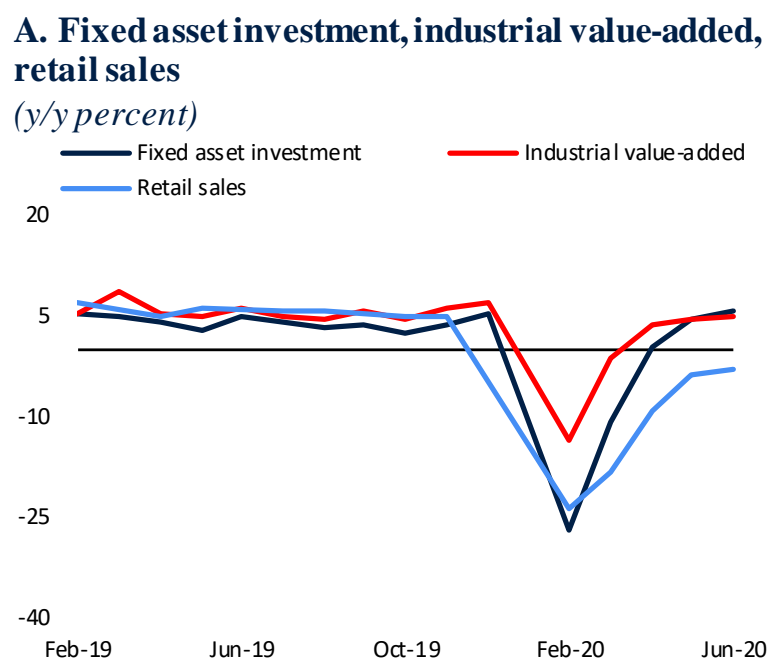

C. Real fixed asset investment growth by sector (y/y percent, in real terms)
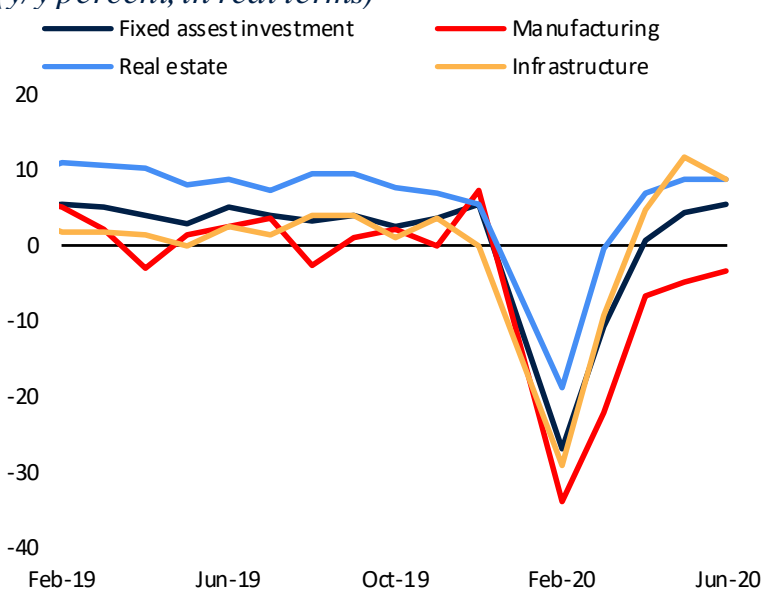

\section{B. Real growth of industrial value-added (y/y percent, by product and product group)}

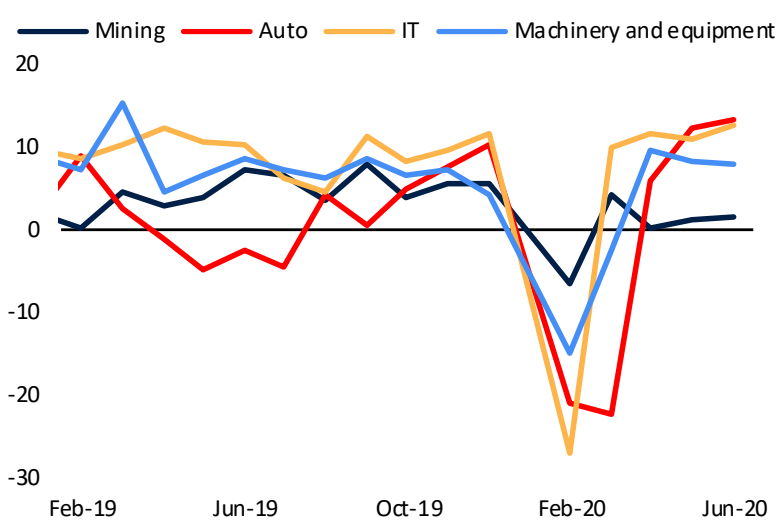

D. Real fixed asset investment growth by ownership (y/y percent, in real terms)
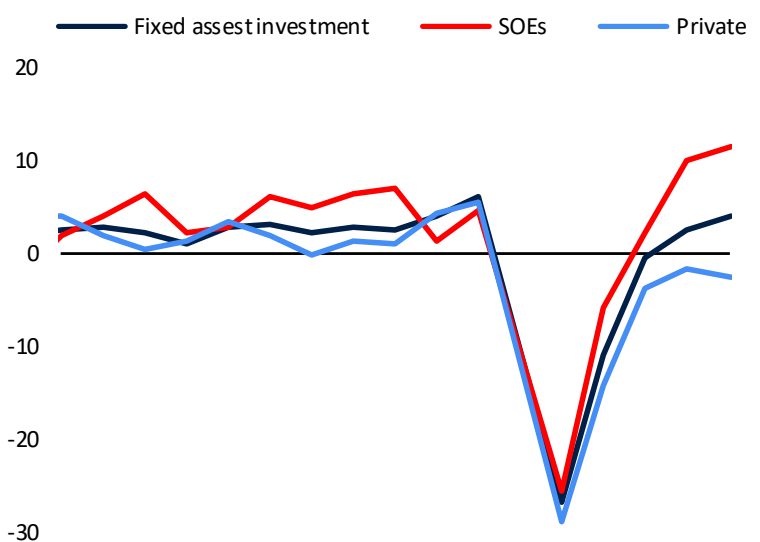

Feb-19 Jun-19 Oct-19 Feb-20 Jun-20

Source: World Bank staff estimates based on data from CEIC and China National Bureau of Statistics.

Note: The published fixed a sset investment data represents investment in urban areas.

Consumption continued to underperform, highlighting a continued weakness in domestic demand. Consumption fell by 4.3 percent y/y in Q2. Given the muted recovery in wages, increases in household disposable income remained subdued in Q2. As a result, consumption expenditures per capita continued to fall in the second quarter ( 5.6 percent $y / y)$ albeit at a smaller pace than in the previous quarter (12.5 percent $\mathrm{y} / \mathrm{y})$. Meanwhile, retail sales a key indicator of consumption, contracted 5.2 percent $y / y$ in Q2, underscoring persistent domestic demand weakness, as elevated unemployment levels, lower household incomes, and remaining social distancing measures continue to weigh heavily on consumer spending.

Industrial production bounced back fast in Q2 as supply side constraints eased. Manufacturing output rose by 5.1 percent y/y in Q2, outpacing recovery in mining (1.0 percent y/y) and utilities (3.1 percent y/y). Industrial value-added growth rose across sectors, with auto, information technology and machinery equipment rebounding the most. In contrast, activity in some traditional industrial sectors, such as textile and chemical, improved by a smaller margin. Construction rose strongly to 7.8 percent $y / y$ in Q2, largely due to accelerated infrastructure investment on higher policy support. 
The recovery in services has been uneven across sectors. On the positive side, growth in IT and financial services stayed strong at 15.7 and 7.2 percent y/y in Q2, respectively. Growth of the real estate sector accelerated to pre-COVID-19 level of 4.1 percent $y / y$ in $Q 2$ from -6.1 percent $y / y$ in Q1 amid the recovery in the housing market. In contrast, transportation and traditional wholesale and retail trade which were hit hard in Q1 recovered more modestly to 1.7 and 1.2 percent y/y in Q2, respectively, while growth in accommodation and catering remained in deep negative territory at -18.0 percent $y / y$. High frequency indicators show that activity in transportation, catering, and entertainment sectors has been recovering but still stands below its pre-outbreak level, reflecting consumer reluctance to engage in activities involving face-to-face interactions. Subway passenger volume in six major cities remains at around 90 percent of preCOVID 19 levels. Domestic flights are about 15 percent below their typical pre-COVID-19 levels. While most restaurants have resumed operations, dining expenditures, including for takeout, remain about 10 percent below their pre-outbreak levels.

\section{Figure 8. Consumer-facing services have recovered gradually}

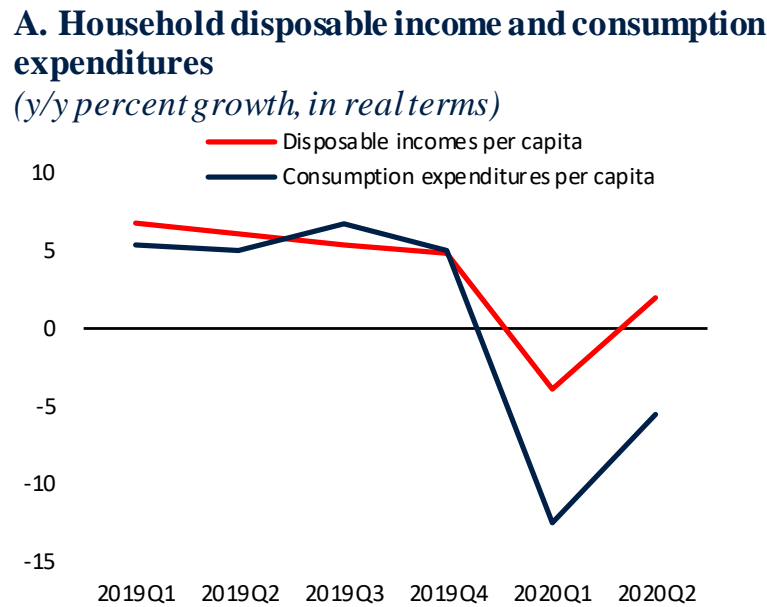

C. Domestic flights

(Number offlights, thousands, 7-daymoving avg)

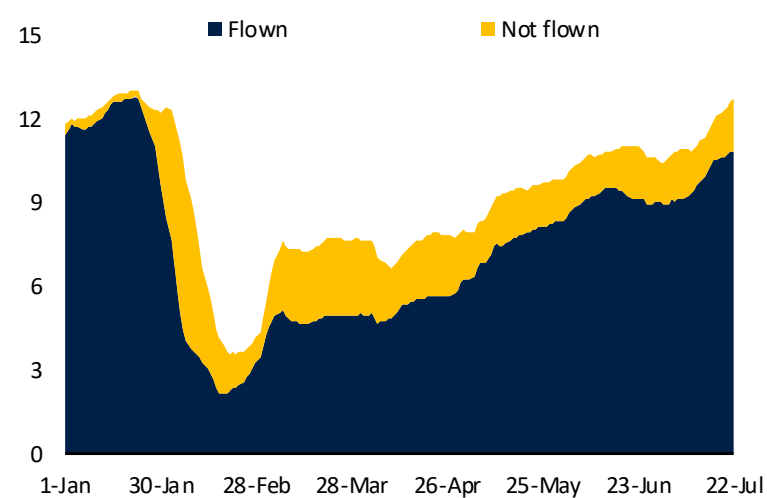

B. Restaurant services (y/y percent growth, 7-day moving avg)

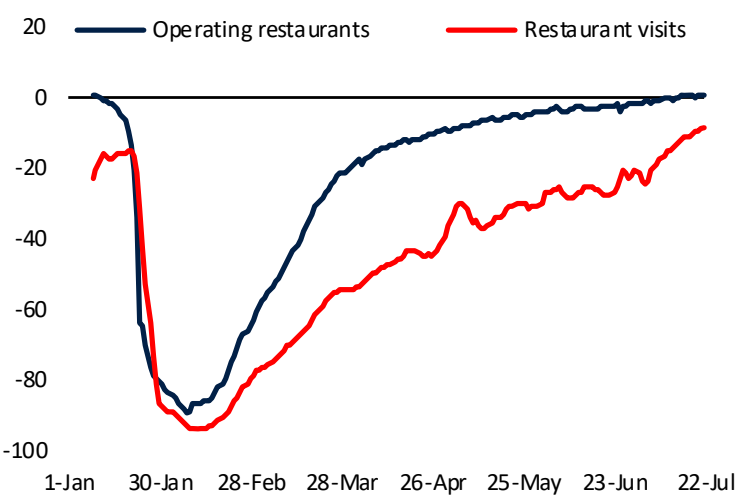

D. Daily subway passenger volume of six major cities

(Volume, million passengers, 7-day moving avg)

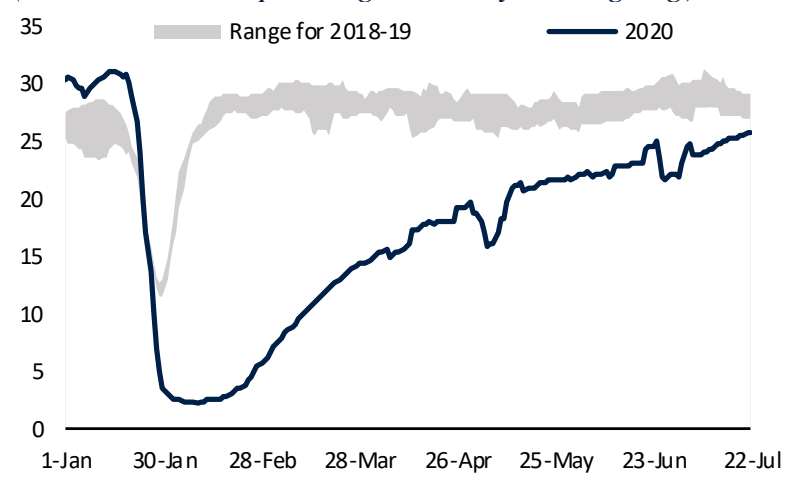

Source: NBS; Cirium coronaviru s aviation impact dataset; Hualala website, WIND database. World Bank.

Note: B. Hualala is a n online information management system that tracks about 10 percentofChina's total catering transactions. D. Subway passenger volume in six major cities in China, including Shanghai, Guangzhou, Chengdu, Nanjing, Suzhou and Zhengzhou.

Agricultural production recovered to pre-Covid-19 level in the second quarter reflecting easing of labor shortages and logistical constraints. Overall output in the agricultural sector expanded by 3.3 percent $y / y /$ in Q2. The contraction in pork production narrowed to 4.6 percent $y / y$ in Q2 from 29.1 percent 
$y / y$ in Q1, signaling a gradual recovery from the dual effects of COVID-19 and African swine fever. China's beef, sheep, and poultry meat production growth rebounded to $0.8,3.1$ and 13.9 percent y/y in Q2 from 6.4, -7.7, and 1.1 percent in Q1, respectively, reflecting easing of labor shortages and logistical difficulties faced by agricultural producers. The output growth of crop farming, which was less affected by the COVID19 outbreak, slightly increased to 3.9 percent y/y in Q2 from 3.5 percent y/y in Q1.

\section{External trade activity has been volatile}

Trade flows have been volatile amid the pandemic-related disruptions. The stop-and-go pattern of activity in China and other economies, caused by the asynchronous imposition of lockdowns and restrictions, disruptions in transportation and supply chains, and plummeting global demand, all have contributed to the volatility. The pandemic-related disruptions have affected all trade flows. Both goods exports and imports contracted sharply in February, following the imposition of lockdowns in China. The resumption of production in China in late February led to a sharp rebound of export growth in March (Figure 9). The contraction of volumes of goods imports, which also reflected a drawdown of large stockpiles accumulated in December in the aftermath of the Phase 1 deal, also eased (Figure 9.A). However, the contraction of goods import values has deepened, reflecting plummeting commodity prices amid collapse in global demand (Box 1; Figures 4.B and 9.B).

\section{Figure 9. Trade flows}
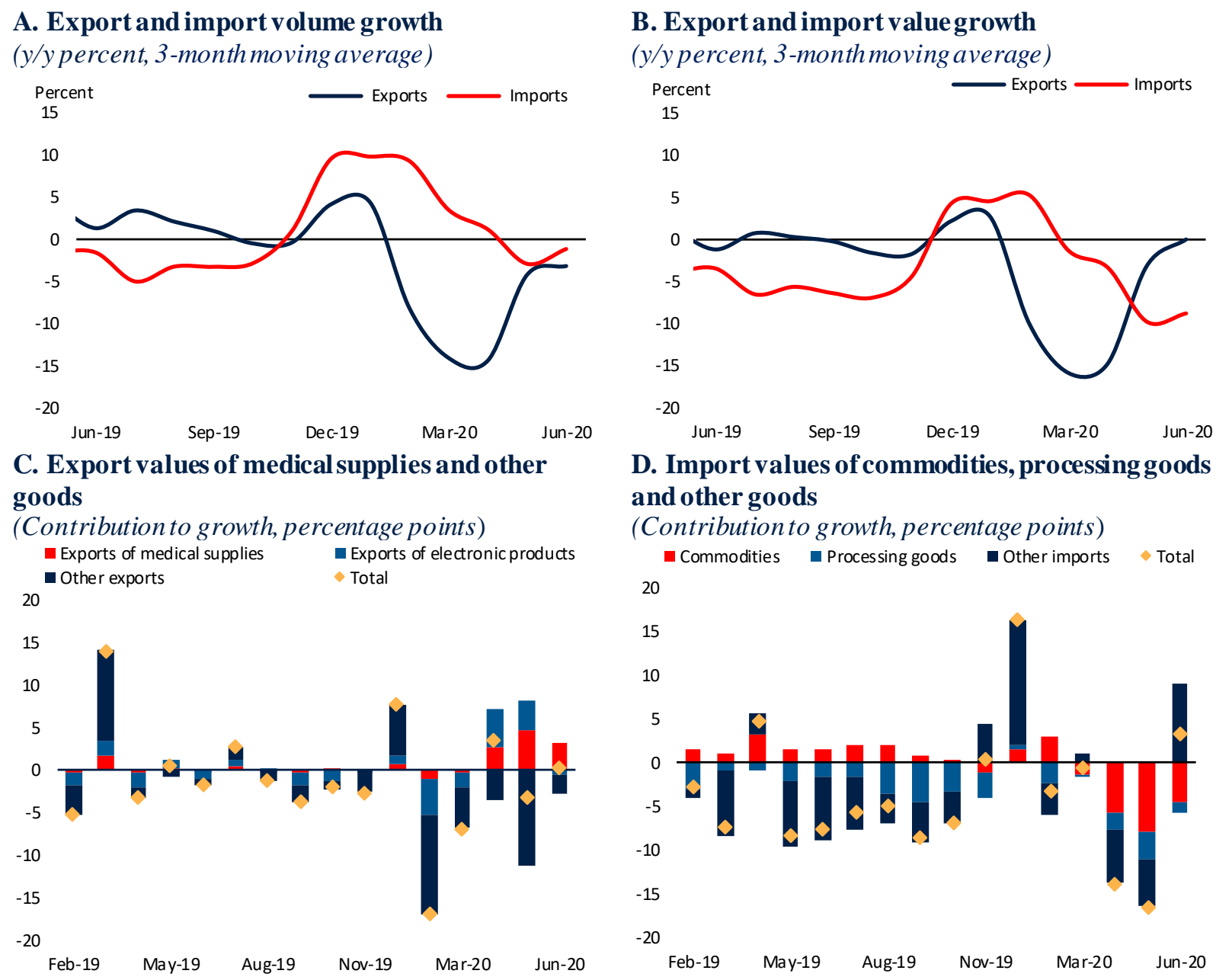

D. Import values of commodities, processing goods and other goods

(Contribution to growth, percentage points)

- Commodities - Processing goods - Other imports $\diamond$ Total

20

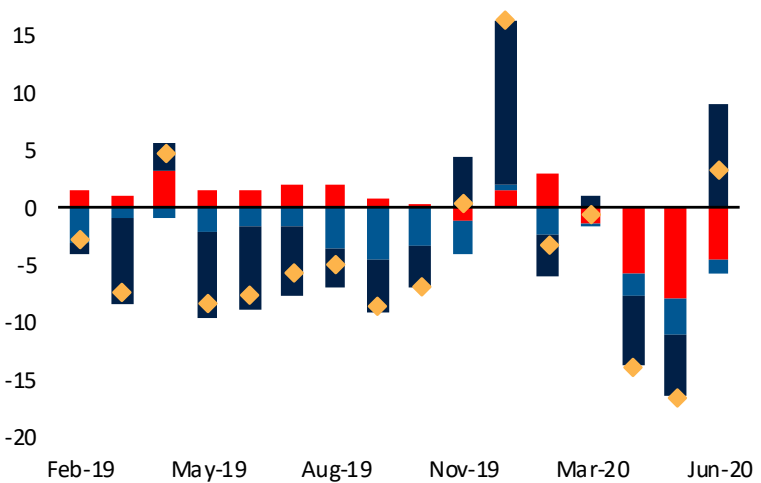




\section{E. Export value growth by region \\ (3-month moving average)}

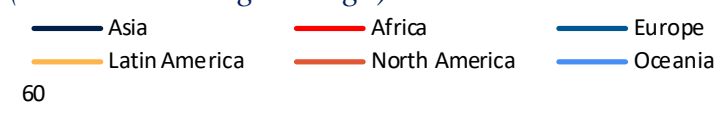

40

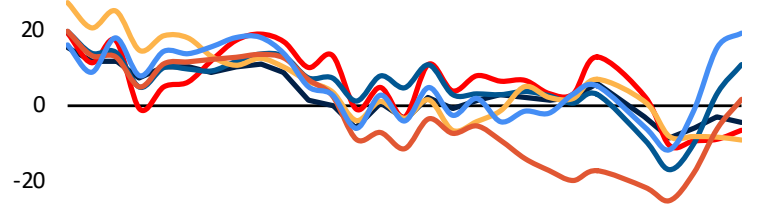

$-40$

$-60$

Feb-18 Sep-18 Apr-19 Nov-19 Jun-20
F. Import value growth by region

(3-month moving average)

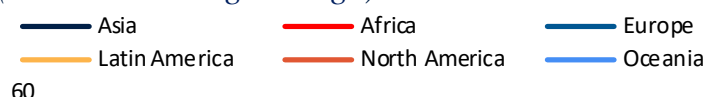

60

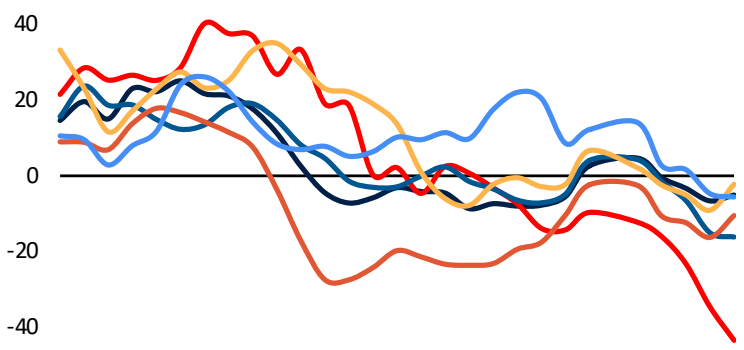

$-60$

$\begin{array}{llll}\text { Feb-18 } & \text { Sep-18 } & \text { Apr-19 } & \text { Nov-19 }\end{array}$

Jun-20

Source: CEIC; China Customs; China Na tional Bureau of Statistics; World Bank.

Note: Electronic products include high-tech products and integrated electronic circuitry. Medical supplies include medical or surgical apparatus and textile y arn and fabric that are used for mask production. Commodities include metal ore, coal, crude oil, refined petroleum products, and natural gas; processing goods includes processing and assembling goods and processing with imported material.

The global spread of the virus sparked a surge in demand for essential medical supplies, and the need for electronic goods jumped in response to the massive shift to remote work. Both trends boosted demand for Chinese exports. This surge was offset by a plunging demand for exports of other goods, as economic activity came to a standstill in large parts of the world, resulting in an 8.3 percent y/y contraction in the total volume of goods exports in China in $2020 \mathrm{H} 1$. The decline was broad-based, led by a 11.6 percent y/y contraction of export volumes to the United States (Box 3).

\section{Box 3. Recent developments in China-U.S. bilateral trade}

Under the interim trade agreement between China and the United States, concluded in December 2019, China has committed to purchase U.S. goods and services in 2020 and 2021 worth a combined \$200 billion above 2017 levels ( 1.5 percent of China's GDP). The annual target for goods and services imports is $\$ 214$ billion and $\$ 260$ billion, or 1.6 and 2.1 percent of China's GDP, for 2020 and 2021, respectively. By the end of June, China had reached about one-fourth of its annual goods purchase commitment.

Bilateral trade between China and the United States continued to weaken in the first half of 2020. China's goods export value to the United States dropped by 11.1 percent y/y in $2020 \mathrm{H} 1$, following a 12.9 percent contraction in 2019. China's goods import value from the United States dropped by 4.4 percent y/y during this period, but the pace of contraction slowed from 21.3 percent in 2019 . China recorded a $\$ 120.9$ billion (0.8 percent of China's GDP) goods trade surplus with the United States in the first half of 2020, down from $\$ 140.4$ billion (1.0 percent of China GDP) during the same period last year (Figure 10.C).

Trade and investment remain as major points of contention, especially in sensitive sectors, including semiconductors and other technological products, against the backdrop of remaining concerns about the protection of intellectual property rights and market access, as well as cyber-security. Additional steps have been taken by U.S. authorities to tighten restrictions in the trade and investment relationship with China. As of June, more than 300 companies and institutions in China were included in the so-called entity list, which is subject to specific trade and investment restrictions. Increasingly restricted access to critical technology imports, including semi-conductors, could weigh on China's productivity growth and harm potential growth. 
Figure 10. China-U.S. bilateral trade

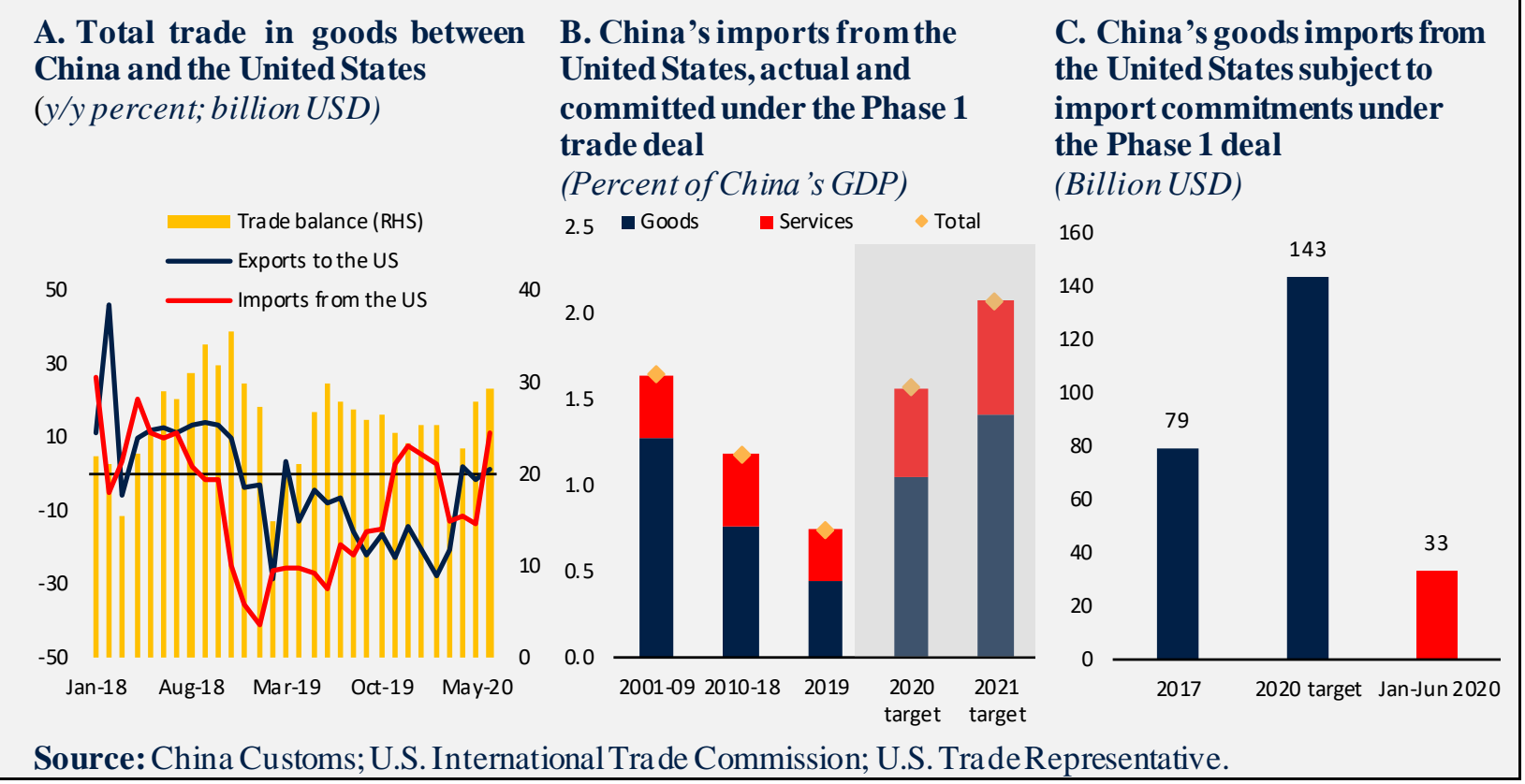

Despite temporary disruptions caused by COVID-19, preliminary trade data confirms that global supply chains are unlikely to change overnight. The progressive spread of COVID-19 and lockdown measures across countries and regions has led to production disruptions and border delays, propagating ripple effects through GVC linkages. In a recent survey, more than two-thirds of multinational investors in developing countries reported disruptions in supply chains, declines in revenues, and decreases in production as a result of COVID-19. ${ }^{6}$ However, despite the disruptions, preliminary trade data shows that exports and imports in sectors with strong backward and forward linkages have been less affected by the disruptions due to COVID-19. For example, the computer and electronics sector, which represents the largest share of Chinese trade values and has strong backward linkages, remained relatively resilient in terms of both exports and imports (Box 4).

\section{Box 4. Impact of the pandemic on $\mathrm{GVCs}^{7}$}

China's manufacturing sector is integrated into global value chains, exposing it to potential ripple effects from supply disruptions propagated through GVC linkages. China's manufacturing sector exports depend on imports of components, mostly from regional economies, including Japan, the Republic of Korea, and Taiwan, China (World Bank 2020h; Figure 11).

Integration in global value chains appears to be correlated with a lower decline in the exports and imports of a sector. The strength of sector-specific cross border linkages in China, a proxy of integration into global supply chains, appears to have been positively correlated with the sector-specific exports and imports growth during the first four months of the year that data are available (Figure 12). Sectors with strong backward and forward linkages, such as electronics performed relatively better than other exports,

\footnotetext{
${ }^{6}$ See (World Bank. 2020g).

${ }^{7}$ Prepared based on input written by Ergys Islamaj, Ileana Cristina Constantinescu, and Woori Lee, with guidance from Mic hael Ferrantino, Aaditya Mattoo and Michele Ruta.
} 
partly reflecting the greater importance of source markets in the region, where countries such as Korea and Taiwan, China had relatively limited and short-lived lockdowns and disruptions, and partly the difficulties associated with a reconfiguration of global value chains in the short term.

\section{Figure 11. Backward linkages in China}
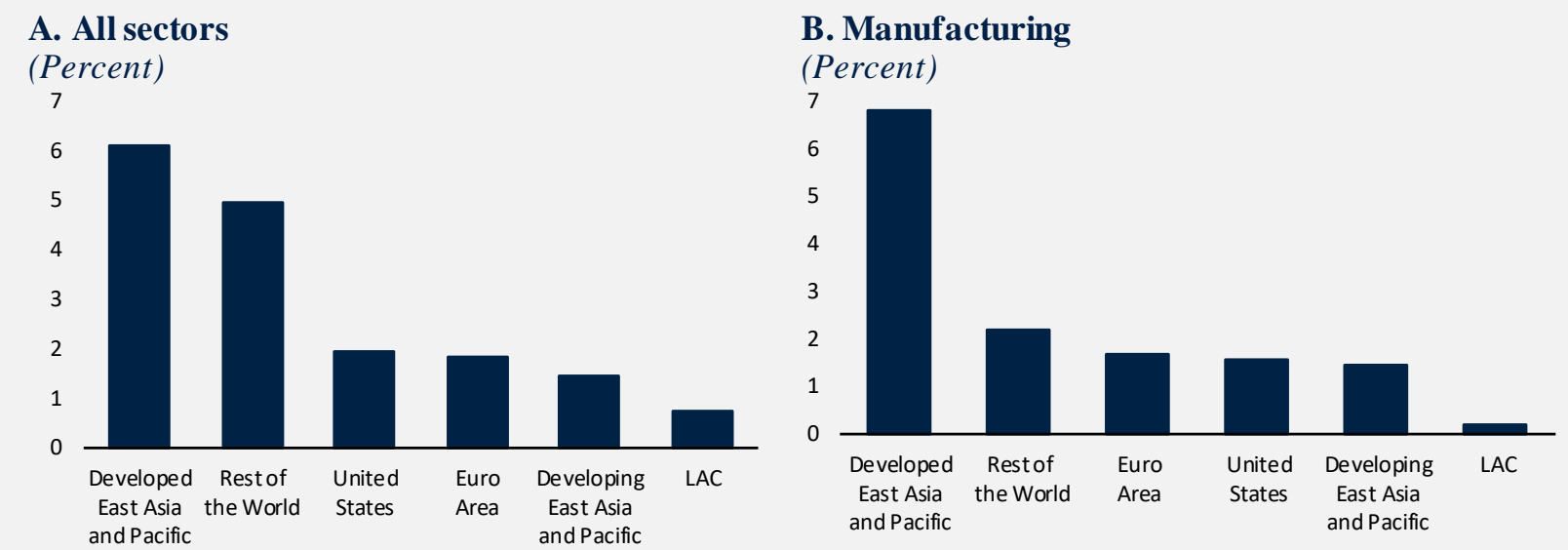

Figure 12. China's sectoral trade and GVC intensity (y/y percent, percent, Jan-May 2020)

\section{A. Exports: backward linkages}

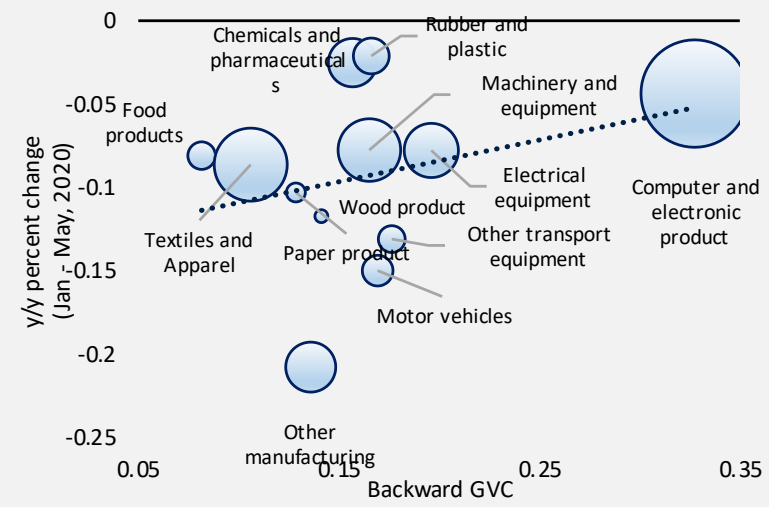

C. Imports: backward linkages

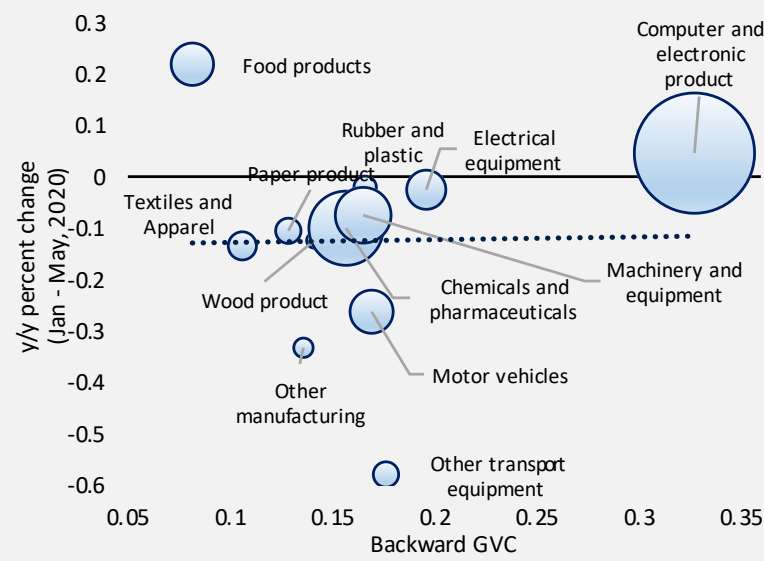

B. Exports: forward linkages

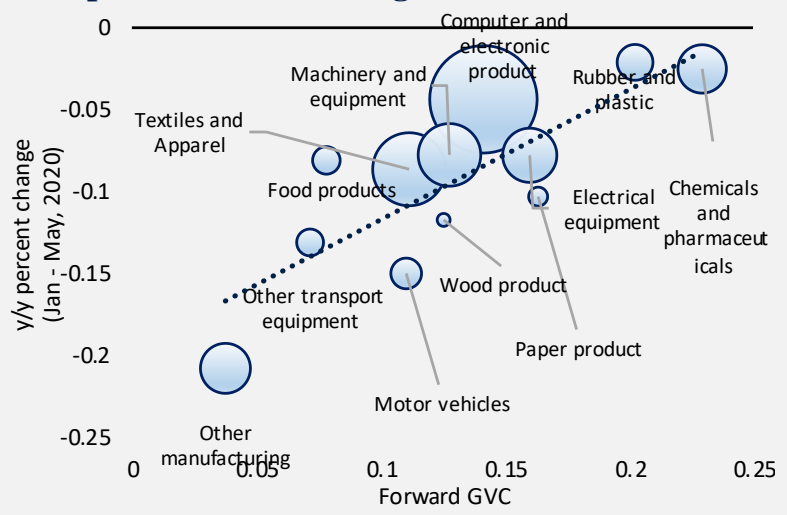

D. Imports: forward linkages

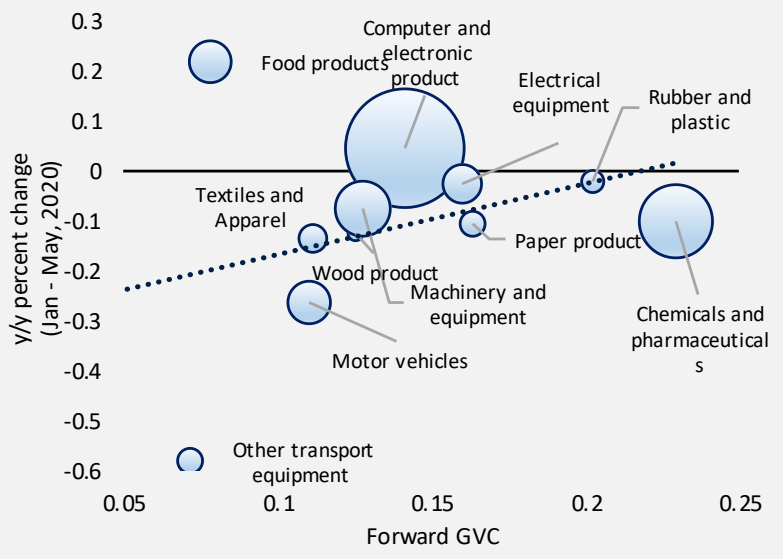

Source: World Bank staff estimates using official da ta from China customs and WDR database. Note: The size of the circles represents sectoral trade values in 2019. 
The longer-term consequences of the COVID-19 crisis on GVCs, however, remain uncertain. The stickiness of the GVC relationships tends to dominate in the short-term, explaining the resilience of GVC trade. In the longer term, however, the COVID shock and ongoing geopolitical tensions may trigger some reconfiguration of global supply chains and trading patterns, as firms and governments may seek to diversify supply capacities and reduce dependence on single source markets, especially in sensitive areas such medical supplies. ${ }^{8}$

COVID-19 may accelerate some existing trends. First, the gradual shift away from China of some manufacturing activity because of increasing real wages is likely to accelerate in response to COVID-19 shock. This shift in production may be driven by the tendency of importers to reduce excessive dependence on any single source in the aftermath of a shock. Second, globalization of services is likely to be boosted by the rapid investments in digital equipment and literacy in response to COVID-19. This could bring new opportunities for China, which it can exploit by improving relevant skills and increasing openness to trade and investment in services.

China's import bill contracted, reflecting subdued domestic demand, global trade disruptions, and lower commodity prices, which benefit China as a net importer of energy. The total volume of goods imports is estimated to have expanded by 0.2 percent $y / y$ in 2020Q1, reflecting a cyclical surge related to the restocking of inventories that started at the end of last year. Since then, imports of goods have decelerated gradually amid a major collapse in global activity, disruptions in transportation and supply chains, and weakness in domestic demand in the wake of the outbreak. The contraction of imports was much larger in value terms, reflecting a plunge in commodity prices. Import values of raw materialswhich represent about 20 percent of China's import bill — dropped by 27.6 percent y/y in Q2, while imports of other goods declined by 4.1 percent.

After posting a shallow deficit in 2020Q1, the external current account moved back into surplus in Q2. The goods trade surplus dropped to $\$ 26.4$ billion ( 0.2 percent of GDP) in 2020Q1 from $\$ 75.7$ billion ( 0.5 percent of GDP) during the same period last year, resulting from a sharp decline in goods exports amid domestic supply and transport disruptions and the recovery of imports after the phase 1 trade deal. In contrast, the service trade deficit narrowed in 2020Q1, reflecting a sharp decline in outbound international tourism affected by travel restrictions in the wake of the pandemic. The current account returned to surplus in 2020Q2. The goods trade surplus widened to \$154.7 billion in Q2 (1.1 percent of GDP) reflecting the combined effect of the higher value of medical supply and electronic equipment exports and the sharply lower value of imports, due to lower commodity prices.

China's capital account has been relatively resilient, in the midst of a general pullback of capital from emerging markets. The capital and financial accounts recorded a small deficit of around 0.1 percent of GDP in 2020Q1. Amid heightened uncertainty, net Foreign Direct Investment (FDI) almost halved to \$16.3 billion (0.1 percent of GDP) in 2020Q1, with lower outflows partly offsetting a decline in inflows (Figure 13.B). Net portfolio investment suffered significant outflows of $\$ 53.2$ billion ( 0.4 percent of GDP in 2020Q1), a reversal of earlier inflows, driven largely by lower equity inflows in line with the general global asset reallocation away from risky assets during that period. Net errors and omissions turned positive in 2020Q1, suggesting informal capital flight was limited. Foreign Exchange (FX) reserves declined slightly, by $\$ 25.1$ billion ( 0.2 percent of GDP) in 2020Q1, largely due to valuation effects. In 2020Q2, FX reserves increased by $\$ 51.7$ billion ( 0.4 percent of GDP). China's external position remains strong, with FX reserves estimated at $\$ 3.1$ trillion (the equivalent of around 17 months of imports) by the end of June.

${ }^{8}$ See (Freund, C., A. Mattoo, A. Mulabdic, M. Ruta. 2020). 
Figure 13. Balance of Payments

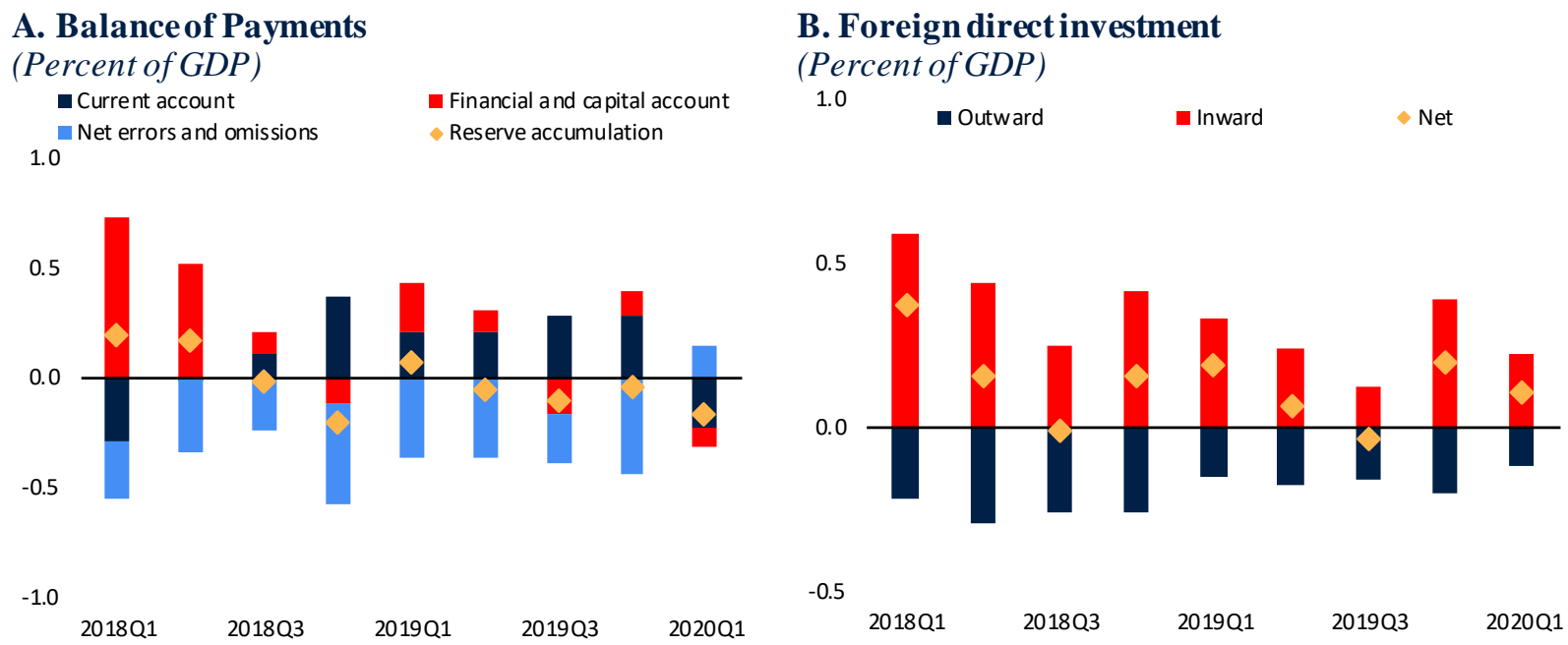

Source: Ha ver analytics; State Administration of Foreign Exchange (SAFE)

Global policy uncertainty contributed to financial market volatility and exchange rate pressures in the first half of 2020. At the start of 2020, China's financial markets had recovered most of the heavy losses incurred in 2018-19, but volatility returned in January following the outbreak. The Shanghai Composite Index lost about 7 percent between late January and March (Figure 14.A). The Renminbi depreciated by more than 3 percent against the dollar during the same period, and breached the RMB 7 per dollar threshold for the second time since 2008 (Figure 14.B). Unprecedented monetary policy support globally, and monetary policy actions undertaken in China, have helped stabilize financial markets and reduce pressures on asset prices, with equity indices rising strongly since April and reached a five-year high recently, amid continued elevated volatility. The Renminbi (both onshore and offshore) also showed an upward trend starting from early June, propelled partly by overseas funds looking for higher returns in Chinese assets amid improved market expectations.

\section{Figure 14. Asset prices}
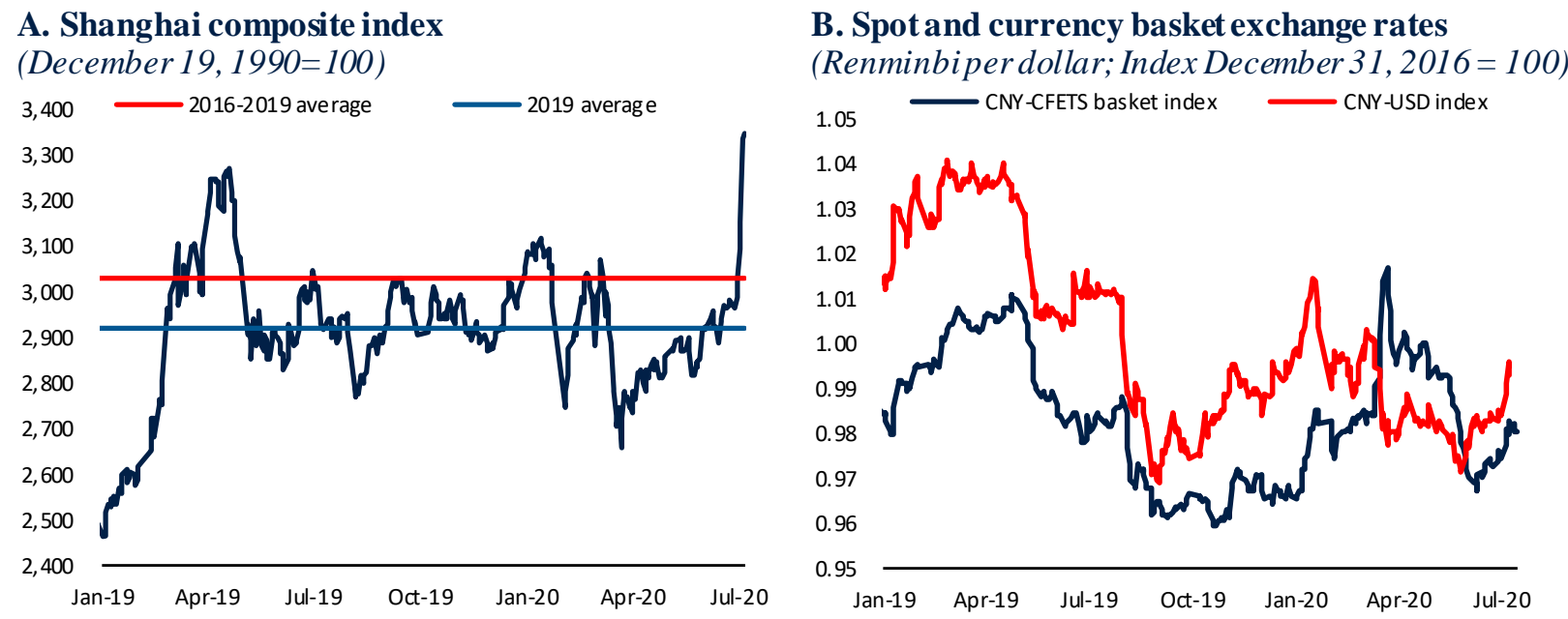

Source: Shanghai Stock Exchange; SAFE; World Bank. 


\section{Inflation has eased}

Consumer price inflation has moderated, reflecting lower energy and food prices and weak domestic demand. After peaking at 5.4 percent $y / y$ in January 2020, the headline CPI inflation decelerated to 3.5 percent on average in February-June. Energy prices dropped by 15.7 percent y/y and food prices rose by 15.3 percent $y / y$, during the same period, compared to a 7.2 and 20.6 percent increase in January (Figure 15.A). Core inflation, excluding food and energy prices, edged down to an average of 1.1 percent y/y in February-June from 1.5 percent in January, reflecting weak domestic demand amid the lingering impact of the Covid-19 outbreak (Figure 15.B).

Producer prices have continued to fall, reflectingsharply lower prices of raw materials. Producer price inflation (PPI) fell by 2.3 percent y/y on average in February-June compared to 0.1 percent growth in January (Figure 15.C). The drop mirrored lower producer prices of raw materials, which were down by 6.9 percent $y / y$ on average in February-June compared to a 0.8 percent increase in January. PPI inflation for producer goods also declined to an average of -3.4 percent y/y in February-June from -0.4 percent y/y in January, pointing to subdued manufacturing activity. Sluggish producer prices have weighed on industrial profits, which fell by 19.3 percent $y / y$ in the first five months of 2020.

Housing price growth has moderated across all three city tiers. Housing price growth in newly constructed residential buildings in all three tiers slowed to an average of 3.3, 5.9, and 5.4 percent y/y in first half of 2020 from 4.2, 11.9, and 11.2 percent in 2019, respectively (Figure 15.D). Slower housing price growth was associated with a decline in housing sale transactions during the lockdown period and a rise in the household propensity to save amid higher uncertainty.

\section{Figure 15. Inflation and housing prices}
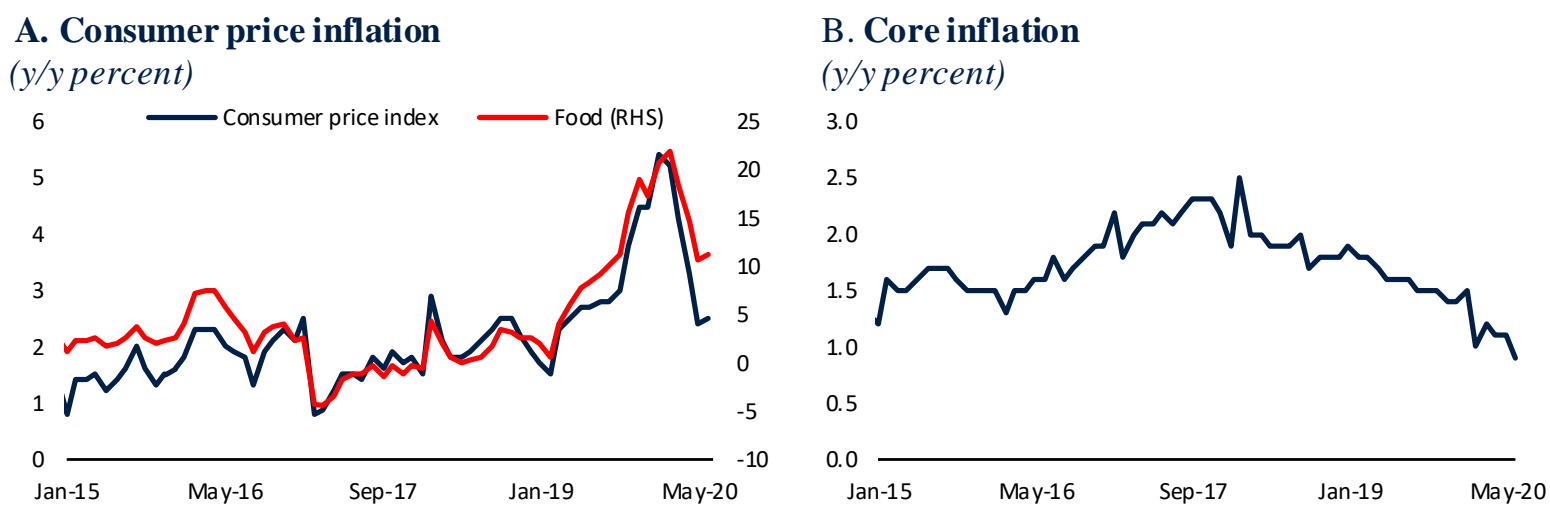

C. Producer price inflation

(y/ypercent)

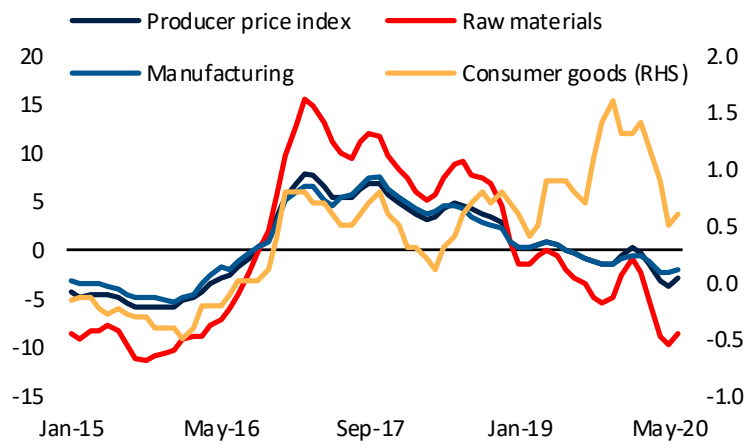

D. Housing price growth in 70 cities $(y / y$ percent $)$

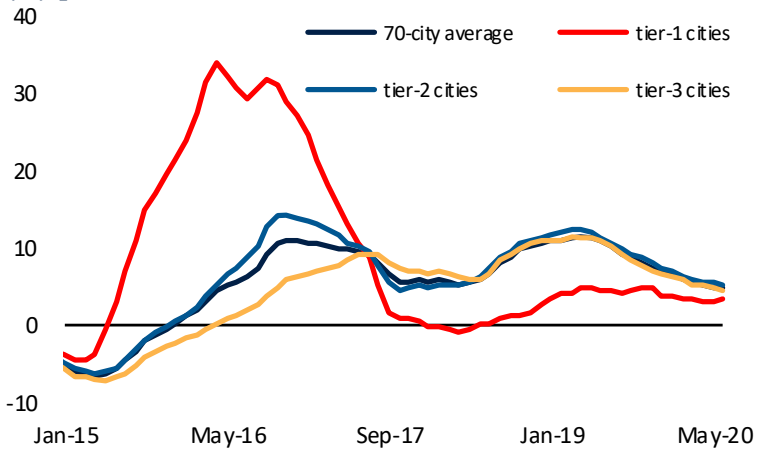

Source: NBS; World Bank. 


\section{Labor market disruptions and income losses have taken an economic toll on households}

The labor market impacts of COVID-19 in China have been significant, with surging unemployment and significant labor dislocation. The official surveyed urban unemployment rate, a key monthly unemployment indicator, jumped from 5.3 percent in January to 6.2 percent in February. As economic activity started to resume, it dropped slightly to 5.9 percent in March. According to this relatively narrow definition, which undercounts migrant unemployment, close to 26 million workers lost their jobs. In addition, an estimated 76 million workers were employed but were not working in March, accounting for 17.2 percent of total urban labor force ${ }^{9}$. The official surveyed urban unemployment rate remained elevated at 5.7 percent in June, suggesting persistent labor market pressure.

Labor market disruptions have disproportionately affected informal workers and migrant laborers. Informal workers and the non-agriculture self-employed are disproportionately concentrated in sectors experiencing the largest impact, such as construction, hotel and catering, and wholesale and retail trade. Lacking standard labor protections and access to benefits such as unemployment insurance, they are more vulnerable to losing their earnings if there is a renewed fall in economic activity. Migrants, who represent 30 percent of the total labor force in urban areas, are also disproportionally concentrated in those sectors highly affected by COVID-19 shock. In addition, migrant workers have been severely affected by the lockdown. The outbreak coincided with the celebration of the Lunar New Year, when many migrants had left their places of work to visit their families and were unable to return to work for a substantial period to time. Data indicate that three months after the Lunar New Year, around 20 percent of the migrants had still not returned to Tier-1 cities such as Beijing, Guangzhou, Shanghai, and Shenzhen. This contrasts with the pattern seen in 2019, in which more than 90 percent of migrants had returned to these cities 15 days after the Lunar New Year. A NBS survey found that the number of "go-out" migrant workers dropped sharply, from 174 million in December 2019 to 123 million in February 2020. While most migrant workers have returned to work by the end of June, wage pressures persist. Average monthly income of migrant workers was still down 6.7 percent y/y in 2020Q2 (Figure 16).

The crisis has revealed big gaps and institutional barriers in China's social protection systems, especially the limited coverage of migrant workers. Coverage of social safety nets is especially limited for the vulnerable, such as migrant and informal workers, which exposed them to COVID-induced job and income losses. The authorities have reacted by temporarily expanding coverage and benefit levels (part 2 of this report). Nonetheless, the crisis has highlighted underlying systemic gaps. For instance, it is estimated only 17 percent of migrant workers were covered by the unemployment insurance scheme in 2017 . Besides, only 22 percent of migrant workers participated in the country's urban workers' medical insurance and pension schemes (Figure 16.B). China's household registration system (hukou), which ties service access and social security benefits to the place of registration rather than the place of employment, is one institutional barrier for migrant and informal workers to participate in social assistance programs. In addition, the coverage of China's major social assistance programs (Dibao, Tekun, and temporary assistance) is relatively low, with only 56.7 million or about 4.1 percent of the total population registered as beneficiaries. Moreover, the benefits under this program are also relatively low. ${ }^{10} \mathrm{~A}$ more detailed discussion of the social and distributional impacts of the COVID shock and policy options to mitigate them is presented in chapter VI of this report.

\footnotetext{
${ }^{9}$ See (National Bureau of Statistics China. 2020).

${ }^{10}$ Among them, 8.6 million and 34.6 million benefited from urban Dibao and rural Dibao, respectively. Tekun beneficiaries amounted to 4.4 million and the remaining 9.2 million were beneficiaries of the temporary assistance program.
} 
Figure 16. Migrant workers

A. Active migrant workers and their income growth (Million people; y/y growth, income in nominalterms)

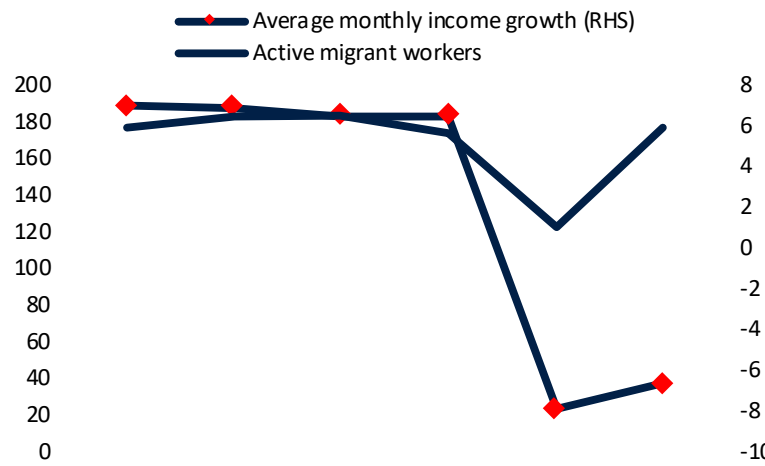

B. Enrollment of migrant workers in urban workers' socialinsurance schemes in 2017 (Share in percent)

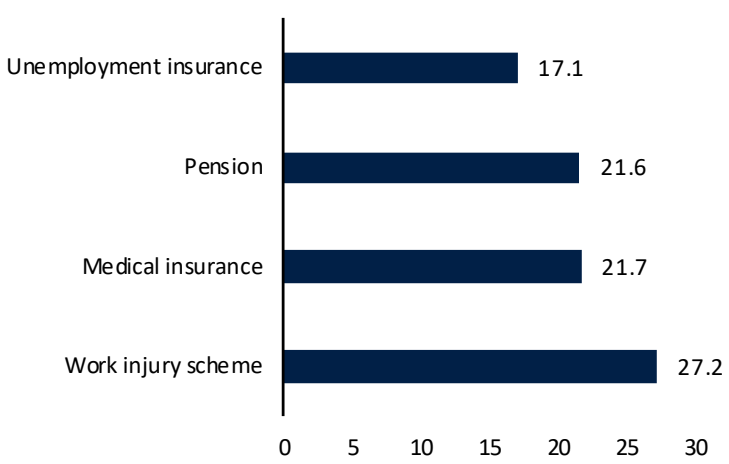

Source: NBS; Ministry of Human Resources and Social Security (MOHRSS); World Bank Staff estimates.

\section{Corporate revenue and profits have taken a hit}

Corporate balance sheets have been strained. As sales collapsed and supply chains were temporarily disrupted, many businesses experienced serious cash flow problems and found it difficult to pay rent and salaries and service their loans. Industrial profits fell sharply, by 34.9 percent y/y in 2020Q1. While the impact was broad-based, auto (-80.2 percent), electrical machinery (-47.0 percent), and chemicals ( -56.5 percent) were hit the hardest. Industrial profits have bottomed out in 2020Q2, posting a positive 5.1 percent y/y average growth. This reflected both stronger topline revenue growth as well as recovering profit margins. In particular, profit growth in computer manufacturing rose sharply to an average of 48.7 percent $\mathrm{y} / \mathrm{y}$ in 2020Q2, probably benefiting from a mass shift to home-based work and rising demand for electronic equipment.

Private firms fared better than SOEs during the pandemic. Overall, SOEs saw revenues decline by 5.9 percent $y / y$ in the industrial sector in the first half of 2020, while private firms registered a 4.4 percent $y / y$ drop. Profits of industrial SOEs, which dominate the raw materials sector, contracted by 28.5 percent y/y in the half of 2020. Profits of private industrial enterprises contracted by 8.4 percent during this period. Private firms were also more profitable than SOEs. Their average return on assets (ROA) fell to 5.1 in 2020H1 from 6.6 percent in 2019, but was still a lot higher than the 2.9 percent for SOEs

Small and Medium Sized Enterprises (SMEs), which tend to have more limited working capital buffers, had to absorb abrupt and sharp revenue losses. Over a third of small and medium enterprises (SMEs) surveyed by Tsinghua and Peking Universities in February 2020 considered access to working capital as a major challenge. According to this survey, the availability of cash flows in such enterprises would generally last under three months. In contrast, larger firms report fewer cash flow problems, with 76 percent of the firms having enough cash flow to sustain them for more than three months. Almost one quarter of the surveyed SMEs planned to cut staff and pay, and 16 percent chose to suspend production and go out of business. 


\section{Figure 17. Industrial profits}

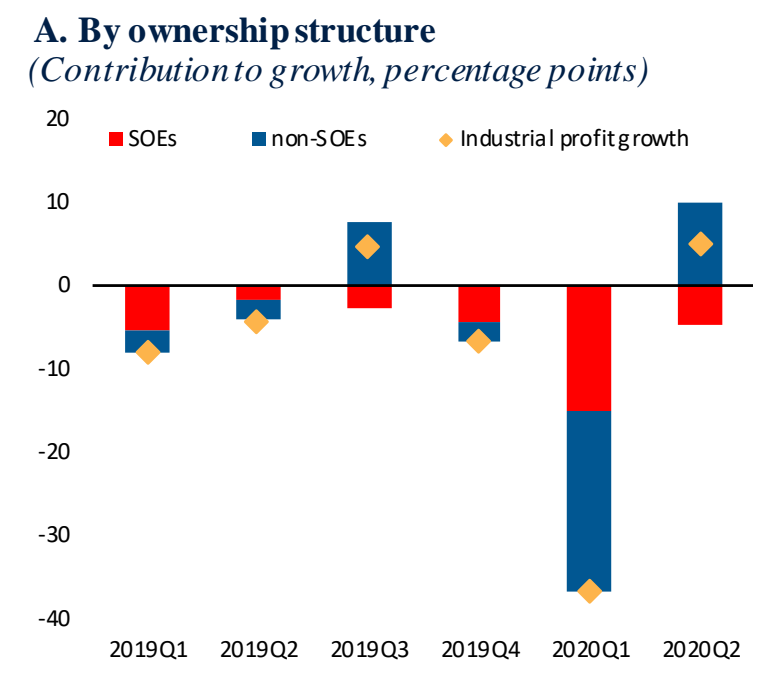
B. By industrial sectors
(Contribution to growth, percentage points)
Auto $\quad$ Equipment \& electronics
- Chemical\& metal a Mining \& utility
$20 \quad$ Other $\quad$ Industrial profitg rowth

(Contribution to growth, percentage points)

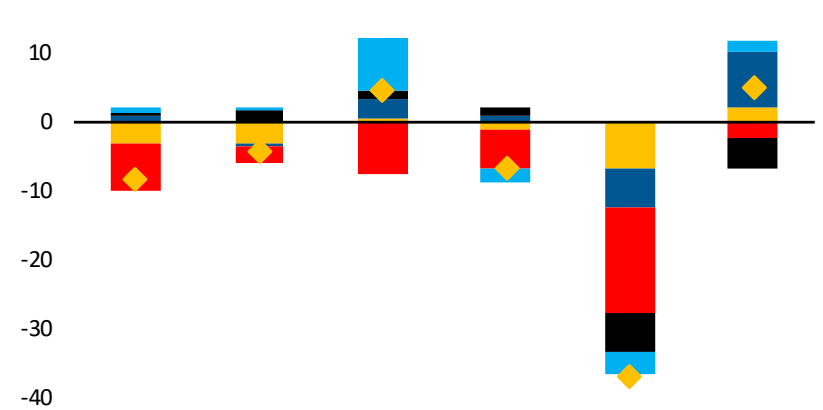

Source: NBS.

2019Q1 2019Q2 2019Q3 2019Q4 2020Q1 2020Q2

With corporates already highly leveraged, risks of serious corporate distress have become more acute. ${ }^{11}$ Both corporate bond defaults and bankruptcy cases increased in $2020 \mathrm{H} 1$. According to the Supreme People's Court, 4,693 bankruptcy cases were filed in 2020Q1, an increase from 2,324 cases during the same period last year. According to the Supreme People's Court, 9,682 bankruptcy cases were filed in 2020H1, an increase from 5,283 cases during the same period last year. Bond defaults are also on the rise. According to WIND Information Co., Ltd, China's corporate bond default rate was 1 percent from 2020H1, up from 0.6 percent in 2018 and 0.9 percent in 2019 (Figure 18.A). While there are some cases of acute corporate distress, mass bankruptcy was avoided through significant liquidity support and forbearance.

\section{Figure 18. Financial sector}

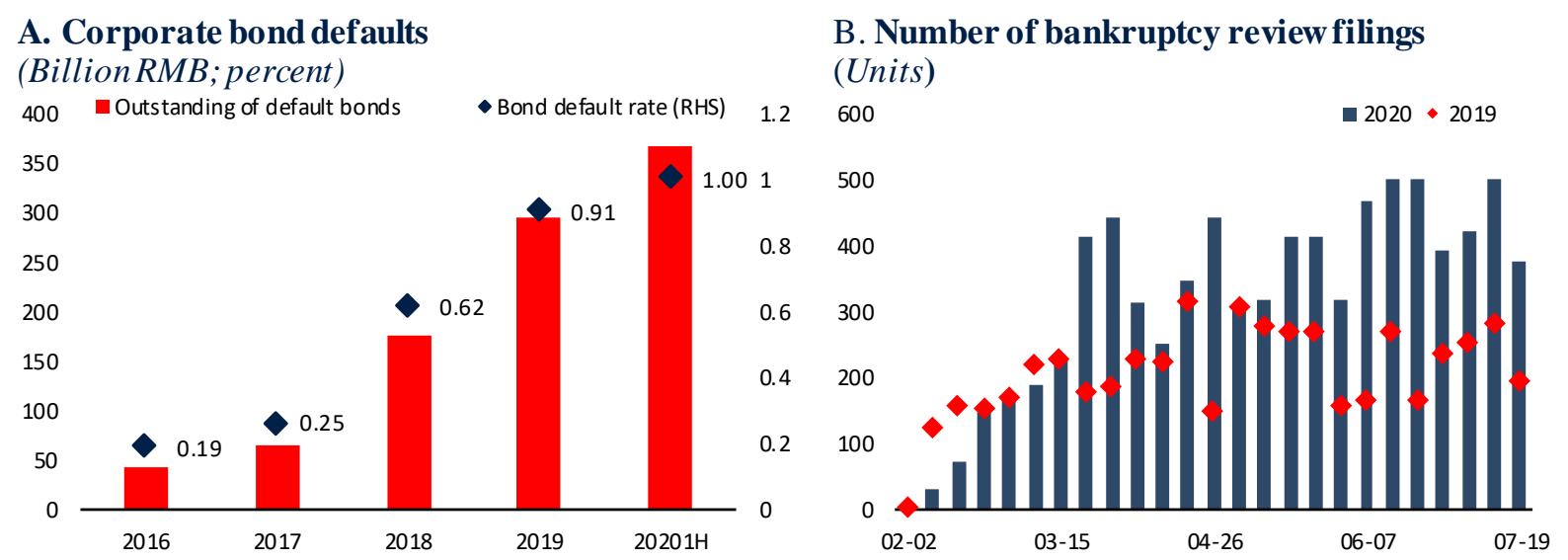

Source: WIND database; National Enterprise Bankruptcy Information Disclosure Pla tform https://pccz.court.gov.cn/pcajxxw/index/xxwsy; World Bank.

Note: Bond default rate is defined as outstanding of defaulted corporate bonds as share of total corporate bond outstanding.

\footnotetext{
${ }^{11}$ Corporate debt currently stands at around 165 percent of GDP and is expected to increase further as the special lending facilities introduced for COVID relief are utilized.
} 


\title{
Credit risks are rising, foreshadowing potential banking sector troubles
}

The confluence of a collapse of corporate profits, rising unemployment, and lost income has elevated credit risks in Chinese banks, and asset quality has started to deteriorate. The total volume of NPLs has risen only slightly from RMB 2.4 trillion (2.4 percent of GDP) to RMB 2.6 trillion (2.6 percent of GDP) between December 2019 and March 2020, while the non-performing loan (NPL) ratio inched upward, from 1.86 to 1.91 percent over the same period. However, according to estimates by the China Banking and Insurance Regulatory Commission (CBIRC), COVID-19-related dedicated credit and loan extensions amounted to RMB 4.4 trillion (4.4 percent of GDP) until mid-May. Preliminary analysis of available data on a sample of A-listed non-financial companies also indicated that total "debt-at-risk" (defined as those where earnings of the borrower cannot fully cover interest expenses) shot up from 6 percent in December 2019 to 23 percent at the end of March 2020 (Figure 19.B). While these risks may recede with the resumption of business activity, non-performing loans are likely to increase once forbearance on recognition of NPLs ends as planned in early 2021, and loan losses are realized. Several regional banks are particularly vulnerable, due to their high exposure to the commercial service sector, unsecured consumers and micro and small enterprises (MSEs), as well as their weaker financial performance even before the crisis (Figure 19.C and 19.D). Although banks on the aggregate have robust capital cushions, this is not evenly distributed.

\section{Figure 19. Credit risks and credit allocation}

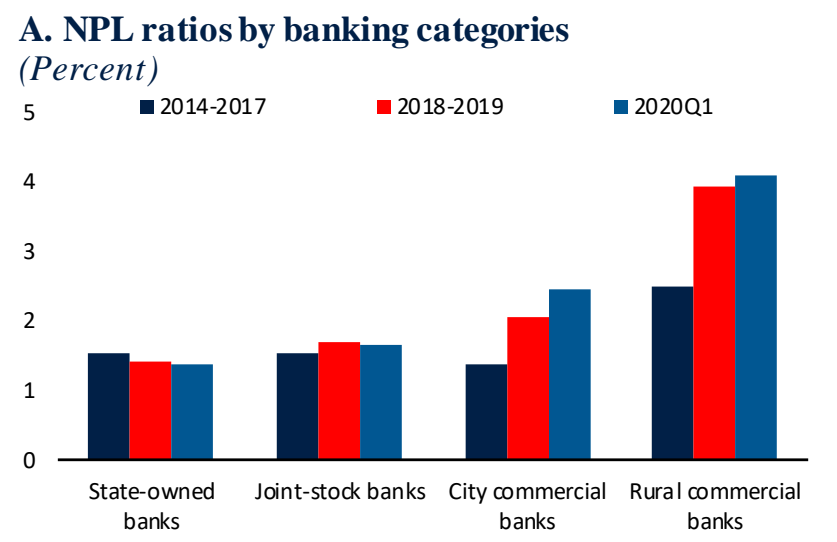

\author{
B. Debt-at-risk ratio of listed non-financialfirms \\ (Percent)
}
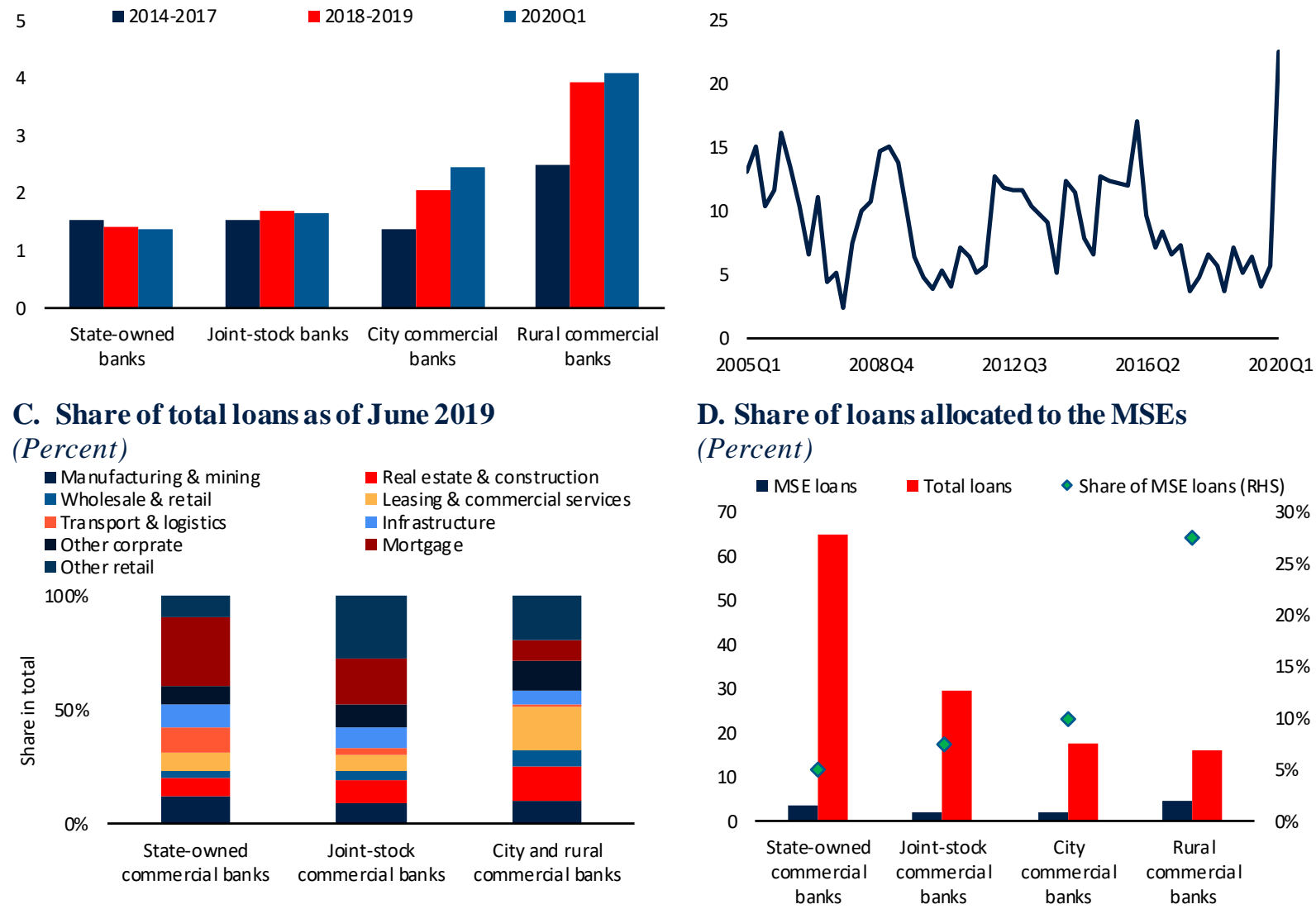

Source: Moody's; CBIRC; WIND database; World Bank.

Notes: B. The debt at risk ratio is defined as the percentage of borrowing by companies unable to generate sufficient earnings before interest and taxes (EBIT) to cover debt interest payment. 


\section{The fiscal deficit is widening}

Fiscal revenues have fallen because of the economic downturn and the adoption of tax relief as part of China's policy response. Revenues in the consolidated public finance and government fund budgets declined by 8.6 percent $y / y$ in the first half of 2020, reflecting weaker corporate profits, subdued consumption, income losses, and rising unemployment. Growth in tax revenues was particularly weak, dropping by 11.3 percent y/y in $2020 \mathrm{H} 1$, while non-tax revenues contracted by 8 percent $\mathrm{y} / \mathrm{y}$. Notably, value-added tax (VAT) and corporate income tax revenues, which together accounted for over half of overall tax revenues, contracted by 19.1 and 7.2 percent y/y in the first half of 2020, respectively, reflecting weak corporate profits as well as targeted VAT cuts and exemptions implemented this year. Meanwhile, individual income tax revenues grew by only 2.5 percent $y / y$ in $2020 \mathrm{H} 1$, reflecting income losses and rising unemployment pressures amid the outbreak. Growth in property-related taxes also moderated, owing to a weaker real estate market.

Meanwhile, expenditures have risen moderately. Overall expenditures rose by 0.6 percent $y / y$ in the first half of 2020, compared to 15.0 percent y/y during this period last year. Spending on social security and employment rose by 1.7 percent y/y in $20201 \mathrm{H}$ due to rising social transfers and wage subsidies and spending to stabilize employment. Health spending dropped by 0.2 percent $y / y$ in $20201 \mathrm{H}$, despite increased fiscal support for epidemic prevention and control. Expenditures for non-essential services contracted in 2020H1.

The consolidated budget registered a higher deficit of 3.3 percent of GDP in the first half of 2020, compared to 2.1 percent of GDP during the same time last year. The higher deficit was, to a large extent, financed by increased government bond issuance. Net financing from central government bonds increased to RMB 1096 billion (1 percent of GDP) in the first half of 2020, from RMB 516 billion ( 0.5 percent of GDP) in 2019H. During the same period, net financing from local government bonds increased to RMB 2,851 billion (2.9 percent of GDP) from RMB 2,221 billion (2.2 percent of GDP), due primarily to a higher pre-approved local government special bond quota at the start of the year and surging infrastructure and public health spending, funded through additional local government bond issuance in recent months. The size of the overall policy stimulus is discussed further below.

\section{The pace of debt buildup has accelerated}

With easier financing conditions, credit growth to the non-financial sector accelerated to an average of $\mathbf{1 1 . 9}$ percent $y / y$ in the first half of 2020 , compared to 11.2 percent during the same period last year. ${ }^{12}$ Bank loans grew by 12.7 percent y/y in $1 \mathrm{H}$, mainly reflecting COVID-19-related credit and loan extensions to SMEs. Growth in net corporate bond financing accelerated sharply to 17.7 percent y/y in the first half of 2020 from 11.4 percent y/y during this period last year. Government bond issuances also picked up as the government frontloaded some of the infrastructure investment financings. Non-bank lending continued to contract, reflecting a continued clampdown on shadow banking. Still, the pace of contraction slowed to -7.3 percent $y / y$ on average in $2020 \mathrm{H} 1$ from -10.1 percent during the same period last year.

China's aggregate debt-to-GDP ratio reached 283 percent of GDP in $2020 \mathrm{H1}$, also reflecting lower nominal GDP growth (Figure 20.A). The spike in the debt ratio by 15 percentage points in Q1 was the highest for China on record and came on the back of already elevated debt levels. Driven by accelerated credit growth, China's aggregate debt-to-GDP ratio rose by another 8 percentage points in 2020Q2.China's

\footnotetext{
${ }^{12}$ Total credit $=$ total social financing - equity financing + government bonds - local government special bonds, using the revised definition of TSF, which includes special government bonds, as set-backed securities held by banks, and loan write-offs .
} 
total debt increased by 70 percentage points during 2008-13, the third-largest increase in the debt ratio in EMDE history (Figure 20.B; Kose et al. 2019). A heavy debt burden accumulated as a result of past reliance on investment-fueled growth weighs on future growth and investment prospects and presents risk to financial stability. It is estimated that with the debt interest burden already exceeding 10 percent of GDP in 2020 , more than one-third of new credit will be used merely to service the existing debt.

Debt has expanded across sectors. Household leverage continued to rise and reached 59 percent of GDP in 2020Q2, up from 55 percent of GDP in 2019Q4 (Figure 20.C). Explicit government debt rose on higher government bond issuances. At the same time, implicit liabilities of local governments and state-owned enterprises (SOEs) also rose, as evidenced by a pickup in Local Government Financing Vehicle (LGFV) bonds this year. Corporate debt is on the rise, too. The liabilities to asset ratio of both state-owned and private industrial firms has increased since the start of the year, though the debt ratios of SOEs are still significantly higher (Figure 20.E). China's total external debt is low, however. Including the debt of Chinese subsidiaries operating abroad, it was estimated at less than 20 percent of GDP by the end of 2020Q2. ${ }^{13}$

\section{Figure 20. Credit growth}

\section{A. GDP growth and total credit stock to GDP (Percent of GDP; percent)}

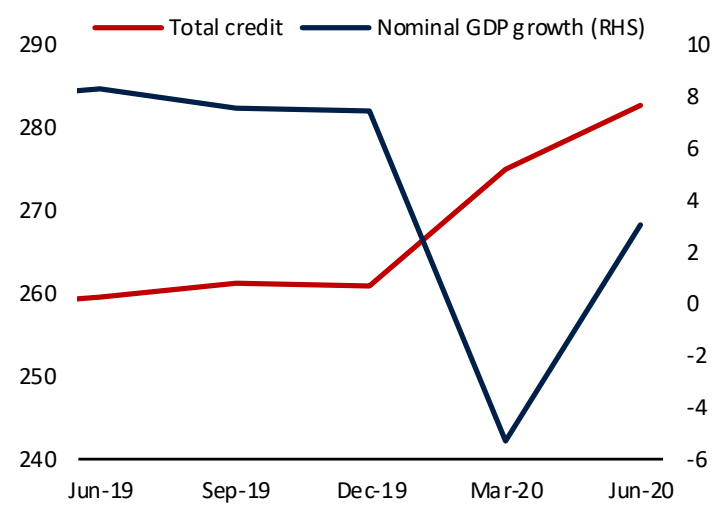

C. Household debt

(y/y percent; percent of GDP)

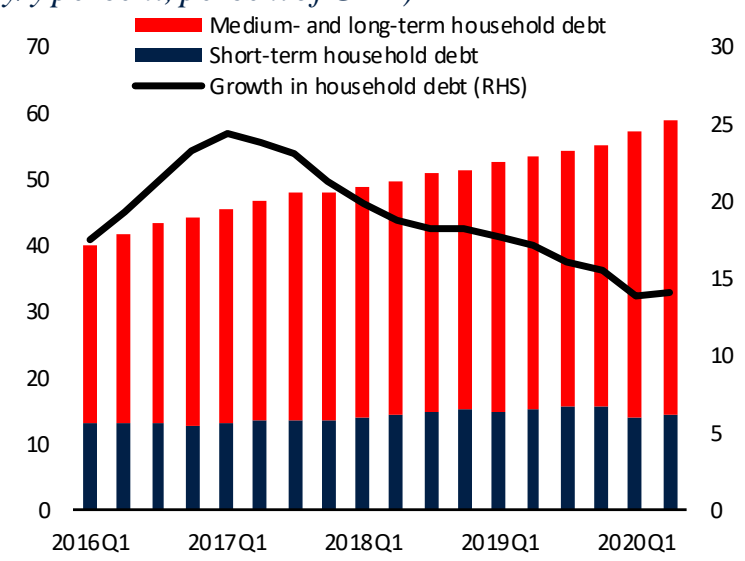

\section{B. Peak five-year changein total debt in EMDE} (Percent of GDP)

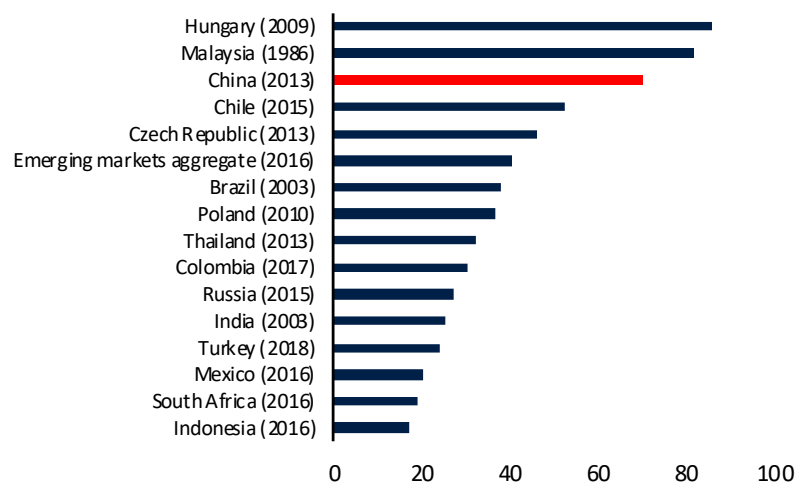

D. Non-bank lending

(Share in percent; $y / y$ percent)

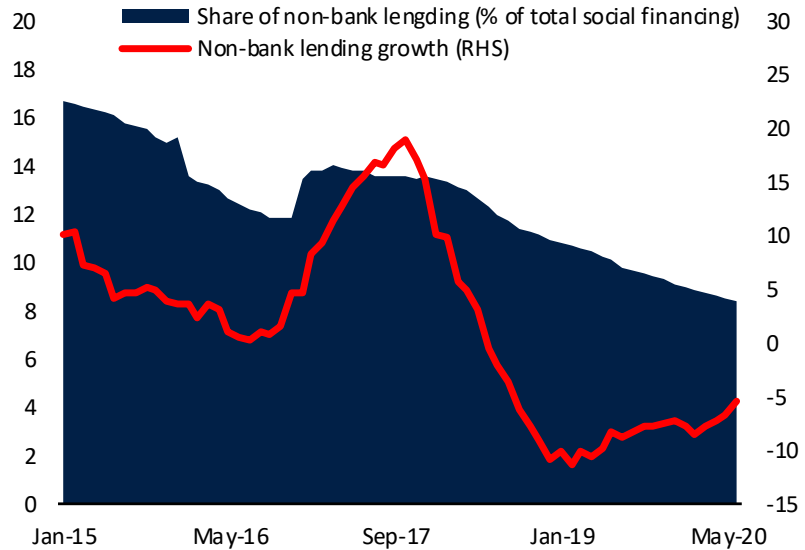

\footnotetext{
13 The official external debt data provided by the State Administration of Foreign Exchange (SAFE) is based on residency, and therefore would not include the debt of Chinese subsidiaries operating abroad.
} 


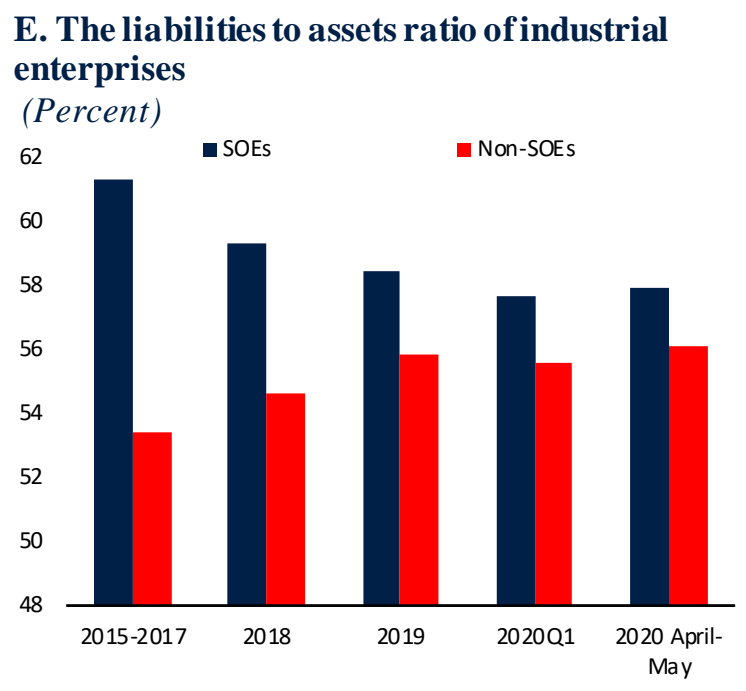

\section{F. Net financing of government and LGFV bonds \\ (Percent of GDP)}

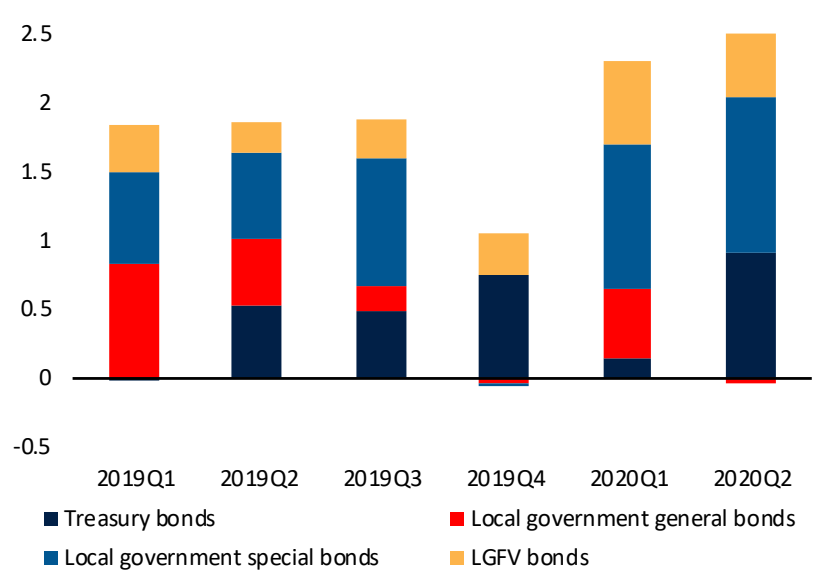

Source: Bank for International Settlements; Haver Analytics; PBOC; WIND database; World Bank.

Notes: A. Total debt is defined as the sum of domestic and external debt, and includes household, nonfinancial corporate, and public sector debt expressed as a share of four-month average quarterly seasonally adjusted GDP. La st observation is 2020Q2. B. The year in the bracket is the end of the five-year period.

\section{Policies have aimed to cushion the economic and social impacts of the pandemic-induced downturn}

Since the onset of the outbreak, the Chinese authorities have continuously stepped up economic policy measures to cushion the economic and social impacts of the pandemicinduced downturn. The initial policy response aimed to bolster market confidence, relieve nearterm cash flow problems, and mitigate more permanent economic damage in the form of bankruptcy, unemployment, and rising NPLs. As the lockdown measures were rolled back, the policy focus shifted toward supporting the recovery and pledging accommodative monetary policy and additional public investment, tax relief, and social transfers. In a notable departure from a practice first established in 1994, the government did not set an explicit annual GDP growth target for this year, citing unprecedented uncertainties and challenges caused by the COVID-19 outbreak. Instead, government policies have emphasized job creation as the main economic policy objective, aiming to create nine million additional jobs and keeping the urban unemployment rate target at six percent.

China's central bank has ensured ample liquidity to bolster market confidence and relieve banks' near-term liquidity constraints. The PBOC only modestly lowered short- and long-term policy rates (Figure 21). Since February, both repo and medium-term facility rates have declined by 30bps. The central bank also lowered the 1-year and 5-year loan prime rate by 30 and 15 bps to 3.85 and 4.65 percent, respectively, leading to a drop in interbank market rates and bond yields by $20-50$ bps since February. While
Figure 21. Policy rate cuts and market rates (Percent)

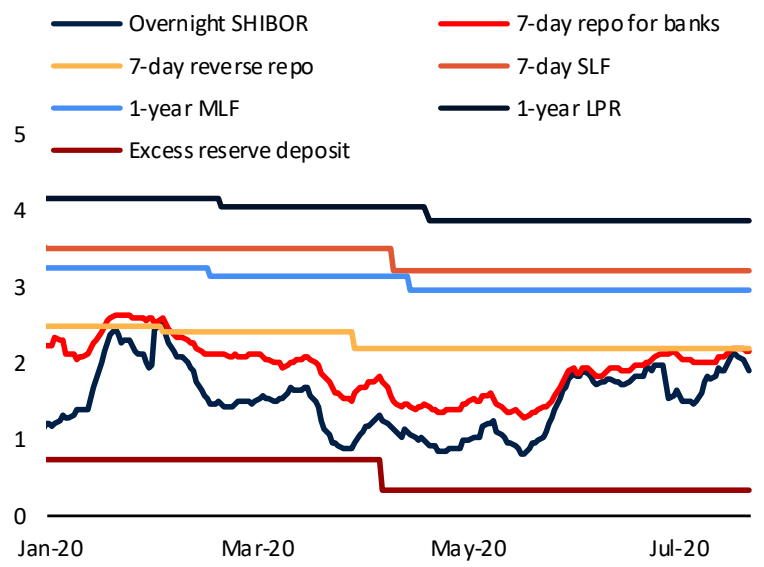

Source: PBOC; World Bank. 
the cut in policy interest rates was relatively modest, cuts in reserve requirements have released significant liquidity. The PBOC has cut the required reserve ratio three times, unlocking about RMB 1.75 trillion in liquidity (1.75 percent of GDP), some targeted to specific banks, including those lending to SMEs. However, unlike other major central banks, PBOC has refrained from quantitative easing and asset purchases, as reflected in the relatively limited expansion of the PBOC balance sheet (Figure 22.B).

In addition, special refinancing facilities by the PBOC and policy banks have provided banks with the funds to extend subsidized lending to targeted sectors and firms. PBOC has extended about RMB 2.2 trillion (2.2 percent of GDP) in re-lending and re-discount facilities for banks to increase credit to affected businesses and SMEs. In addition, policy banks were offered an increase of RMB 1,350 billion (1.35 percent of GDP) credit and bond quota to offer lending to private enterprises, including SMEs with preferential interest rates. Preferential loans were extended to firms involved in the production, transport, and sales of epidemic-related medical supplies and daily necessities.

\section{Figure 22. Liquidity provision by PBOC}

\section{A. PBOC ensured ample liquidity provision (Percent of GDP)}

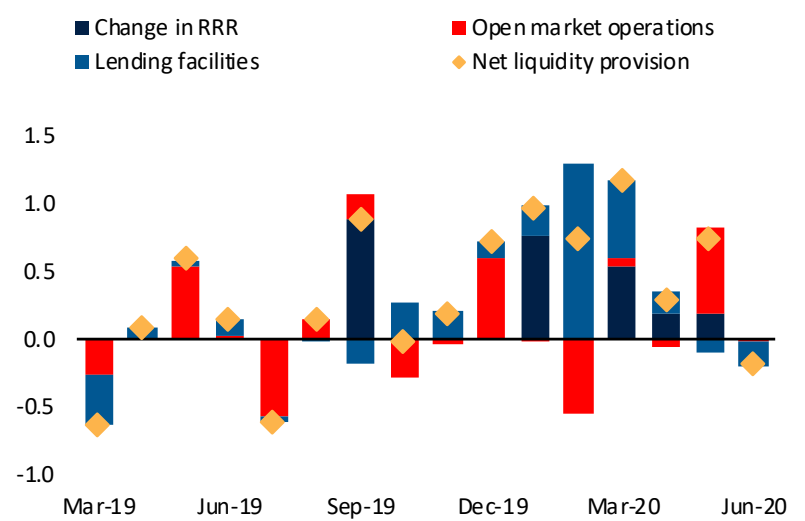

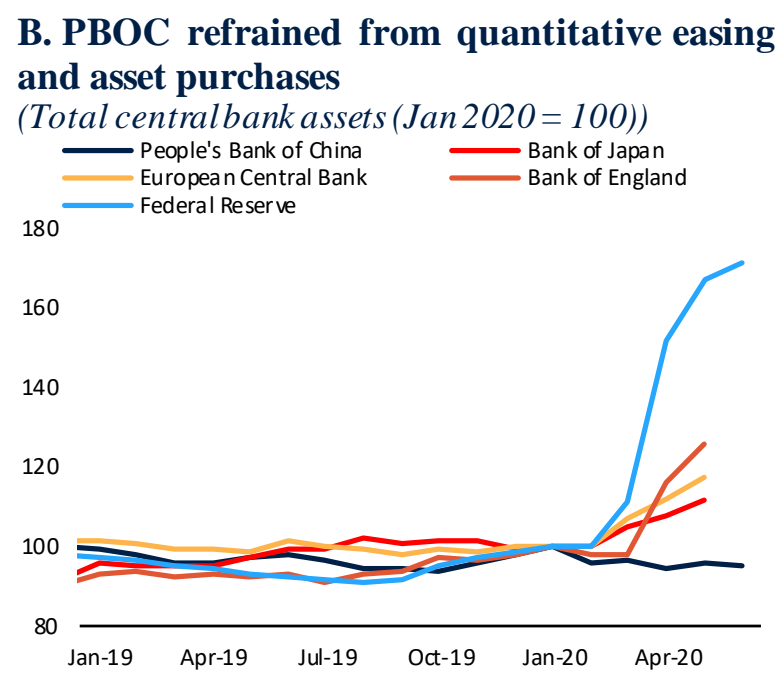

Source: PBOC; Bank of Japan; Federal Reserve; Bank of England; CEIC; World Bank.

Meanwhile, financial regulators adopted regulatory forbearance to allow banks to cope with increased payment difficulties of their borrows and rising non-performing loans (NPLs). Penalty interests on overdue payments were exempted, and overdue debt caused by the outbreak was not counted as a default (to avoid any negative impact on a firm's credit record). The PBOC and CBIRC jointly stated that micro and small enterprise loans that are scheduled to mature this year were allowed to be extended through March 31, 2021, as long as borrowers keep employment stable. Similarly, individuals were allowed to defer the repayments of personal loans (e.g., mortgages and credit card bills) and renegotiate interest rates. In the corporate bond market, the China Securities Regulatory Commission relaxed restrictions on issuing new bonds that repay maturing debts.

On the fiscal front, China adopted a more expansionary stance with a combination of revenue and spending measures. Announced fiscal measures are expected to widen the augmented fiscal balance ${ }^{14}$ to an estimated 11.8 percent of GDP in 2020 from 6.4 percent last year, amounting to a fiscal impulse to the tune of about 5.4 percent of GDP (Figure 23.A). While in line with stimulus measures in other middle-

\footnotetext{
14 The augmented fiscal balance adds up the public finance budget, the government fund budget, the state capital management fund budget, and the social security fund budget.
} 
income countries, the size of China's fiscal support measures has been more moderate than in other major economies (United States, European Union, and Japan) (Figure 23.B). In terms of composition, China has relied on a combination of revenue and spending measures, including tax cuts and deferrals, additional social transfers, and more traditional infrastructure investment. Specific measures include the following:

- The headline budget deficit will be at least 3.6 percent of GDP for this year, compared to 2.8 percent of GDP in 2019. This reflects a combination of lower revenue performance due to the economic downturn and tax measures. Notably, the authorities extended most existing fiscal relief measures, e.g., VAT exemptions, reductions and deferrals for smaller taxpayers, and some fee reductions to the end of this year, as well as the carry-over of the VAT tax rate cut announced in 2019.

- Local government bond issues to finance inf rastructure are expected to reach 3.7 percent of GDP compared to 2.1 percent of GDP last year. Key areas of policy support include infrastructure investment, in particular 5G infrastructure and information network construction, and investment related to new urbanization, such as investment to promote city cluster connectivity.

- In addition, special national treasury bonds equal to 1 percent of GDP have been announced. The proceeds of the special treasury bond will be transferred to local governments to facilitate additional spending needed to protect people's livelihoods, reduce taxes and administrative fees, lower the burden of rents and interest payments of the corporate sector. The proceeds also will support consumption and investment, depending on local governments' needs.

- The combined amount of carry-over funds and fiscal reserves are expected to reach 3 percent of GDP, compared to 2.1 percent of GDP in 2019. The budget report said the combination of the central budget stabilization fund, central government funds, and SOE profit transfer would reach 0.9 percent of GDP, triple the 0.3 percent of GDP last year. Local government carryover would also pick up to 2.1 from 1.9 percent of GDP. Carryover funds will be used to finance additional spending needs at the national and subnational level.

- The social security fund will turn to a deficit of 0.5 percent of GDP from a surplus of 0.6 percent of GDP in 2019. This is mainly due to the temporary exemption of corporates' social security contribution, which has been extended to the end of this year. As a result, social security revenues will decline by 4.4 percent in 2020, as opposed to a growth of 2.3 percent in 2019.

Figure 23. Fiscal stimulus measures

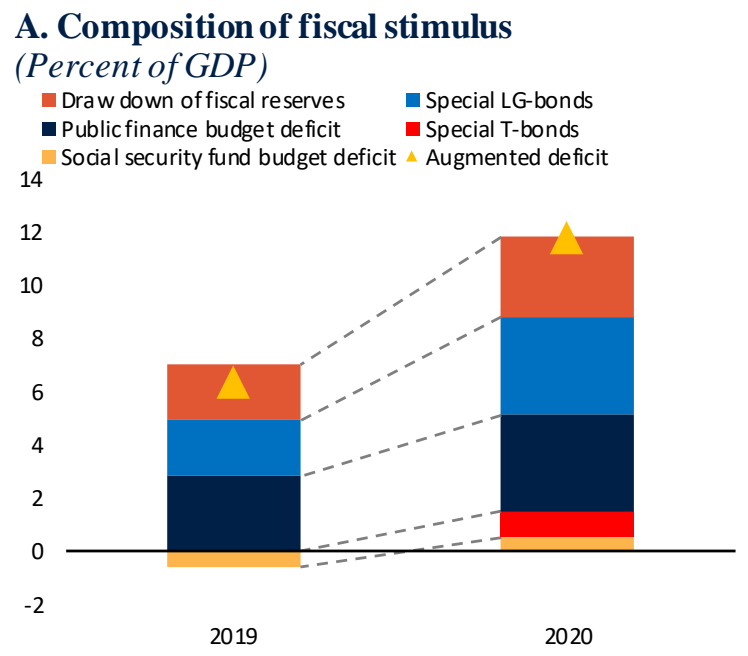

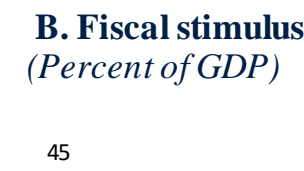

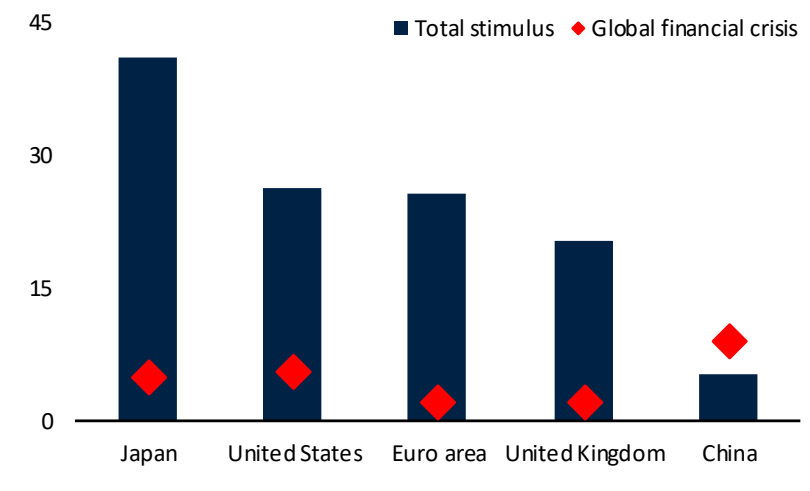

Source: International Monetary Fund; MOF; World Bank.

Note: Underlying definitions of the scope of support measures may vary and include on-budget and off-budget support. 
China has also adopted policy measures to protect jobs, provide income support, and facilitate the resumption of production and work. Those measures largely rely on pre-existing social protection programs but temporarily expand their coverage and the size of benefits. This includes deploying the emergency assistance program to provide income and social support for stranded people during the lockdown, topping up Dibao benefits for the existing beneficiaries, offering unemployment insurance benefits for those with less than a year of contributions into the unemployment insurance fund, and extending social protection programs to cover migrant workers. Total public spending for China's social protection and jobs policy response is estimated to be 1.65 percent of GDP, considerably above the 0.51 percent of GDP average in other upper middle-income countries. ${ }^{15}$ It is noteworthy that the majority of public spending for China's social protection and jobs policy response comes from social insurance, and is aimed at maintaining employment stability (see chapter IV).

Finally, the authorities have announced several structural reform measures to engender a stronger recovery. This includes steps to further relax the household registration system — a key impediment to labor mobility and equal access to social services - encouraging cities with populations under three million to eliminate hukou requirements, and megacities with more than five million people to remove hukou requirements in suburban areas, albeit only for selected groups of migrants, based on age and education level. In addition, the authorities have also emphasized the importance of embracing economic opening up, announcing a further shortening of the "negative list" for foreign investment, more pilot programs for service sector liberalization, and equal treatment of domestic and foreign enterprises.

\section{Outlook, Risks and Policy Considerations}

\section{Short-term outlook}

In China, the baseline forecast envisions a sharp slowdown of growth to 1.6 percent this year- -0.6 percentage points higher than projected in June — but still the slowest expansion since 1976. ${ }^{16}$ The baseline assumes that efforts to suppress the virus will broadly succeed, and that localized COVID-19 flareups are effectively contained and won't cause major disruptions in economic activity. Under this scenario, a sharp contraction in 2020Q1, and a subsequent rebound in 2020Q2, would be followed by a gradual but sustained recovery as domestic demand trends toward normal levels and partly offsets weak external demand. The recovery will continue in the second half of this year, but momentum will slow. The baseline projections assume that continued fiscal policy support is effective in stimulating private consumption, and public investment and structural reform measures bolster business confidence and crowd in private investment. The forecast also assumes that financial conditions will remain broadly at current levels. Under this scenario, GDP growth would stabilize slightly below its earlier trend level by late-2021, as investment shortfalls and persistent drops in employment reduce the economy's supply capacity, preventing it from returning to the pre-pandemic trajectory (see Box 7 on potential growth trajectory).

While supply side disruptions have largely eased, weak domestic and external demand and heightened uncertainty will continue to restrain the pace of recovery, despite measures taken to contain the economic fallout. The recovery in headline growth in 2020Q2 comes with a mixed picture regarding the underlying drivers - a limited rebound in consumer-oriented services sector demand, subdued private investment and continuously weak labor market conditions. The baseline projections assume further

\footnotetext{
${ }^{15}$ See (Gentilini, U., M. Almenfi, P. Dale, A.V. Lopez, I.V. Mujica, R. Quintana, and U. Zafar. 2020).

16 The revised forecasts reflect stronger-than-expected 2020Q2 GDP growth and high frequency activity data than as sumed in June 2020 baseline forecast.
} 
normalization, as supply side constraints continue to ease and pent-up demand is gradually released in response to easing social distancing measures and demand-stimulating and confidence-boosting policy support. Nevertheless, fragile business and consumer confidence are expected to weigh on China's economic recovery. The external environment will remain challenging until global output, trade, and investment growth normalize and global policy uncertainty is reduced. The baseline scenario for China is consistent with the global baseline scenario, which assumes that the outbreaks in advanced economies continue to slow, allowing most countries to gradually lift lockdown measures around the middle of the year, even if some control measures remain in place during the third quarter to prevent flare-ups. Outbreaks in EMDEs and the stringency of related lockdown measures are expected to reach their peaks somewhat later than in the advanced economies. In the baseline scenario, output in advanced economies shrinks by 7 percent, and global trade flows fall by 13.4 percent (World Bank 2020d).

Private consumption is expected to recover but remain muted because of the pandemic's lingering effect on incomes, consumer behavior, and confidence. Income and wage losses have disproportionately affected low- and median-income households and vulnerable groups with a higher propensity to consume, resulting in a significant negative impact on consumer spending and sentiment. In addition, the extended period of soft social distancing measures is expected to lead to behavioral changes and constrain the recovery of services involving face-to-face interactions, such as tourism, entertainment, and to some extent, traditional retail. This could weigh on potential output to the extent that frictions in labor markets prevent reallocation of labor to other expanding sectors. The recent shift in China's fiscal policy toward stimulating consumption is expected to partly offset the impact of the outbreak. Specifically, fiscal measures to stabilize employment and lower social security contributions are expected to support disposable incomes and stimulate household consumption.

Weak private investment will continue to be largely offset by increased public investment. Corporate capital expenditure is likely to remain weak, reflecting strained corporate revenue, fragile business confidence, and heightened policy uncertainty. Weak private investment, especially in the manufacturing sector, is expected to continue to be largely offset by a pickup in infrastructure investment. Infrastructure investment will also be boosted by recent policy changes that allow part of special local government bond (LGB) proceeds to be used as equity capital for qualified projects, lower equity capital requirements for some infrastructure projects, and the prohibition to use special LGB for real estate and commercial projects.

Externally, the pace of recovery in global demand is expected to be hindered by the global recession, remaining travel bans, stringent border controls, and impaired international transportation. Disruptions and trade dislocation will likely linger, and exports are expected to remain under pressure even if demand for some exports (medical supplies) and necessities may remain robust for some time. The weakness will be partly offset by China's rebound from the pandemic fallout ahead of the other major economies. In 2021, import and export growth are expected to gradually pick up, barring new unexpected shocks, as global demand stabilizes and domestic social distancing measures, along with restrictions on international travel and border controls, are gradually lifted in major economies.

\section{Box 5. Global outlook ${ }^{17}$}

The pandemic has caused significant disruptions to the global economic outlook and triggered sharp and broad-based revisions to global growth. Global output is projected to contract sharply in 2020 - marking the deepest global recession in eight decades, despite unprecedented policy support (Figure 24. A; World Bank 2020d). This reflects a widespread sudden stop of global activity in 2020H1,

\footnotetext{
${ }^{17}$ Draws heavily on the World Bank June 2020 Global Economic Prospects report (World Bank 2020d).
} 
reflecting the national lockdowns implemented worldwide to contain the spread of the outbreak. The pandemic is expected to plunge the majority of countries into recession in 2020, with per capita output contracting in the largest fraction of countries since 1870. GDP in the advanced economies, where almost all major countries have implemented strict social distancing measures amid the severe spread of the virus, is projected to shrink by 7 percent this year. EMDEs are envisioned to contract by 2.5 percent.

\section{Figure 24. Global GDP growth and trade outlook}
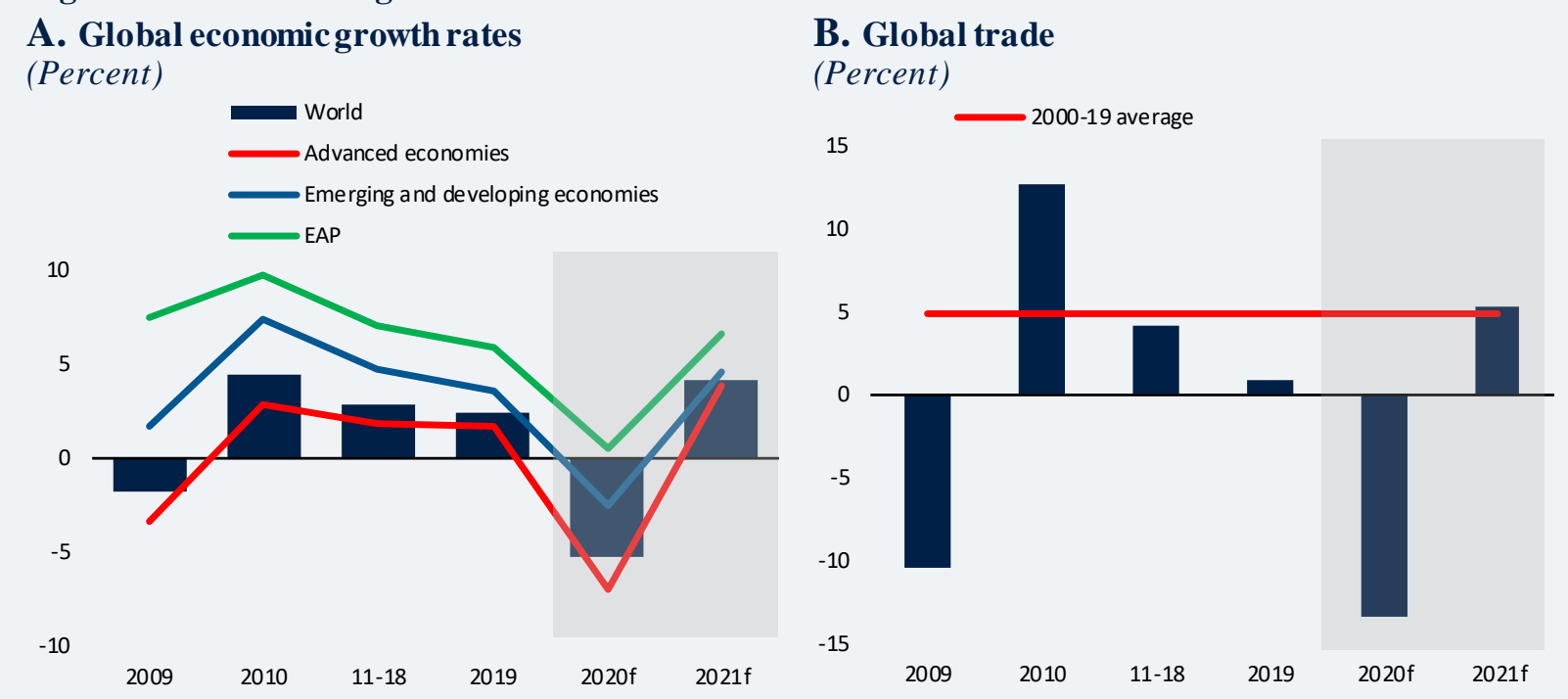

Source: Ha ver Analytics; World Bank.

Note: A. B. Aggregate growth rates are calculated using constant 2010 U.S. dollar GDP weights. Is based on GDP projections published in the June 2020 World Bank Global Economic Prospects report. Da ta in shaded areas are forecasts. A. EAP=developing East Asia and Pacific region. B. Trade is measured as the a verage of export and import volumes.

The sharp fall in activity in $2020 \mathrm{H} 1$ is expected to contribute to a contraction in global trade of about $\mathbf{1 3 . 4}$ percent in $\mathbf{2 0 2 0}$ - larger than experienced during the global financial crisis (Figure 24.B). Some recovery is expected in 2021 , as domestic social distancing measures, along with restrictions on international travel and border controls, are gradually lifted in major economies, and global demand picks up. The depth of contraction in global trade and the strength of its recovery depend on the outbreak's duration and the pace and effectiveness of exit strategies.

Oil demand is expected to fall by 8.6 percent in 2020. Such a decline would be unprecedented, surpassing the previous record fall of 4 percent in 1980. Global oil production is also starting to fall, although at a slower pace than demand (Box 1; World Bank 2020b). Overall, oil prices are expected to average \$32 per barrel in 2020 and \$38 per barrel in 2021. Metals prices are anticipated to decline 16 percent in 2020 before showing a modest increase in 2021. This forecast is predicated on a recovery of Chinese demand, which accounts for around 50 percent of the consumption of base metals. Agricultural prices, which weakened over the first half of the year, are expected to decline only marginally in 2020 as a whole, as they are less sensitive to economic activity than industrial commodities, particularly at higher-income levels.

Thus far, an extraordinary policy response has prevented the slowdown in activity from becoming a financial crisis. Nonetheless, financial conditions will remain fragile for many market participants. A prolonged disruption to economic activity could exacerbate financial stress, which could lead to widespread financial crises. Lower-for-longer commodity prices could trigger economic and financial distress among commodity producers. 
Global growth is projected to recover in 2021 as containment measures gradually ease and economic activity normalizes, helped by massive policy support. The timing and strength of a global rebound depend on the duration of the pandemic, the timing of exit strategies, and the effectiveness of policy actions in preventing financial meltdowns, restoring global consumer and investor confidence, boosting economic activity, and resuming global trade and travel. Despite the projected rebound of global growth, the level of global output in 2021 in 2021 is projected 5.9 percent below that of January 2020 GEP forecasts (World Bank 2020b).

There is high uncertainty around the global growth forecast. The global recession would be deeper than the baseline forecast, if bringing the pandemic under control took longer than expected, or if financial stress triggered cascading defaults. In a scenario where an additional three months of stringent lockdown measures are required, global output would shrink by almost 8 percent in 2020. Conversely, the predictable removal of pandemic-control measures, coupled with the rapid and unprecedented global policy response can trigger a rapid recovery in confidence and employment, unleashing pent-up demand. However, even with these positive developments, the contraction in global output of 3.7 percent in 2020 would still be about twice as deep as during the global recession of 2009, and EMDE growth would still be negative.

The pandemic and the associated global recession are likely to have durable impact through multiple channels, including lower investment and innovation, erosion of the human capital, and retreat from global trade and supply chains. These effects may well lower potential growth and labor productivity in the longer term. The long-term damage will be particularly severe in economies that suffer financial crises, and, in energy exporters, due to plunging oil prices. The exceptional severity of the pandemic and economic collapse raises concerns about the risk of "super-hysteresis": not only a permanent loss of output levels but a permanent slowdown in potential output growth (Ball 2014). For example, in the average EMDE, over a five-year horizon, a recession combined with a financial crisis could lower potential output by almost 8 percent (World Bank 2020b).

The baseline projections assume that the authorities will continue calibrating policies to prevent a widening of output gaps (Box 6). Additional fiscal easing is expected to partly offset the downward pressures associated with the lingering impact of trade tensions, softer property activities, and subdued fixed asset investment in the manufacturing sector. Monetary easing will proceed cautiously to avoid releveraging, currency depreciation, and abrupt capital outflows. Overall, while additional fiscal support and monetary easing are expected to help lift domestic demand, they won't be able to fully mitigate the impact and lingering effects of the outbreak.

Inflation is likely to remain soft. The headline CPI inflation is expected to moderate, as both food and energy price inflation have come down. The core CPI is expected to edge up on the back of gradual normalization of consumption and service demand recovery amid government consumption support measures. Producer price index deflation may deepen more, reflecting low commodity prices and subdued prospects for manufacturing investment, despite improving infrastructure demand and higher industrial capacity utilization.

Reflecting labor dislocation and slower growth in household incomes, the pace of poverty reduction is expected to slow. Self-employed workers, and those in informal, less secure employment, particularly migrant workers, are especially vulnerable. Without additional policy measures, between 8 and 20 million fewer people are expected to escape poverty in 2020 (based on \$5.50/day 2011 PPP), due to the pandemicinduced slowdown. 
Table 1. China selected economic indicators (under baseline scenario)

\begin{tabular}{|c|c|c|c|c|c|}
\hline China selected indicators & 2017 & 2018 & 2019 & 2020 & $2021 f$ \\
\hline RealGDP growth, at constant market prices & 6.9 & 6.7 & 6.1 & 1.6 & 7.9 \\
\hline Private consumption & 6.8 & 9.5 & 6.8 & -1.0 & 11.5 \\
\hline Government consumption & 10.0 & 10.4 & 8.4 & 11.8 & 7.4 \\
\hline Gross fixed ca pital formation & 4.4 & 4.8 & 4.5 & 0.2 & 6.1 \\
\hline Exports, goods and services & 9.1 & 4.0 & 2.5 & -4.0 & 2.0 \\
\hline Imports, goods and services & 7.1 & 7.9 & 1.0 & -5.0 & 4.0 \\
\hline RealGDP growth, at constant factor prices & 6.9 & 6.7 & 6.1 & 1.6 & 7.9 \\
\hline Agriculture & 4.0 & 3.5 & 3.1 & 2.6 & 3.4 \\
\hline Industry & 5.9 & 5.8 & 5.7 & 2.1 & 6.3 \\
\hline Services & 8.3 & 8.0 & 6.9 & 1.0 & 9.9 \\
\hline Inflation (Private Consumption deflator) & 1.6 & 2.1 & 2.9 & 2.1 & 2.3 \\
\hline Current account balance (\% of GDP) & 1.6 & 0.2 & 1.0 & 0.7 & 0.4 \\
\hline Fina ncial AccountBalance, excl. reserves (\% of GDP) & 0.9 & 1.2 & 0.3 & 0.2 & 0.3 \\
\hline Net foreign direct investment(\% of GDP) & 0.2 & 0.7 & 0.4 & 0.2 & 0.4 \\
\hline Public finance budget balance (\% of GDP) & -2.9 & -3.4 & -2.8 & -3.6 & -2.6 \\
\hline Augmented fiscalbalance ( $\%$ of GDP) ${ }^{a}$ & -3.9 & -4.6 & -6.4 & -11.8 & -5.4 \\
\hline Primary balance ( $\%$ of GDP $)^{a}$ & -3.2 & -3.6 & -5.1 & -10.7 & -4.1 \\
\hline Government debt ( $\%$ of GDP) & 37.1 & 38.4 & 41.8 & 52.6 & 53.4 \\
\hline
\end{tabular}

Source: World Bank.

Notes: $f=$ forecast (baseline).

(a) World Bank staff calculations. The augmented fiscal balance (narrow definition) adds up the public finance budget, the government fund budget, the state capital management fund budget, and the social security fund budget.

The prima ry balance is the difference between revenue and non-interest expenditures.

\section{Risks}

Risks to China's economic outlook are unusually high. Uncertainty about the pandemic and the post-pandemic recovery, remain high (Figure 25). The range of possible growth outcomes is exceptionally wide. The ultimate outcome will depend on the evolution of the pandemic, the extent and duration of measures to stem the pandemic, the size and effectiveness of policy responses, and the spillovers emanating from major economies.

Two alternative scenarios in addition to the baseline scenario help to illustrate possible growth outcomes in China. On the downside, recurrent COVID-19 flareups could disrupt economic activity and dampen business and consumer sentiment to a greater extent than assumed in the baseline, despite efforts to suppress the spread of the virus. Externally, a

Figure 25. Global policy uncertainty (Index)

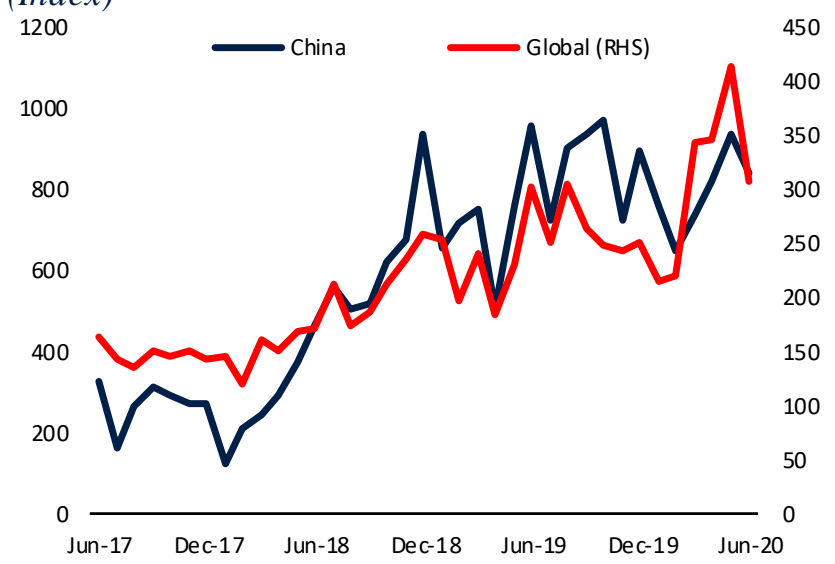

Source: Haver Analytics.

Note: GlobalEconomic Policy Uncertainty Index [Current Price GDP Weights] (Mean=100); China, News-Based Economic Policy Uncertainty Index (Mean=100). deeper and more protracted global recession and escalating bilateral tensions between China and its key trading partners could also derail the recovery. In a downside scenario, the Chinese economy could slow to 0.5 percent in 2020, and growth would remain below trend in 2021 (Figure 26). On the upside, the downturn 
this year could be less severe than the baseline forecast if domestic and global consumer and investor confidence, boosted by effective policy measures, recover faster than anticipated in 2020Q3. In an upside scenario, full-year GDP growth in China is projected at 2.2 percent in 2020 (Figure 26.A). A de-escalation of economic tensions between China and the United States would provide additional boost to GDP growth both this year and in 2021.

\section{Figure 26. Growth projections under three alternative scenarios}
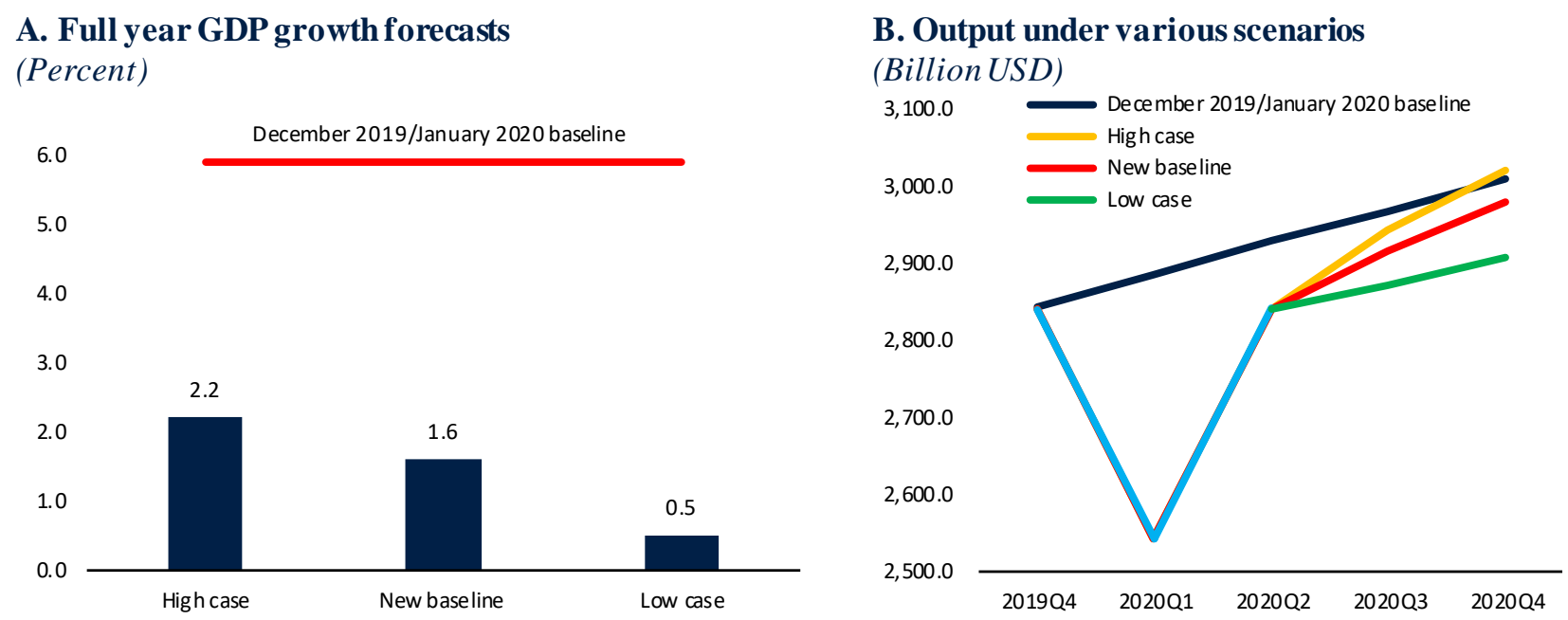

Source: Ha ver Analytics; World Bank.

Note: A. December 2019/January 2020 baseline refers to GDP growth projections published in the World Bank December 2019 China Economic Update (World Bank 2019) and in January 2020 Global Economic Prospects report (World Bank 2020d). B. Billion 2015 US dollars, quarterly seasonally a djusted. Data for 2020Q3-Q4 are forecasts.

The main downside risk is related to the possibility of a longer-lasting pandemic with more serious effects than assumed under the baseline scenario. Recurrent outbreaks could occur at a wider scale than assumed in the baseline cause more significant economic disruption both in China and the rest of the World. Such adverse developments would delay full resumption of activity, impair the recovery, and hinder the effectiveness of the stimulus measures.

A more significant spike in bankruptcies and corporate distress could also lead to a slower recovery. Financial vulnerability could amplify downside risks. Slower growth may uncover deep-seated financial vulnerabilities and cause more disruptive deleveraging of corporate and banking sector balance sheets. Despite the resilience of Chinese financial markets during the pandemic, previous stress episodes show that China is not immune to financial market turbulences. Despite the recent strong rebound in financial market sentiment, the remaining uncertainty around the underlying economic prospects, points to the possibility that financial conditions may tighten more than assumed in the baseline. Continued defaults in local and regional banks or in large segments of the shadow banking system, an abrupt adjustment in property prices, or sudden sizable outflows of capital-combined with a sharp correction in asset prices - all could propagate through the highly leveraged financial system. This would exacerbate existing balance sheet weaknesses in China's highly leveraged banking, corporate, and household sectors (World Bank 2020a). Corporate and household sector deleveraging could weigh heavily on private investment and consumption, and act as a persistent drag on activity, as is commonly the case following periods of rapid debt accumulation (Kose et al. 2019).

External risks to the outlook are also significant. A deeper and more protracted global recession, heightened policy uncertainty, as well as escalating tensions and potential selective decoupling between 
China and major advanced economies could derail the recovery by hindering confidence, trade flows, and investment, and causing disruption of global value chains (Figure 25). Such an adverse development could also harm potential growth by restricting access to imports of critical technology (Boxes 4 and 6; World Bank forthcoming; World Bank 2016a; DRC and World Bank 2019). The outbreak has exposed significant vulnerabilities to global supply dependence, which may exacerbate decoupling in a post-COVID-19 world (World Bank 2019; World Bank 2020b). Persistent policy uncertainty, for example, due to renewed economic tensions between major economies, could dampen the recovery of confidence, investment, and trade.

On the upside, China may continue to recover faster than expected from the pandemic fallout. The orderly removal of control measures could result in the stronger-than-expected recovery of consumer and investor confidence. This, coupled with the effective fiscal, monetary, and structural reform policy efforts could lead to a more rapid recovery in employment, unleash pent-up demand, and promote a faster economic recovery than projected in the baseline scenario. This scenario also assumes no further escalation of trade tensions between China and the United States. In this scenario, consumer and investor confidence could surge, boosted by significant and effective fiscal support measures. Domestic demand would offset the negative impact of contracting exports in 2020Q3. The ensuing global economic rebound would be steeper, as pandemic-control measures are largely lifted, and fiscal and monetary policy responses succeed in containing the contraction in global activity this year to around 4 percent. The faster recovery implies there is significantly less damage to potential growth than in the baseline (Box 6).

Finally, there are risks associated with a prolonged credit-fueled public-investment-led recovery. The nature of the recovery will ultimately determine its sustainability and longer-run outlook for China. A faster than expected recovery of headline GDP growth driven mostly by public investment is possible, but this would exacerbate internal and external imbalances, result in excess capacity and higher debt, which would weigh on China's medium-term outlook.

\section{Box 6. Impact of COVID-19 on the output gap and potential growth in China ${ }^{18}$}

This box will answer the following questions:

- What are the supply and demand dynamics of COVID-19 on China?

- How large will the output gap be?

- What may happen to potential growth?

Temporary shocks. The demand and supply dynamics of COVID-19 have both short-term and long-run consequences. Potential growth - the supply-side - is typically thought of as a smooth and slow-moving process. If this were true, then all the short-term ups and downs in output growth would be demandrelated and would shift the output gap. ${ }^{19}$ In reality, short-lived supply shocks can be common occurrences, especially in EMDEs, including drought, oil production disruptions, and strikes (Botha et al. 2018). These events lead to a temporary loss of supply, whether of commodities or labor, which should increase prices and leave the output gap unchanged. Macroeconomic policy is generally ineffective in responding to these developments. In the case of COVID-19, activity in China has normalized somewhat following a major contraction, as disruptions to business operations receded, businesses opened, and

\footnotetext{
${ }^{18}$ Written by Franz Ulrich Ruch.

19 The output gap measures the difference between what an economy is producing and what can be efficiently produced at full capacity, generally referred to as potential output. As a concept, it is synonymous with the business cycle - the ups and downs, expansions and contractions, or booms and busts that occur over a number of years.
} 
workers were able to return to workplaces. The pandemic-related supply disruptions were thus mostly short-term in nature and should have short-term consequences for potential growth.

There are also short-term demand consequences related to the outbreak. Workers who were temporarily out of work without income have since been able to return to work and start purchasing goods and services. Businesses that were unable to provide inputs to production are now better able to sell their products.

Long-run losses to potential growth. Unfortunately, history suggests that the economic consequences of this pandemic are unlikely to be only short-term in nature. ${ }^{20}$ COVID-19 represents the largest contraction in global output in post-war history, and recessions of this nature are associated with persistent losses in output (World Bank 2020d). The pandemic-related fallout will also likely be the most synchronized slowdown in economic history, with more than 90 percent of economies experiencing a recession-more than during the Great Depression. Economies are therefore unlikely to be able to find demand elsewhere. Recessions, especially those accompanied by financial crises, cause long-term losses to potential output (World Bank 2020d). For EMDEs, the output loss is estimated at almost 8 percent in the five years following the recession.

In the current context, the pandemic is likely to dampen capital accumulation as expected returns on investment decline due to a higher policy uncertainty, lower expected growth, and weaker business confidence. Investment growth in China will likely decelerate further, offset only partly by public investment. The pandemic has also highlighted the risks associated with the design of global supply chains. These global linkages, an important engine of growth over the previous few decades, may go through costly reconfigurations. Households facing rising uncertainty are likely to increase precautionary savings and change their spending behavior. If unemployment remains elevated it could cause losses to human capital and reduce job-search activity. Productivity is also expected to suffer as innovation slows.

Output gap and potential growth in the baseline. Reflecting the temporary part of the COVID-19 shock, growth in China contracted by 36 percent on an annualized quarter-on-quarter basis in the first quarter of 2020, before rebounding by 56 percent in the second quarter. Full year growth is expected to be 1.6 percent for 2020, slowing precipitously from 6.1 percent in 2019. The impact in the first half of 2020 was both a demand shock, leading to a widening output gap, and a temporary supply shock, which decreased potential growth. A decomposition of growth in $2020 \mathrm{H} 1$ suggests output was mainly a supply shock (Figure 27.A). For the full year, about 60 percent of the projected 1.6 percent growth in 2020 is expected to come from a rebound in production.

The temporary shift in supply from the disruption to production and service provision suggests that potential growth in the first quarter also dropped sharply (Figure 27.B). However, as the situation normalizes, and production is further ramped up to catch-up lost output, potential growth should receive a boost. Reflecting the partly temporary nature of the supply shock, potential growth is expected to be below 5 percent in 2020, rebounding to over 6 percent in 2021.

The COVID-19 outbreak also represents a significant demand shock to the economy. While the output gap was effectively zero for most of the last three years, it widened significantly in the first quarter of 2020. The second quarter rebound has made up some of these losses but the output gap for 2020 is still expected to average around -3 percent of potential output, and narrow but remain negative in 2021

\footnotetext{
${ }^{20}$ Evidence of the long-term economic consequences of pandemics is limited (McKibbin and Fernando 2020). The economic consequences of recessions and crises provide some guide for the future (Wor ld Bank 2020d).
} 
(Figure 27.C). This is significantly worse than the output gap registered during the global financial crisis and implies that demand is the main constraint to output recovery in the short run.

Uncertainty about the exact size of deficient demand. The ultimate impact of COVID-19 is highly uncertain. Alternative growth scenarios provide useful insights for assessing various possible outcomes. Under a high case scenario, China experiences a rapid and sustained recovery where consumer and business confidence surge. The output gap in this scenario is estimated at -2.5 percent of potential output in 2020. The projected strong and sustained recovery means that the output gap will be effectively closed in 2020Q4 and be slightly positive for 2021. Under a low case scenario, reoccurring localized outbreaks, weaker consumer and investor confidence, as well as a more challenging external environment will result in the output gap widening to -3.5 percent in 2020 with little improvement expected in 2021.

Lower potential growth. Beyond the short-term shifts in supply due to the pandemic, the longer-run outlook for China is uncertain but likely worse than expected prior to the pandemic. EMDEs that have faced a recession-cum-crisis in the past saw an 8 percent loss in potential output, compared to baseline, in the five years after the recession, with more vulnerable EMDEs likely to experience greater losses (World Bank 2020d). While losses in China are likely to be lower, given available policy space and the limited likelihood of a financial crisis, potential growth three years after the initial contraction is still likely to be between 3.0 and 5.4 percent, lower than what was expected prior to the pandemic. This represents a loss in potential output over three years of anywhere between 6.5 and 0.1 percent, compared to the pre-COVID-19 baseline (Figure 27.D).

\section{Figure 27. Coronavirus impact on output gap and potential growth}

COVID-19 is both a supply and demand shock, leading to temporarily lower potential growth and a wider output gap. If downside risks materialize, the output gap could be significantly larger, and potential growth losses permanent.

\section{A. Output growth decomposition (q/q saar, percent)}

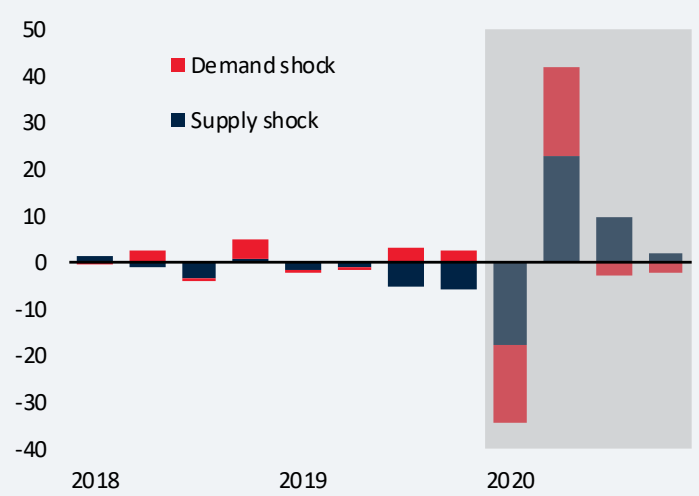

C. Output gap

(Percent of potential output)

\section{B. Output and potential growth $(y / y$, percent $)$}

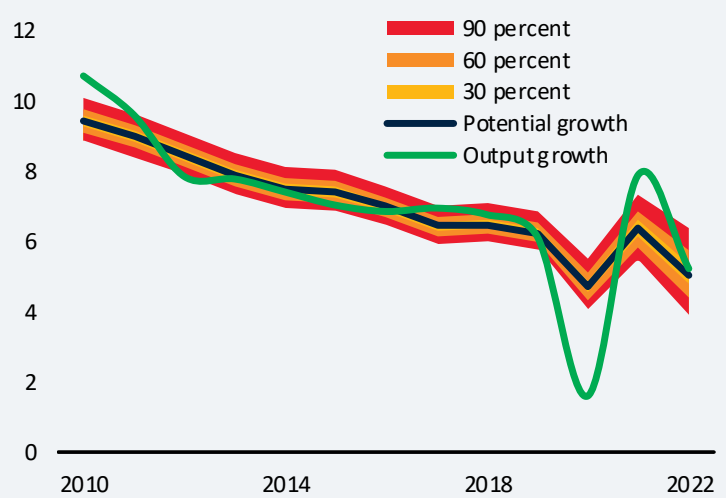

D. Potential output, deviation from the previous baseline

(Percent) 


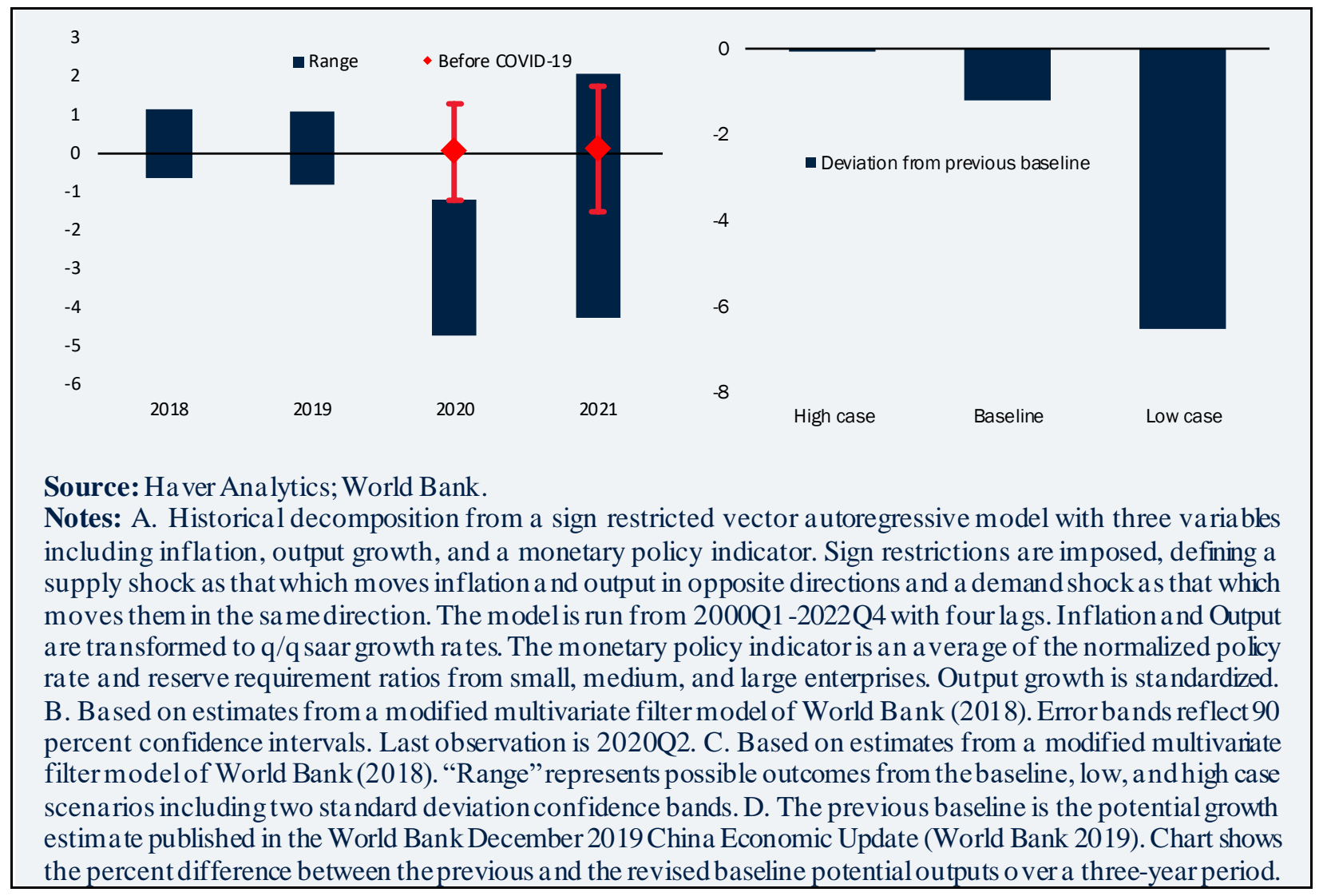

\section{Policy considerations}

While risks are exceptionally high, they can be partially mitigated by good policies. The authorities face the complex challenge of ensuring sustained containment of COVID-19 while allowing economic activity to recover and mitigating downside risks to growth. Public health and pandemic control measures, including large-scale testing, contact tracing, and case isolation, are crucial to reducing the risk of second wave outbreaks during the resumption of economic and social activity. On the economic front, the situation calls for a macroeconomic policy mix aimed at rebuilding confidence and augmenting domestic demand, but designed in a way to support a rebalancing to a greener and more inclusive economy. Decisive steps to foster global cooperation and further expand openness to trade and investment would help reduce tensions with trading partners and preserve and deepen China's integration into the global economy.

Monetary policies should remain accommodative to ensure abundant liquidity and keep market rates and bond yields low. Subdued inflationary pressures are expected to continue in the immediate future, given that the demand shock will likely outweigh and outlast the supply shock. Commodity prices, especially, are already at historical lows, benefitting China as a net importer. In addition, major central banks across the world have cut policy rates in response to the crisis. Against this backdrop, there is room to keep monetary policy in China accommodative without triggering inflation risks and/or capital outflows. Accommodative policies would ensure abundant liquidity and keep market rates and bond yields low. This would ease financing conditions and the debt burdens of households, businesses, and banks.

Fiscal policy will need to play a critical role in supporting the recovery of domestic demand. Stretched balance sheets and high levels of uncertainty mean corporate investment and household spending may remain subdued even if financing conditions continue to be accommodative. This puts an additional impetus 
on fiscal policy to support aggregate demand. China does have space to respond, especially at the national level. Still, stimulus measures would need to be designed in a way that also contributes to China's mediumterm objectives of rebalancing the economy to more inclusive, greener, and consumption-driven growth.

\section{1) Protecting people and livelihoods}

Investing in social safety nets to mitigate social impacts and support rebalancing toward a more inclusive and consumption driven economy. The crisis has exposed gaps in China's social protection system, including the limited coverage of migrant workers, who have been heavily affected by the COVID shock. Building on COVID-driven steps to reinforce social safety nets, there are opportunities for China to enhance the role of social protection by both supporting the recovery and achieving the goal of eradicating extreme poverty by the end of the year. This would not only help protect workers and households from the distress caused by job and income losses but also mitigate lasting weakness in private consumption. In the short term, China could use budget financing to expand social protection coverage and benefit adequacy of key programs, including the Dibao and rural pension benefits. In addition, enhancing the use of job loss insurance claims, providing more funding for active labor market programs and training, and expanded loan guarantees to support entrepreneurship all would be conducive to mitigating labor market impacts. Over the medium term, social security holidays which have created incentives for firms to maintain employment levels will need to be phased out. With the economic recovery, the government should continue its reform of the social security system. This includes parametric reforms to ensure financial sustainability and to make room for a reduction of social security contribution rates, especially for low income workers, stimulating formal employment and helping lay the foundation for extending coverage of the formal system to the entire urban labor force. Part 2 of this report provides a more detailed assessment of the social and distributional impacts of the COVID shock and policy options to mitigate them.

In addition, using consumption vouchers, as many Chinese cities and provinces already do, could lift consumer spending in the short term. Vouchers could have a large multiplier effect, if targeted to hardhit service sectors that are labor intensive, such as hospitality, restaurants, or traditional retail activities. Excessively narrow targeting to specific products should be avoided. As a matter of design, vouchers should expire before the end of the year (or earlier) to encourage a frontloaded consumer response and avoid quasisavings. Targeting such support to lower income households would also help mitigate social and poverty impacts.

\section{2) Advancing structural reforms for a stronger and more sustainable recovery}

Structural policies should focus on enabling the reallocation of resources and facilitating adjustments to the post-pandemic economic realities. Supporting firms, especially small and medium sized enterprises, remains a priority. China's corporate sector has been severely impacted by the sharp slowdown, especially small and medium size enterprises that account for a considerable share of employment. For small and medium enterprises, income support and cash grants could be targeted directly to entrepreneurs to mitigate associated income and social stresses. For large enterprises, incentives to retain employment, such as social security contribution holidays and ample liquidity from the banking system, may need to be maintained, although with a clear exit strategy to avoid locking employment in unproductive jobs. As financial lifelines to firms are unwound, structural policies should enable the reallocation of resources and facilitate the adjustment to the post-COVID economy. If corporate distress reflects deeper underlying solvency (rather than liquidity) issues, such as over-leveraged balance sheets, strengthening the insolvency system can facilitate recovery as a channel for resolving debt-overhang and preserving employment. Intensifying "hukou" (household residency registration system) reform and enhancing access to and portability of social services would ease the movement of labor from firms and sectors suffering more persistent damage to expanding sectors, firms, and locations. Further enhancing market access, including 
in the relatively closed service sectors, could boost investment and accelerate knowledge and technology diffusion, and also help ease lingering geo-economic tensions that may be further exacerbated by the pandemic-induced recession.

\section{3) Greening the infrastructure stimulus}

Infrastructure investment should be designed to support China's transition to a low carbon and more resource efficient economy. Public investment has traditionally played an important role in countercyclical fiscal policy. Fiscal multipliers of infrastructure spending are generally strong because of the labor intensity of delivering infrastructure. Indeed, if public investment lifted infrastructure investment growth to 10 percent (from last year's 3.8 percent), it would hike short-term growth by about 0.7 percentage points. However, long-term returns on traditional infrastructure assets - transportation and real estate - have diminished. In a similar vein, investments in carbon-intensive infrastructure, such as coal-fired thermal power plants, are unlikely to generate adequate long-term returns, as these assets will likely be stranded before being fully depreciated economically. By contrast, there are advantages to targeting next-generation and green infrastructure, especially. The benefits could include investments in energy efficient housing retrofits and rooftop solar installations, especially of public buildings (office buildings, schools, hospitals, etc.), as well as electric vehicle charging infrastructure, soil restoration, reforestation (which could be combined with eco-service compensation payments to households), green city infrastructure, etc. These would not only boost demand, they would support China's transition to a low-carbon economy. Public investment could be combined with commitments to regulatory and tariff reforms to enhance the long-term financial viability of these investments and stimulate private investment in environmental in frastructure.

\section{4) Ensuring stability}

Emerging financial sector risks need to be managed carefully while ensuring that the flow of credit to the real sector is not impeded. As such, the various measures currently in place should be carefully monitored for unintended consequences, such as the creation of new financial vulnerabilities. For instance, regulatory forbearance on recognition of NPLs should be truly temporary and not unduly prolonged. This will avoid moral hazard for banks and their clients and facilitate the timely recognition of expected losses. ${ }^{21}$ If the expected surge in NPLs materializes, CBIRC should allow banks to use available capital conservation and countercyclical buffers to absorb losses. There is also a need to monitor provisioning and loan loss reserves closely to make sure they are in line with the evolution of credit risks and potential loan losses. While the establishment of subsidized special lending programs for businesses affected by the outbreak will provide relief to borrowers, the overall credit risk is rising, since many of the borrowers may be too troubled to recover and repay. Banks may also be tempted to relax loan underwriting criteria for the new loans granted under the special lending programs. For this reason, good credit risk management practices are essential to avoid sowing the seeds for future deterioration in asset quality. To avoid eroding credit discipline for borrowers and increasing moral hazard among lenders, government loan guarantees should not provide 100 percent coverage. ${ }^{22}$ The particular vulnerabilities of small and medium-sized banks suggest that they will require some form of balance sheet support if loan losses are substantial.

\section{5) Enhancing pandemic preparedness and resilience}

China has managed to contain the COVID-19 outbreak for now. But the pandemic has revealed shortcomings in disease surveillance and control. The crisis offers an opportunity to close these gaps by

\footnotetext{
${ }^{21}$ See (World Bank-International Monetary Fund. 2020).

22 The urgency of putting relief measures in place makes it difficult to distinguish between companies that were viable preCOVID and can recover vs. those that cannot recover even with the various aid measures in place.
} 
moving decisively towards a One Health approach, based on multi-sectoral cooperation in mapping and reducing public health risks, active case-based surveillance and timely reporting, improved surge capacity and strengthened international collaboration (Box 7).

\section{Box 7. Implementing a One Health approach for emerging infectious diseases ${ }^{23}$}

Emerging infectious diseases (EIDs) with pandemic potential are a major threat to global health security. About 60 percent of all infectious pathogens of humans originate from animals and some 70 to 75 percent of emerging infectious diseases in humans originate in animals. Approximately 2.5 billion zoonotic infections occur in humans every year globally, causing at least 2.2 million human deaths, especially in low-and middle-income countries. The rate of emergence of infectious diseases with zoonotic origin has increased over the past decades. Prominent examples include AIDS, Ebola and Marburg hemorrhagic fevers, Escherichia coli O157 infection, Middle East respiratory syndrome coronavirus (MERS-CoV), and Severe Acute Respiratory Syndrome (SARS).

China is a hotspot for EIDs. First, China's livestock industry is one important risk factor for EIDs. Animal production in China is dominated by intensive production systems, accounting for 44.4 percent of pig production, 49.95 percent of dairy cattle rearing, and 65.4 percent of broiler chicken production as of 2016. A second risk factor is increased human and animal exposure to wildlife, driven by habitat fragmentation and loss, wildlife poaching, trade and consumption. A third important risk factor are shortcomings in food safety and sanitary practices, along the value chain from production to final consumption. China's agricultural sector, while highly intensive is also largely fragmented, creating challenges for effective supervision and control over agricultural practices

The COVID-19 crisis has invigorated the policy reform agenda to address the shortcomings in disease surveillance and control revealed by the outbreak. Addressing the social, environmental and economic determinants of EIDs calls for multisectoral responses - often referred to as the One Health Approach. Characteristic of this approach is the multidisciplinary and cross-sectoral collaboration to identify risks of infectious diseases at the animal-human ecosystem interfaces.

$\mathrm{OH}$ is an interdisciplinary and inter-sectoral approach covering human health, animal health, and environmental health, with a focus on infectious disease-related issues (including AMR) that undermine overall human health and well-being. International experience highlights the importance of integrated and multisectoral approaches to effectively identify and control the risks of EIDs. For instance, the European Union is implementing a program on non-foodborne zoonotic and potential zoonotic diseases with coordination at the animal-human interface. The success of the $\mathrm{OH}$ approach depends upon changes in cultural, social and institutional practices, at an institutionalized and systemic level. It is thus an effort that needs to be sustained over time and its implementation requires local level engagement and support, including by frontline public health and primary health care workers.

The Healthy China 2030 Plan outlines basic strategic directions consistent with the $\mathrm{OH}$ approach. Several recent legislative initiatives covering infectious diseases, biosecurity and wildlife protection are expected to provide a stronger legislative framework for implementing $\mathrm{OH}$. Nonetheless, implementation challenges remain and will require continued attention of policy makers in the following four areas: i) implementing Health in All Policies (i.e. making concerns for human health a cross-cutting government responsibility); ii) putting prevention first; iii) building systems back better by strengthening the capacity of health and food systems to address future disease threats; and iv) creating partnerships. Based on these

\footnotetext{
${ }^{23}$ Prepared by Dinesh Nair and Wei Han.
} 
broad principles, China could develop a concrete $\mathrm{OH}$ program by identifying entry points to prevent, detect, and respond to specific EIDs and other health risks; developing risk-based early warning systems; developing action plans for health risk prevention in identified priority areas; and creating institutional mechanisms for cross-sectoral collaboration in joint risk mapping, monitoring and evaluation, disease surveillance and response and health research and development.

Practicing $\mathrm{OH}$ to reduce the risk of emerging health threats could bring substantial economic benefits. According to a World Bank estimate, annual investment of US\$ 1.9-3.4 billion in low- and middleincome countries for effective disease control via $\mathrm{OH}$ approaches would yield as much as $\$ 37$ billion in savings from reduced epidemics and pandemics - a net gain of about $\$ 34$ billion annually. Investing in One Health Approaches is cost-effective both because of effective risk mitigation and because the efficiency of collaborative approaches is considerably higher than each sectoral department pursuing disease surveillance and control measures on their own.

\section{6) Fostering openness and international cooperation}

As the second-largest economy in the world, China can play an important role in fostering global cooperation. This includes collaboration in public health matters but also extends to the economic sphere. Preserving open and balanced trade and investment relationships with rest of the World would boost investment and accelerate knowledge and technology diffusion, and also help ease lingering geo-economic tensions that may be further exacerbated by the pandemic-induced global recession. 


\section{Assessing the Distributional and Labor Market Impacts of COVID-19 in China}

The COVID-19 pandemic has greatly impacted economic growth, job creation, and income generation in China. To contain the virus' spread, China locked down cities and closed all non-essential economic activities nationwide. Those strict measures disrupted normal production and employment activities and hit China's economic growth and job creation hard, as discussed in the previous chapters of this report. ${ }^{24}$

In the first three months of the year, households experienced a severe shock as a result of COVID19. Compared to the same period of 2019 during the first quarter of 2019, per capita disposable income dropped by 3.9 percent (Figure 28.A). Real income losses were larger for rural than urban households, with both business and wage incomes falling over 6 percent. Urban households, by contrast, saw a much larger drop in business incomes (-17 percent), but the loss from wages was less pronounced ( -3 percent). The relatively lower losses for wage income may reflect, in part, the role of the public sector and firms absorbing some of the shortfalls. Transfers (private and public) grew slightly (about 2 percent), lessening the overall income fall to some degree.

Household expenditure fell substantially more than disposable income. Per capita consumption expenditures declined by 12.5 percent in 2020Q1 (Figure 28.B), indicating households became more cautious and adjusted their spending more than proportionally to the falloff in per capita disposable income. The fact that the large declines were in clothing, entertainment, and transportation suggests that household spending may have been curtailed over and above the precautionary savings motive, as a direct result of the nationwide lockdown that mandated people stay at home and stores close. Still, food expenditures for both urban and rural households also dropped considerably (-15.0 and -8.5 percent, respectively). The decline suggests that income losses and rising food prices early in the year (particularly for pork, fresh vegetables, and fruits) may have affected particularly poor and vulnerable households, driving them to cut back on essential spending.

\footnotetext{
${ }^{24}$ See (National Bureau of Statistics China. 2020).
} 
Figure 28. Per capita household disposable income and expenditure

During the first quarter of 2020, household expenditures fell significantly more than disposable income

A. Per capita disposableincome

(PercentagechangeQ1 2019-Q1 2020)

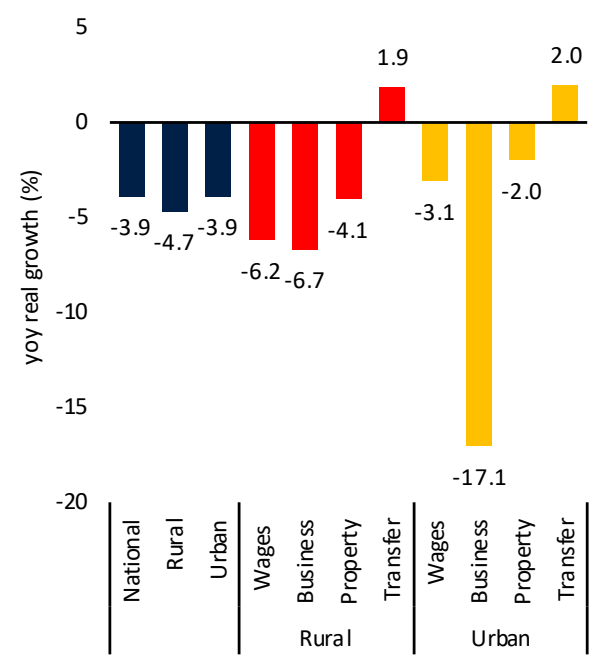

C. Per capita disposable income

(PercentagechangeQ2 2019-Q2 2020)

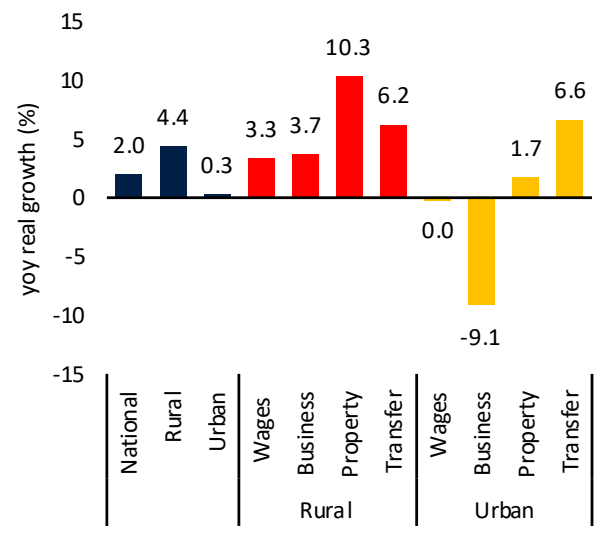

B. Per capita household expenditure

(Percentage changeQ1 2019-Q1 2020)

20

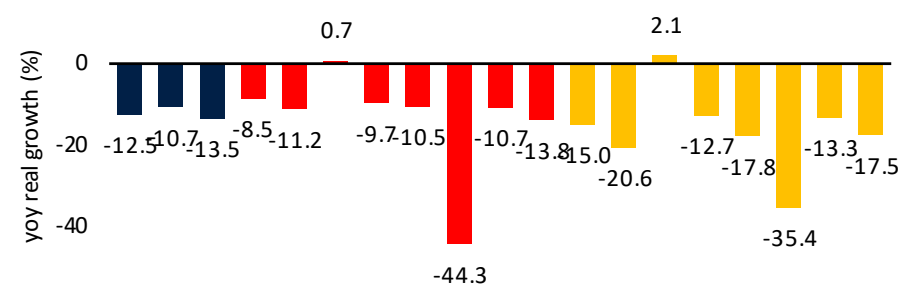

$-60$

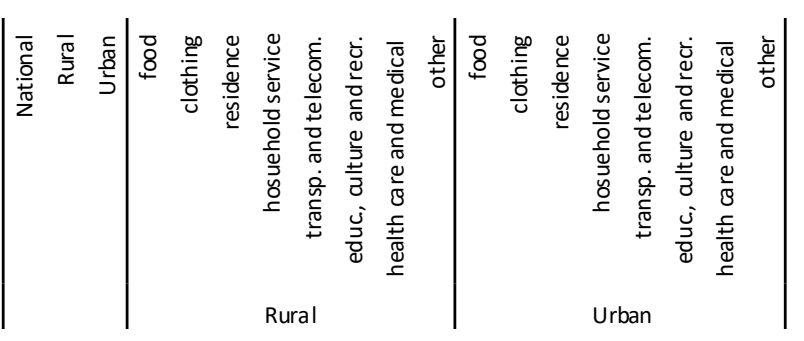

D. Per capita household expenditure

(PercentagechangeQ2 2019-Q2 2020)

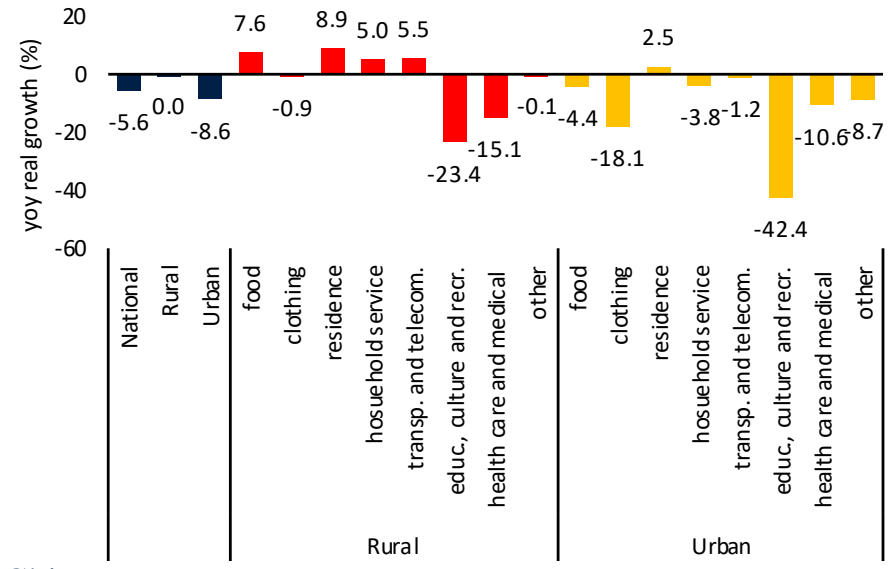

Source: Da ta from Na tional Bureau of Statistics China.

Note: In Pa nel A and C, income changes are expressed in real terms, using rural and urban Q1 a verage consumer price indices. In Panel $\mathrm{B}$ and $\mathrm{D}$, changes in expenditures are expressed in real terms using price changes by category of expenditure in urban and rural a reas.

Averages hide differences in the losses incurred across the distribution. While there is no available official information on expenditure/income changes across the welfare distribution, recent evidence suggests that those earning less than RMB 50,000 per year expect larger declines in their annual income (around 31 percent) and consumption ( 22 percent) than those above this threshold (20 and 15 percent, 
respectively). ${ }^{25} \mathrm{Job}$ stability has fallen more for low and middle-income families than their better-off counterparts. ${ }^{26} \mathrm{~A}$ survey in February and March of rural areas suggested sizeable declines in incomes from employment in the first months of the lockdown, due in large part to restrictions that barred the return of migrants to their places of work. About half of the villages in the survey reported average losses in February of RMB 3,000 per family (equivalent to a 25 percent decline in average per capita income in rural areas), and the majority of villagers were reducing their food expenditures. ${ }^{27}$ Faced with a reduction in incomes, families drew on their savings, but poorer ones cut spending on purchases of meat, vegetables, and fruits, which could have severe implications for future nutrition, particularly among children.

As incomes recovered in the second quarter of 2020, household expenditures continue to lag. Disposable incomes in rural areas grew 4.4 percent in 2020Q2 relative to the same quarter the previous year, as all sources of household incomes recovered (Figure 28.C). However, for those living in urban areas business incomes continue to decline (by 9 percent) and wages were stagnant. With almost no growth in disposable incomes, urban households continued to restrict their consumption, particularly of services and clothing, leading to an overall decline in per capita expenditure of 8.6 percent (Figure 28.D). Food expenditure among rural households has recovered, as has transportation and household services suggesting that activity is resuming. Yet, expenditure on education, recreation and health care remains significantly below the same period the previous year.

\section{Expected distributional impacts for 2020}

The distributional impact of the COVID-19 shock is largely a function of a differentiated impact across economic sectors and occupations. The following paragraphs present the results of a microsimulation, imposing different income shocks across sectors of the economy depending on the projected difference in pre- and post-crisis 2020 growth rates, and taking into account average income levels precrisis by sector of employment or type of occupation. The basic finding is that the biggest impact of COVID-19 is experienced by people in the middle of the pre-crisis income distribution. This implies that the crisis may have created a cohort of "new poor", mostly in urban areas, and only imperfectly captured by the government's existing poverty reduction efforts, largely focused on the rural poor.

Labor market disruptions have disproportionately affected informal workers, vulnerable sectors, and migrant laborers. Macroeconomic projections for 2020 suggest that economic sectors will be affected differently by the pandemic. The hardest hit sectors in the economy include hotel and catering, and wholesale and retail trade. These sectors have a disproportionate share of informal workers and a high portion of the self-employed (Table 2). On average, two-fifths of workers in highly affected sectors are self-employed, and over half do not contribute to social security or have signed employment contracts. Lacking standard labor protection and access to benefits such as unemployment insurance, they are more vulnerable to losing their earnings as activity sharply declines. Migrants, who represent 30 percent of the total labor force in urban areas, ${ }^{28}$ are disproportionally concentrated in these sectors as well. In addition,

\footnotetext{
${ }^{25}$ See (Gan, L. 2020). Prof. Li Gan presentation on June 5, 2020 at the online Seminar on Poverty Reduction, organized by International Poverty Reduction Center in China, Bill and Melinda Gates Foundation and Amsterdam Institute for Global Health and Development. Based on a special subsample of the China Household Finance Survey (panel), collected between February and May 2020.

${ }^{26}$ Ibid.

${ }^{27}$ See (Rozelle, S., H. Rahimi, H. Wang, and E. Dill. 2020). Based on a survey of 726 randomly selected village informants across seven rural Chinese provinces outside Hubei, as part of the Rural Education Action Program at Stanford University. Results cited also from presentation at the Stanford Freeman Spogli Institute on May 3, 2020 https://www.youtube.com/watch?v=HnujCSsg6OQ

${ }^{28}$ NBS data for 2018.
} 
new entrants to the labor market (around 9 million are estimated to graduate from college this year) might be less likely to find a job than in previous years, as job creation is expected to decelerate.

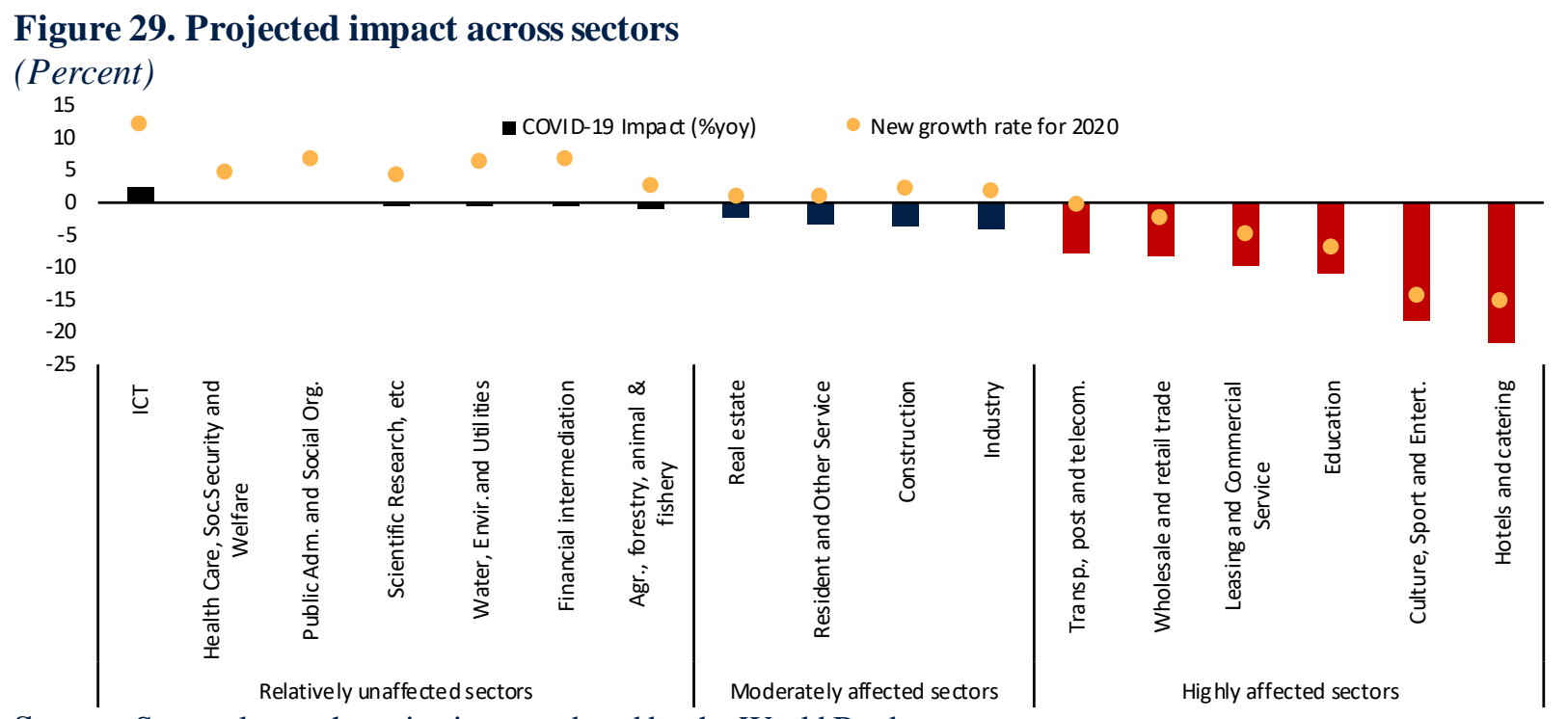

Source: Sectoral growth projections produced by the World Bank team.

Note: colors of the bars reflect groupings of rela tively unaffected sectors (black), moderately affected sectors (blue), and highly affected sectors (red).

Table 2. Selected employment characteristics, by economic sectors

Workers in highly affected sectors are more likely to be informal

\begin{tabular}{|c|c|c|c|c|c|}
\hline $\begin{array}{c}\text { Profile (pre-crisis) by Groups of } \\
\text { Sectors }\end{array}$ & $\begin{array}{l}\text { Distribution } \\
\text { of } \\
\text { employment } \\
\text { across sectors }\end{array}$ & $\begin{array}{l}\text { Share of wage } \\
\text { employment } \\
\text { (over total } \\
\text { sector } \\
\text { employment) }\end{array}$ & $\begin{array}{l}\text { Informality } \\
\text { rate among } \\
\text { wage } \\
\text { workers }\end{array}$ & $\begin{array}{l}\text { Informality } \\
\text { rate among } \\
\text { self-employed } \\
\quad \text { workers }\end{array}$ & $\begin{array}{l}\text { Share of wage } \\
\text { workers } \\
\text { without } \\
\text { contract }\end{array}$ \\
\hline \multicolumn{6}{|l|}{ Highly affected sectors } \\
\hline $\begin{array}{l}\text { Hotel and catering, Wholesale and Retail, } \\
\text { Transportation, Construction, Culture and } \\
\text { entertainment, Education, Leasing and } \\
\text { commercial activities }\end{array}$ & $34 \%$ & $60 \%$ & $56 \%$ & $50 \%$ & $60 \%$ \\
\hline \multicolumn{6}{|l|}{ Moderately affected sectors: } \\
\hline $\begin{array}{l}\text { Manufacturing, Mining, Electricity, } \\
\text { Residential services, Real Estate }\end{array}$ & $25 \%$ & $67 \%$ & $47 \%$ & $32 \%$ & $48 \%$ \\
\hline \multicolumn{6}{|l|}{ Relatively unaffected sectors: } \\
\hline $\begin{array}{l}\text { Agriculture, Financial intermediation, } \\
\text { Public Adm. and social org., Health care } \\
\text { soc. security and welfare, Water and } \\
\text { utility, ICT, Scientific Research }\end{array}$ & $41 \%$ & $23 \%$ & $32 \%$ & $31 \%$ & $47 \%$ \\
\hline Total & $100 \%$ & $46 \%$ & $48 \%$ & $42 \%$ & $53 \%$ \\
\hline
\end{tabular}

Source: Sectors grouped according to NBS national accounts data. Em ployment estimates a re from the China Family Panel Study 2018 (see Box 8 for details).

Note: The informality rate is defined as not contributing to social in surance. The alternative definition of not having a contract is provided a a complementary measure. 
Workers engaged in acutely and moderately affected sectors were more likely to be relatively welloff before the crisis. The service sector in urban areas has been a locus of job creation recently and has attracted better educated and more highly paid workers. Meanwhile, agricultural wage and income growth has lagged other sector prior to the crisis, depressing incomes of workers in these sectors towards the bottom of the distribution. According to data for 2018, poor households tend to rely more heavily on incomes from agriculture. Yet, agriculture is not expected to be as affected by the COVID-19 crisis as services and construction. Instead, households in the upper half of the distribution are typically more engaged in these highly-affected sectors (Figure 30).

\section{Figure 30. Share of households engaged in each of the sectors}

Households in the middle and upper part of the distribution are more engaged in the highly affected sectors

A. National

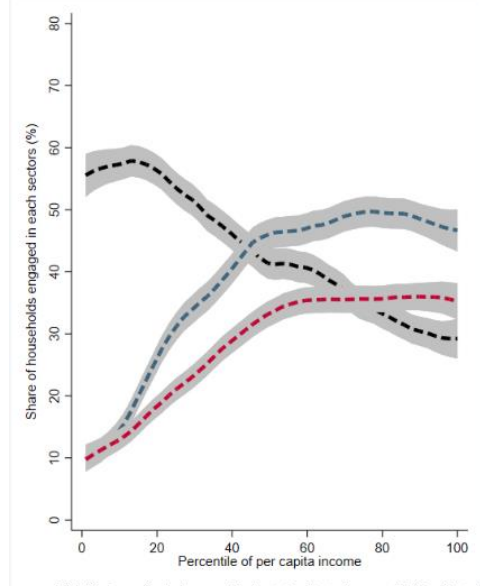

B. Urban

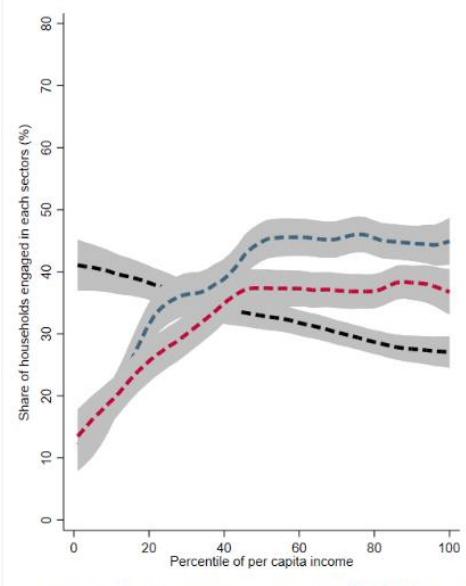

C. Rural

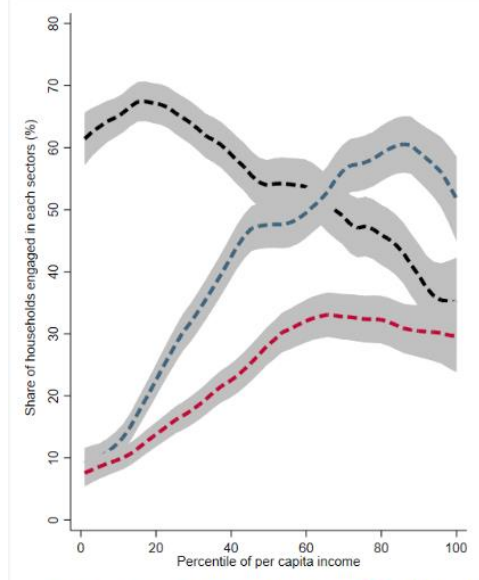

Source: China Family Panel Study 2018.

Note: Sectors defined as in Table 2. Grey areas indicate 95 percent confidenceintervals.

Informal workers and the non-agriculture selfemployed (who are likely to see their earnings fall the most), are disproportionately concentrated in sectors facing the largest impact. In the first quarter of 2020, business incomes in urban areas fell five times more than wage earnings. Within the highly affected sectors, income from informal work represents more than half of total non-agriculture labor incomes among households in deciles 3 to 6 (Figure 31). In cases where such earnings are the main income source in the family, losing a couple of months of income may be sufficient to push them into the poorest two deciles. While women are less likely to work in highly impacted sectors, they may be more vulnerable within sectors because a disproportionally larger share of the self-employed are women, particularly in wholesale and retail and hotel and catering activities. In crises, they face higher risks of losing their incomes.

\section{Box 8. Data source}

Since access to official household survey data is not available, the analysis in this section relies on the 2018 China Family Panel Study (CFPS). The survey is a nationally representative, biennial longitudinal survey of Chinese communities, families, and individuals, launched in 2010 by the Institute of Social Science Survey (ISSS) of Peking University, China. The present analysis uses the cross-sectional sample (over 9,000 households and 20,000 individuals). Data is publicly available at the CFPS website:

https://opendata.pku.edu.cn/dataverse/CFPS? $\underline{\text { language }=\text { en }}$ 
Migrant workers have also been disproportionally affected by the lockdown. The lockdown of cities put thousands of stranded migrants into difficult situations and in need of emergency help. During the outbreak, most rural migrant workers happened to be visiting their hometowns for the Chinese Spring Festival. With the lockdown, millions of these workers remained in the countryside and had difficulty returning to work. To some extent, this may have contributed to reducing the unemployment pressure in the urban labor market, but it also negatively impacted families relying on remittances. Incomes from migrants represent a third of household incomes among those just above the bottom quintile of the distribution. Those who had often been the main breadwinners of these families have become dependent on other family incomes, as opportunities for gainful employment in their places of origin were limited. In addition, migrant workers in urban areas are more likely to be engaged in some of the most affected sectors.

\section{Figure 31. Share of total household income by source}

Poorer families depend disproportionally more on public transfers and agricultural income, while middle-income families rely disproportionally more on informal employment and migrant workers' incomes

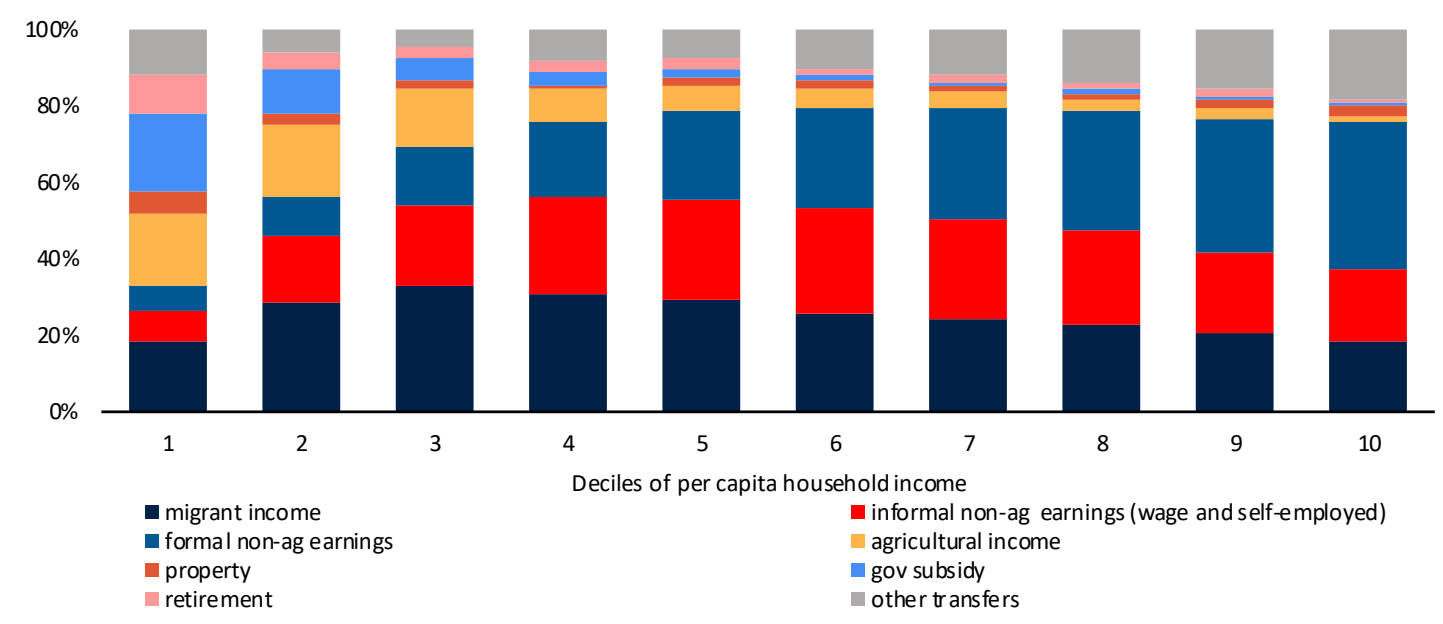

Source: China Family Panel Study 2018.

Note: Public transfers include any government subsidies, including social assistance programs (such as Dibao, Tekun), reforestation and a gricultural subsidies, work injury insura nce, and contributory and non-contributory pensions, among others.

In addition, poor families are less able to protect themselves from permanent negative shocks, as they have lower savings. Previous estimates suggest that the poorest half of households may have very little in savings or be unable to save, while the richest households save more than 50 percent of their income. ${ }^{29}$ When faced with a shock, poor and more vulnerable households will not be able to buffer themselves as well as their richer counterparts.

Differences across groups (informal vs. formal, migrants vs. urban hukou holders, women vs. men) will determine the distributional impact of the pandemic. Using macroeconomic sectoral growth projections for 2020 under no COVID-19 (benchmark-previous growth projections) and COVID-19 (crisis) scenarios, we can simulate the shock faced by households across the distribution. The model takes into account population growth and food and non-food price changes, as well as reallocation in the labor

${ }^{29}$ See (Gan, L., N. Zhao, and Y. Sun. 2018). 
market following the contraction and recovery of the different sectors. We present two crisis scenarios. The first ("Homogeneous impact" in figures below) considers that after labor reallocation, all workers within a sector see their income change at the same rate. Under the second crisis scenario ("Heterogenous impact on migrant/informal labor" in figures below), informal and migrant workers (as well as remittances from them) experience an additional loss of one and a half months of earnings.

\section{Box 9. Microsimulation model}

The estimates in this chapter use a microsimulation model to evaluate the welfare and distributional impacts of COVID-19 in 2020, following the methodology described in Habib et al. (2010) and Olivieri et al. (2014). The micro-simulation model superimposes macroeconomic sectoral growth projections on behavioral models of labor transitions and earnings determinants built on the 2018 China Family Panel Study. Specifically, the model combines sectoral growth projections in the different scenarios with employment elasticities to determine labor market adjustments in employment and earnings. We consider two aggregate employment elasticities of GDP: ILO-OECD-WBG (2015) estimate for growing sectors (benchmark and unaffected sectors under crisis scenarios) of 0.09; and J.P. Morgan (2020) elasticity of 0.01 for contracting sectors.

Labor reallocations are determined by a multinomial logit model that provides the probability of each working-age individual who is employed or not employed (either unemployed or out of the labor force) in one of the three aggregated sectors (highly affected, moderately affected, relatively unaffected). Earnings are adjusted to reflect sectoral growth under each scenario. Non-labor income is assumed to track the overall economy. Finally, the model considers population shifts between the year of the survey (2018) and the year of the projection (2020), reflecting new entrants to the labor market as well as those exiting the working age group. Population projections are from United Nations - Population Division.

Three scenarios are simulated:

- No-COVID Benchmark: This is a counterfactual scenario, business as usual, based on previous pre-COVID growth projections.

- Homogenous impact: Based on baseline macro forecast (presented in previous chapters) for the overall economy and across economic sectors. After labor reallocation, all workers within a sector see their income change at the same rate, such that the sectoral wage bill (after employment changes) grows at the same rate as the sectoral output.

- Heterogenous impact on migrant/informal labor: Also based on baseline macro forecast (presented in previous chapters) for the overall economy. But after labor reallocation, informal and migrant workers (as well as remittances from them) experience an additional loss equivalent to one and a half months of earnings. The assumption of one-and-a-half labor income loss represents the time of the lockdown and is consistent with the results by Rozelle et al. (2020) in rural villages.

The impact of the pandemic across the income distribution is assessed as the difference between the noCOVID benchmark and each of the crisis scenarios (homogenous impact and heterogenous impact).

The uncompensated impact of the COVID-19 shock on households is projected to be between -2 and -11 percent of pre-crisis incomes, depending on the scenario and location. Considering similar earnings shocks within sectors (Figure 32, red lines), households in the middle of the distribution - from the $20^{\text {th }}$ to the $80^{\text {th }}$ percentiles, or quintiles 2 to 4 - may see their income fall by around 5 percent on average in 2020, relative to the previous year. At the same time, families in the bottom and top quintiles may see a decline 
of between 3 and 4 percent. But the national average hides large discrepancies between urban and rural households. In urban areas, losses are significantly larger in the bottom half of the distribution - up to 8 percent over the year - than at the top. By contrast, the shock is smaller and more homogeneous across rural households. A differential impact for informal and migrant workers (Figure 32, blue dotted lines) will imply a much deeper contraction among the urban poor and vulnerable. Rural households are also affected, but relative losses are more concentrated in the middle of the distribution. In this second scenario, formal workers are more isolated from the shock, resulting in lower losses for the richer quintiles.

\section{Figure 32. Percentage change in per capita income in crisis scenarios relative to no-COVID benchmark}

COVID-19 will more severely impact those in the middle of the distribution, with larger losses if informal workers are disproportionally affected

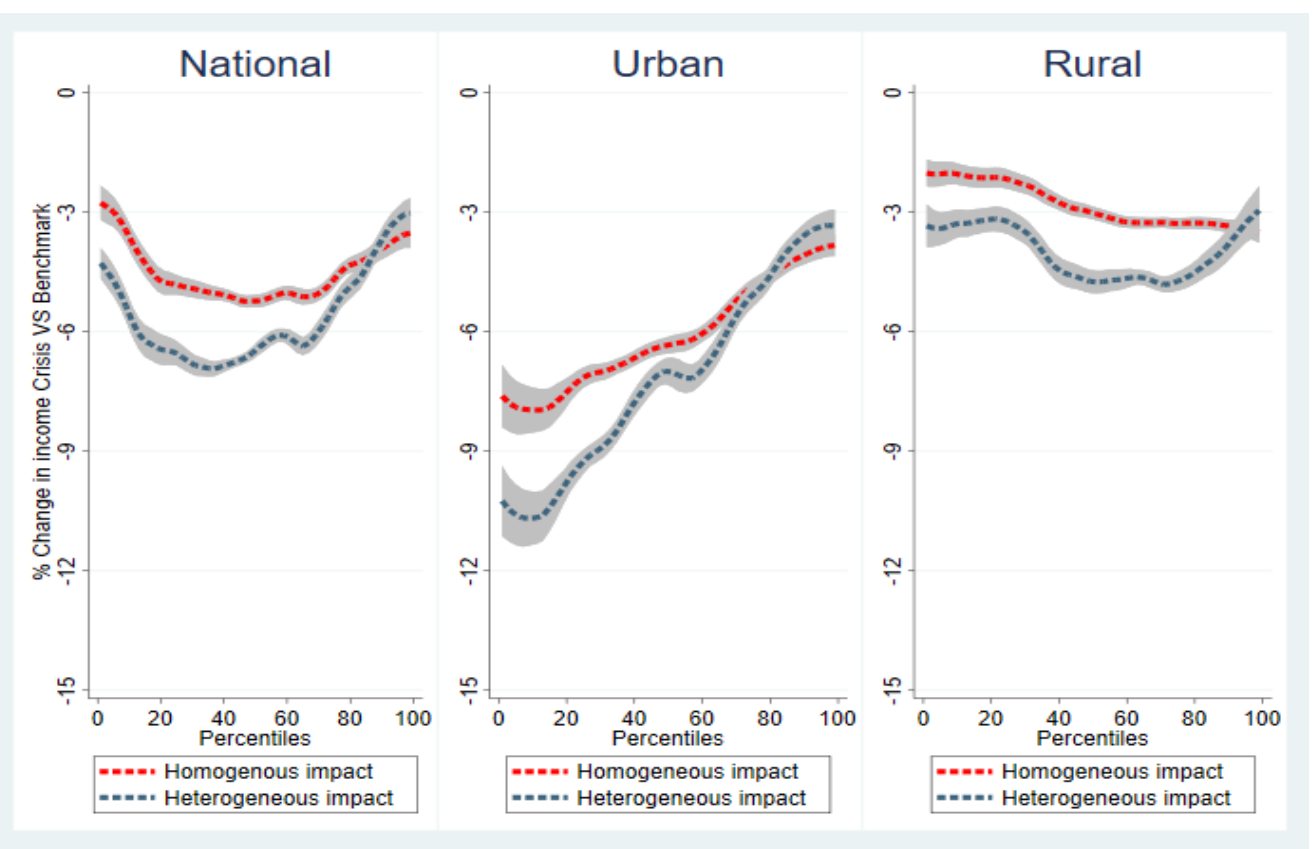

Source: Ba sed on China Fa mily Panel Study 2018.

Note: Percentiles of the national, urban, and rural distributions, respectively. Crisis scenarios refer to the 'homogeneous impact' and 'heterogeneous impact on migrant/informal labor', as defined in Box 10. 


\section{Box 10. Poverty lines used in the simulations}

Poverty is defined using the $\$ 5.50$ per person per day poverty threshold (2011 USD Purchasing Power Parity). This is the poverty line typically observed in upper-middle income countries. For 2018, the World Bank estimated that 19.5 percent of people in China fell below this threshold (World Bank 2020e). Since the present analysis uses the 2018 China Family Panel Study rather than the NBS China Integrated Household Survey, the threshold is adjusted to match the poverty rate calculated using official household expenditure data.

The present analysis is not suited to represent expected changes in official poverty rates. This is because the official poverty estimates refer only to rural areas, and less than 3 percent of rural population fall under this official threshold. The survey and methodology employed here are not able to accurately project changes for such a small proportion of the population. Furthermore, since the impact of the crisis is expected to fall more on urban areas and the middle of the income distribution, the analysis presents the expected impact across the whole country (urban and rural), with a particular focus on the lowest quintile of the income distribution to reflect the differential impact on the less well-off groups.

The income losses in 2020 translate into a slowdown in poverty reduction relative to a context without COVID-19. Despite the large expected declines in household incomes, neither crisis scenario suggests an increase in poverty rates relative to 2018 , as measured using the $\$ 5.50 /$ day per person (2011 PPP) (see Box 10 ), using either income or consumption as the welfare aggregate (Figure 33). Rather, poverty reduction continues but at a much slower rate. Similarly, reductions in poverty gaps-measured by the average shortfall to the poverty line-would slow as a result of the pandemic, due to two factors. First, 2019 was a year of growth, in which poverty reduction was expected to continue. Part of that decline would be expected to reverse in 2020, but not by enough to raise poverty above 2018 levels. Second, the largest losses are observed in the middle of the income distribution. While some households would slip back into poverty, others may see their income fall but remain above the poverty threshold. This, however, should not be regarded as evidence of a weak poverty impact. As mentioned, poorer families have a lower ability to shield themselves from shocks, even when faced with relatively small losses. Protecting their living standard is an important priority for existing social assistance programs, and the emergence of the "new poor," prompted by the crisis, represent a new challenge.

The "new poor"" are more likely to be urban, in working age, have informal work arrangements and work in affected sectors than the structural poor. Those who are poor under the crisis scenario ('homogenous impact' and 'heterogenous impact') but not poor under the no-COVID benchmark scenario are referred to as the "new poor." This group comes disproportionally from urban areas, unlike the structural poor (defined as those who are poor in all three 2020 scenarios, always poor) (Figure 34). Assuming a larger impact among informal and self-employed than formal workers ("heterogenous impact on migrants/informal') results in a significant increase in the share of informal sector workers among the new poor. As expected, it is more likely that the new poor are engaged in the more severely and moderately affected sectors. By contrast, half of the always poor are not working and a third are engaged in relatively unaffected sectors (mostly agriculture). 
Figure 33. Percentage change in the poverty rate relative to 2018 , in benchmark and crises scenarios

The shock will partly reverse the gains made in the previous year, as fewer people are expected to leave poverty than in the absence of COVID-19

A. Income-based poverty

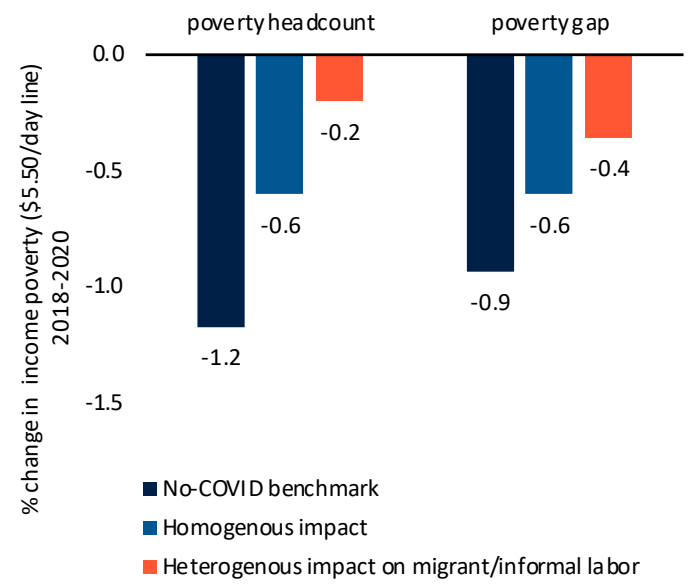

\section{B. Expenditure-based poverty}

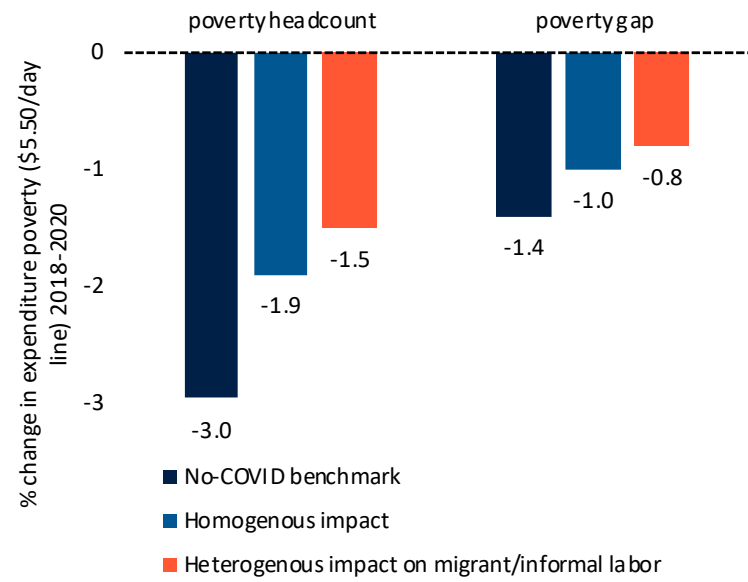

Source: China Family Panel Study 2018.

Note: Poverty is calculated using the $\$ 5.50 /$ day line (2011 PPP). See Box 10 for definition of the alternative scenarios and Box 11 for the definition of poverty.

Figure 34. Distribution of poor (aged 15-64) across scenarios

The new poor are overrepresented among urban, informal, and affected sectors compared to the always poor

A. Share of poor according to socioeconomic characteristics

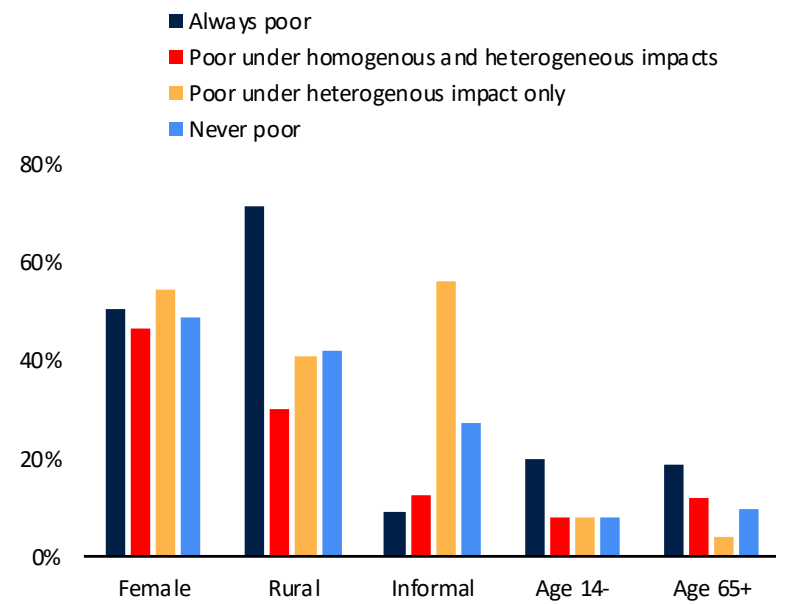

B. Distribution of poor (aged 15-64) across scenarios, depending on the economic sector of origin

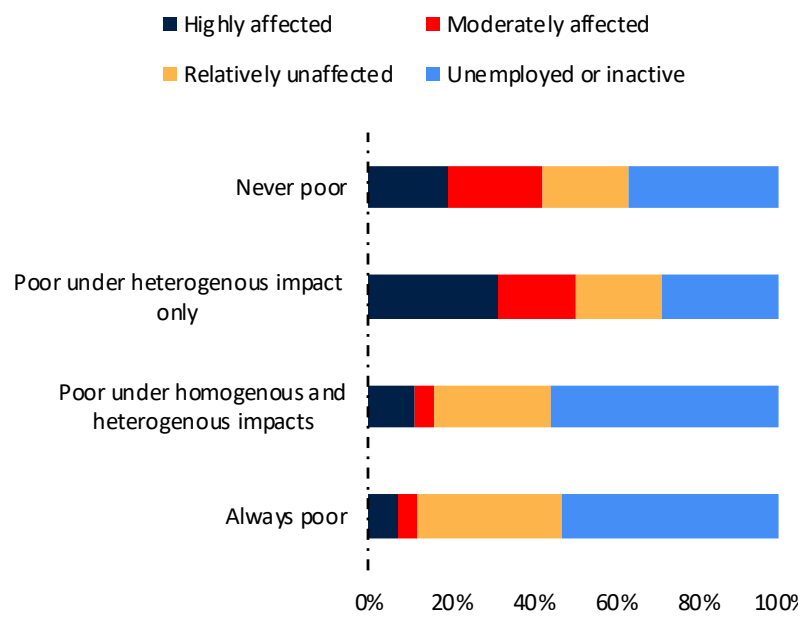

Source: Based on the China Family Panel Study 2018. "Always poor" are poor under the no-COVID benchmark and the two crisis scena rios, and "never poor" are not poor in any of the scenarios. See Box 2 for details. 
Income losses among the "new poor" could be substantial. Those who are expected to be poor in both crisis scenarios - but not under the no-COVID benchmark - would experience the largest income falls in relative and absolute term (Figure 35). On average they would lose nearly RMB 4,000 over the year per household member. In contrast, those who are expected to be poor under all scenarios would see a drop of less than 5 percent of their per capita income and around RMB 100 over the course of the year. As losses are largest among households in the second and third decile (see Figure 32), some of the new poor, in the absence of the pandemic, would have had income per capita far above the poverty threshold. This suggests that prior to the crisis, these families might not have been beneficiaries of the social protection programs targeted to the poor and vulnerable.

\section{Figure 35. Income losses among the "new poor"}

The new poor are set to experience a large loss in income, and thus some are coming from decile 3

A. Change in per capita income across poor (relative to benchmark scenario)

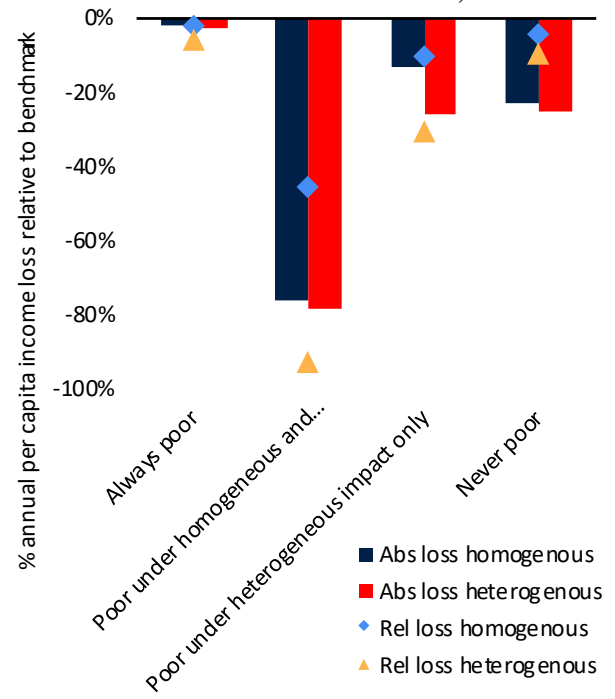

B. Distribution of the poor relative to position under benchmark scenario

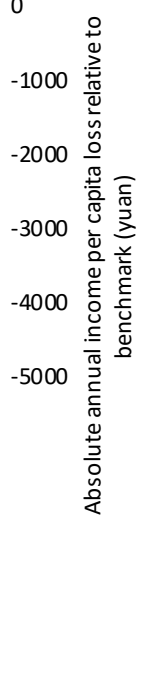

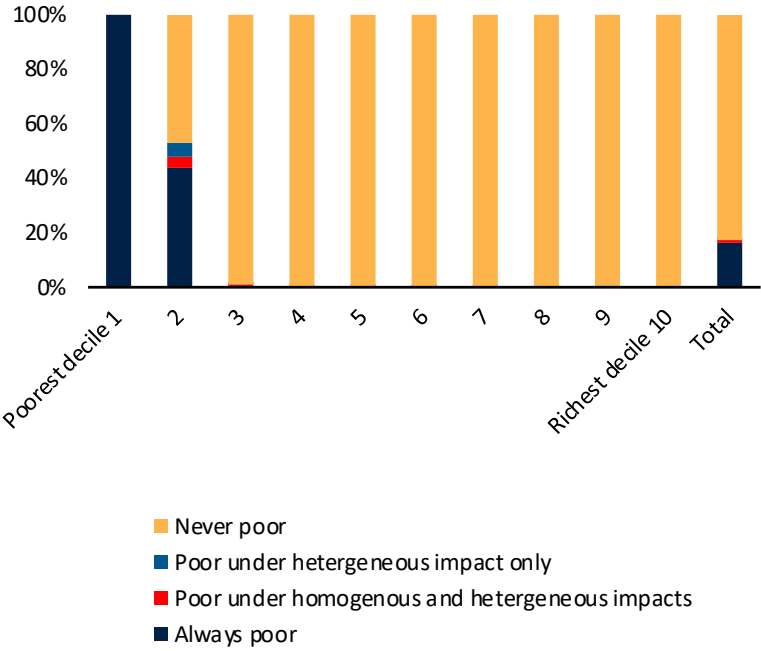

Source: Authors based on China Family Pa nel Study 2018.

Note: 'Always poor' are those that are poor under the no-COVID benchmark and the two crisis scenarios ('homogeneous impact' and 'heterogeneous impact on migrant/informal labor'), and 'never poor' are those not poor in any of the scenarios. See Box 10 for details.

\section{Government's mitigation measures}

China has a relatively comprehensive social protection system but in which the social assistance programs cover only a small share of households. In 2019, the total beneficiaries of major social assistance programs (Dibao, Tekun, and temporary assistance) amounted to 56.7 million, ${ }^{30}$ which accounted for 4.1 percent of the total population. In terms of eligibility conditions, urban and rural Dibao thresholds reached RMB 7,488 and RMB 5,335 per capita per year in 2019, respectively, well above the official rural

\footnotetext{
${ }^{30}$ Among them, 8.6 million and 34.6 million benefited from urban Dibao and rural Dibao, respectively;. Tekun beneficiaries amounted to 4.4 million and the remaining 9.2 million were beneficiaries of the temporary assistance program. Note that the statistic unit of temporary as sistance program is the frequency of as sistance units who have rec eived one-time support, which may overstate the number of beneficiaries in case the same household received it several times.
} 
poverty line of around RMB 3,000 in current prices (RMB 2,300 per capita per year in 2010 prices). The size of benefits is related to eligibility thresholds. Dibao is designed as a guaranteed minimum living standard program providing cash transfers to each household, to top up its income to the specific threshold. There are no recent estimates of how many of those potentially eligible for Dibao do not receive it, but previous data suggested 70-90 percent exclusion rates for urban and rural Dibao. ${ }^{31}$ The rapid increases of eligibility thresholds and the falling number of recipients in recent years suggests that these exclusion rates might have grown.

In response to the crisis, China has adopted sequential social protection and jobs policy measures to provide income support and facilitate the resumption of production and work. These measures largely rely on preexisting social protection programs (Table 3). They include deploying the emergency assistance program to provide income and social support for stranded people during the lockdown, topping up Dibao benefits for existing beneficiaries, temporarily providing unemployment insurance benefits to workers not covered by formal labor contracts, and extending social protection programs to migrant workers. The latter change is an important feature of China's social protection policy response. A public works program was also introduced in the rural areas to increase the labor income of poor workers. In the meantime, China has also taken proactive labor market policy measures to help firms retain jobs and facilitate labor mobility, such as the "point-to-point" charted transportation to assist stranded migrants returning to work and reskill workers to meet the demand of new employment opportunities. In parallel, fiscal and monetary macroeconomic policies have been introduced as part of the package to promote economic recovery in China.

Public spending for China's social protection and jobs policy response is estimated to be $\mathbf{1 . 6 5}$ percent of the 2019 GDP. The Chinese government has announced the expansion and temporary extension of existing social protection and jobs policies for the remainder of 2020. Table 3 shows the fiscal costs of these measures from official data. An extrapolation for an estimate of public spending was made for social insurance contribution exemptions, unemployment insurance refunds, and Dibao top-ups over 2020. China's social protection and jobs programs are financed by national and local governments, but due to the unavailability of local-level data, the cost estimates fail to capture local public spending. For that reason, the estimate presented should be interpreted as a lower-bound. Compared to the average of 0.51 percent of GDP in upper middle-income countries ${ }^{32}$ China's social policy response to COVID-19 is substantially higher. In per capita terms, social spending is estimated to reach $\$ 165$ per person, which is lower than the average for North America (\$295) but much higher than the averages in the East Asia and Pacific region. ${ }^{33}$ It is noteworthy that the major component of public spending for China's social protection and jobs policy response comes from social insurance, which aims to maintain employment stability.

Table 3. Key social protection and labor policies in response to COVID-19

\begin{tabular}{|l|l|l|}
\hline \multicolumn{1}{|c|}{ Policies } & \multicolumn{1}{|c|}{ Spending } & \multicolumn{1}{c|}{ Beneficiaries } \\
\hline Social Assistance $(\mathbf{S A})$ & Emergency a ssistance: & - Emergency a ssistance: 15,000 \\
- Provide emergency income and social support & RMB 37.6 million $(\$ 5.3$ & $\begin{array}{l}\text { received ca sh transfers and 6,000 } \\
\text { received temporary resettlement }\end{array}$ \\
to the stra nded population & million) by March 2020; & by March 2020 \\
- Top up Dibao benefits for ex isting & Dibao top-up: RMB 156 & by - SA top-up: 62 million by March \\
beneficiaries and expand coverage to the new & billion (\$22 billion) by & 2020 \\
poor & June 2020 & \\
\hline
\end{tabular}

\footnotetext{
${ }^{31}$ Ravallion and Chen (2015), Yang (2013), and Golan et al. (2017).

32 According to the World Bank estimates reported in Gentilini et al. 2020 (version: June 12, 2020).

${ }^{33}$ Ibid.
} 


\begin{tabular}{|c|c|c|}
\hline $\begin{array}{l}\text { Social Insurance (SI) } \\
\text { Provide unemployment in surance (UI) ben efits } \\
\text { for unemployed workers and migrant workers } \\
\text { Exempt and defer SI contributions of } \\
\text { employers } \\
\text { Refund UI contributions to firms }\end{array}$ & $\begin{array}{l}\text { SI exemption: RMB } 600 \\
\text { billion ( } \$ 84.6 \text { billion) by } \\
\text { June } 2020 \text {; } \\
\text { - UI refund: RMB } 38.8 \\
\text { billion }(\$ 5.5 \text { billion }) \text { by } \\
\text { April } 19,2020\end{array}$ & $\begin{array}{l}- \text { UI benefits: } 2.38 \text { million workers } \\
\text { by March } 2020 \\
\text { - SI exemption: primarily SMEs } \\
\text { - UI refund: } 3.02 \text { million } \\
\text { enterprises, covering } 80.8 \text { million } \\
\text { workers, by April } 192020\end{array}$ \\
\hline $\begin{array}{l}\text { Labor Market } \\
\text { Facilitate mobility and create more job } \\
\text { opportunities for migrant workers } \\
\text { Offer Active La bor Market Policies for the } \\
\text { unemployed and migrant workers }\end{array}$ & $\begin{array}{l}\text { Public work: RMB 5.6 } \\
\text { billion (\$790 million) by } \\
\text { May } 2020\end{array}$ & $\begin{array}{l}- \text { Mobility support: } 5.9 \text { million } \\
\text { migrant workers by March } 2020 \\
\text { - Public works: } 300,000 \text { poor rural } \\
\text { and migrant workers by May, } \\
2020\end{array}$ \\
\hline
\end{tabular}

Source: Compiled by World Bank staff based on available official data.

Due to limited coverage provided by existing social assistance programs, members of the middle class who were hard hit by the crisis are likely to be excluded and may not be able to receive timely support. For the "new poor," the average loss of incomes due to COVI-19 is about RMB 3,000 over the course of 2020 , but the estimate is much lower for the other groups. The average value of top-ups is RMB 2,500 per beneficiary for the duration of benefit. Assuming that social assistance coverage increased by 10 percent (based on the reported total number of recipients), new beneficiaries are now 4.4 percent of the population, up from 4.1 percent prior to the crisis. This means that the RMB 2,500 on average as the top-up would cover five-sixths of the income loss for the "new poor" and will probably be sufficient to keep them out of poverty. However, the expansion of coverage is not sufficient to cover all the "new poor," who will remain outside the public safety net. Moreover, to the extent that some of those who were poor before the crisis continue to be excluded from social welfare programs, their welfare losses, however small, will also remain uncompensated and may lead to long-term damage to human capital, as discussed in the next subsection.

\section{Non-monetary impacts of COVID-19}

Beyond monetary impacts, the social consequences of the pandemic seem to have a pronounced gender differentiated pattern. In China, men have higher COVID-related mortality rates compared to women, ${ }^{34}$ but the burden of socio-economic cost fell disproportionately on women. First, due to occupational segregation, women were more likely to serve as nurses on the front lines, with higher odds of contacting the virus (as many as 90 percent of nurses in Hubei were women). Second, gender roles meant women took on a larger share of the additional burden of domestic chores. Women in China spend 2.5 more time on unpaid care work than men, averaging almost four hours a day. ${ }^{35}$ With school and business closures, as well as the breakdown of childcare and elderly care services, women's domestic duties increased further, and multiplied if a family member became sick. Third, recent data suggest a possible rise in domestic violence during the pandemic, particularly against women. ${ }^{36}$ All of these factors may dramatically affect women's labor force participation, and could reverse years of social progress, as suggested by the international evidence. ${ }^{37}$

\footnotetext{
34 See (The Novel Coronavirus Pneumonia Emergency Response Epidemiology Team. 2020).

${ }^{35}$ See (ILO. 2018).

${ }^{36}$ UN Women 2020. The survey for China shows an increase in 50 percent of reports and calls to the police. (Zhang Wanqing, 2020)

37 Global evidence is summarized in the World Bank (2020f). A more detailed region-specific analysis is given for Latin America by Bartels-Bland, E. (2020). Alon, T. et al (2020) estimate that for the US, that unlike in a typical recession, women are poised to suffer larger losses from COVID-19.
} 
COVID-19 may also lead to lasting damage to human capital accumulation. Disruptions in the provision of health services and fears of getting infected while obtaining routine health care may be particularly harmful for those with existing or undiagnosed chronic conditions and the elderly, as well as young children who need vaccinations and regular check-ups. In addition, school disruptions, absent a robust policy response, may lead to learning losses with potentially long-term consequences for children's educational attainment, employability, productivity, and welfare. ${ }^{38}$

China has proactively deployed policies to minimize learning losses, but inequities in learning have likely grown. The Ministry of Education promoted the "Suspending Classes Without Stopping Learning" initiative to continue teaching while schools were closed. But differences in guidance and the uneven availability of digital resources and stable connection across the country could have important implications for educational equity across locations. ${ }^{39}$

The health system was largely able to maintain the delivery of services, but with differences across regions. A number of measures were taken to protect frontline health workers and to ensure surge capacity where it was needed most. The government also waived out-of-pocket payment for COVID-19 diagnosis and treatment. Online consultations (telemedicine) were promoted by both the government and industry during the outbreak, which enabled patients who were not suffering from COVID-19 to continue to receive care. This was particularly important for elderly people, who are at the greatest risk during the pandemic. However, the capacity to deliver both online and community-based solutions differed across regions and population groups. For many patients around the country, including those with chronic conditions, COVID19 has led to a disruption in access to services. In January and February of 2020, the use of outpatient and inpatient services decreased (by 21.3 and 17.2 percent, respectively for these two months), compared to 2019, for all provinces except Hubei. While the outbreak impacted hospitals more severely for the provision of outpatient services, it impacted primary care providers for inpatient service provision. ${ }^{40}$

Inequalities in access to quality public services reflect differences in economic endowments across regions and the design of inter-governmental fiscal relations, but also restrictions to labor mobility. The hukou household registration system reduces migrant workers' access to quality social services in more developed urban areas, including public health services. Local governments are responsible for most expenditures for health, education, and social protection, but often lack sufficient revenue bases to fund these obligations, which points to the presence of vulnerabilities that exacerbated the impact of income losses for certain groups.

\section{Forward looking agenda}

The COVID-19 crisis has demonstrated the gaps in China's current social protection system, despite of the substantial support provided and the temporary increase in coverage. The size and potential persistence of income shocks raises the question of how long temporary top-ups to benefits should be maintained. Moreover, disruptions in access to education and health services may also require longer-term support to ensure they do not translate into permanent inequalities in human capital endowments. Beyond these crisis-related policy responses, however, the simulations presented above raise the question whether China's poverty reduction efforts are too narrowly targeted. The emergence of a potential cohort of "new poor" among self-employed and migrant workers in urban areas points to emerging social policy challenges beyond the eradication of absolute poverty, a key policy goal for 2020. In this regard, the following areas merit additional consideration by policy makers:

\footnotetext{
${ }^{38}$ World Bank. 2020b.

39 Wunonget al. 2020.

40 ibidem.
} 
- Expand the social assistance programs vertically and horizontally. This means expanding coverage to new beneficiaries and increasing the value of transfers. Both goals can be achieved by increasing Dibao eligibility thresholds. The current coverage of Dibao is low, and the thresholds are not high for an upper-middle income country. In addition, the program does not fully cover all those who are potentially eligible based on their incomes and assets conditions. Expanding social assistance programs to migrant workers and vulnerable groups could help mitigate their income loss and boost domestic consumption. In the longer term, such reform may also be helpful to achieve an inclusive urbanization. For this, the central government can play a leading role in policy design and financing as it did in response to the pandemic, leading to a greater consistency in coverage and benefit adequacy across the country.

- Strengthen the role of unemployment insurance. The unemployment insurance scheme is vital for mitigating labor market risks and helping protect and reemploy the unemployed. Before the crisis, unemployment insurance was tied to labor contracts and covered less than 50 percent of the urban labor force. Most migrant workers were not covered. In response to the crisis, the conditions for claiming unemployment insurance benefits were relaxed and an unemployment insurance allowance or temporary living allowance were introduced to cover migrant workers. Upgrading and expanding unemployment insurance functions will require improved monitoring of the labor market, as well as reforming the eligibility conditions to also cover workers without local hukou.

- Customize labor market policies for specific groups severely affected by the crisis. Various active labor market policies, such as vocational training, online job fairs, mobility support, and public works, have been carried out to support the unemployed, migrant workers, and college graduates. These policies will help people avoid the scarring effects of unemployment and maintain their employability. Further demand-driven training needs assessments could equip them with adequate skills through customized training programs and help bridge the gaps between labor market demand and supply. An important prerequisite to facilitating stronger active labor market programs will be an enhanced labor market information system that is fully inclusive of migrant workers, as well as being more inter-operable across jurisdictions.

- Increase public spending to invest in people. The government's stimulus package continues to be focused on investment in infrastructure, particularly "new" infrastructure, such as in 5G, Artificial Intelligence, Internet of Things, and the industrial internet. Investing in the next new generation infrastructure is important but investing in people will be crucial to increasing human capital and creating the conditions for innovative and high-quality growth. These investments will require increased public spending in social sectors, including health, education, and social protection and active labor market programs. Expanding social protection coverage to migrant workers and to a wider spectrum of vulnerable population groups is eminently affordable. Similarly, reductions in the burden of social contributions could be sustained into the postpandemic era, thereby encouraging formal job creation, whilst adjusting social insurance to the reality of demographic change. Gaps in revenues could be covered by general government resources up to a basic level of provision.

- Deepen structural reforms for a stronger, job-intensive recovery and to facilitate adjustment of the labor market to the post-pandemic economy. Some of the current interim measures such as exempting employers' social security contributions are important for securing employment stability in the short run but could burden the long-term financial sustainability of China's social security system. Ultimately, a strong and sustained recovery will be essential for easing pressures on the labor market. In this regard, fiscal and monetary policy setting s should remain appropriately 
accommodative to bolster the recovery of domestic demand, as discussed in part 1 of this report. Accommodative macroeconomic policies to support the recovery of aggregate demand could be accompanied by structural reforms to stimulate a stronger supply response. Further market reforms in areas such as land, capital and labor markets as well as steps to improve the business environment would facilitate entrepreneurship and help create conditions for job creation. Reforms to address barriers to labor mobility, including further liberalization of the Hukou system and enhanced access to and portability of social services together with job search and upskilling support to the unemployed would facilitate movement of labor from firms and sectors suffering more persistent damage to expanding sectors, firms, and locations. 


\section{References}

Alon, T., M. Doepke, J. Olmstead-Rumsey, and M. Tertilt. 2020. "The Impact of COVID-19 on Gender Equality," NBER Working Paper No. 26947, National Bureau of Economic Research, Cambridge, MA.

Ball, L. 2014. "Long-Term Damage from the Great Recession in OECD Countries," European Journal of Economics and Economic Policies: Intervention 11 (2): 149-160.

Bartels-Bland, E. 2020. "COVID-19 Could Worsen Gender Inequality in Latin America and the Caribbean." World Bank, Washington, DC, feature story.

Botha, B., Ruch, F., and Steinbach, R. 2018. "Short-Lived Supply Shocks to Potential Growth." South African Reserve Bank Working Paper WP/18/02. South African Reserve Bank, Pretoria, ZA.

Constantinescu, C., A. Mattoo, and M. Ruta. (forthcoming). "Policy Uncertainty, Trade and Global Value Chains: Some Facts, Many Questions." Review of Industrial Organization

DRC and World Bank. 2019. Innovative China: New Drivers of Growth. Washington, DC: World Bank. Freund, C., A. Mattoo, A. Mulabdic, M. Ruta. 2020. "The Supply Chain Shock from COVID-19: Risks and Opportunities." World Bank, Washington, DC, mimeo.

Gan, L. 2020. "How the 600 million fare during/after the pandemic?" Conference on relative poverty measurement with application to China, Beijing, June.

Gan, L., N. Zhao, and Y. Sun. 2018. "Income Inequality, Liquidity Constraints, and China's Household Saving Rate.” Economic Research Journal (in Chinese 经济研究) 53 (12): 34-50.

Gentilini, U., M. Almenfi, P. Dale, A.V. Lopez, I.V. Mujica, R. Quintana, and U. Zafar. 2020. "Social Protection and Jobs Responses to COVID-19: A Real-Time Review of Country Measures." World Bank, Washington, DC. (Version 11, June 12, 2020)

Golan, J., T. Sicular, and N. Umapathi. 2017. "Unconditional Cash Transfers in China: Who Benefits from the Rural Minimum Living Standard Guarantee (Dibao) Program?” World Development 93 (5): 316-336.

Habib, B., A. Narayan, S. Olivieri, and C. Sanchez-Paramo. 2010. "Assessing Ex Ante the Poverty and Distributional Impact of the Global Crisis in a Developing Country: A Micro-simulation Approach with Application to Bangladesh.” Policy Research Working Paper 5238, World Bank, Washington, DC.

Huang C., Wang Y., Li X., Ren L., Zhao J., Hu Y., Zhang L., et al. 2020. "Clinical Features of Patients Infected with 2019 Novel Coronavirus in Wuhan, China.” The Lancet 395 (10223): 497-506.

ILO-OECD-WBG. 2015. “G20 Labour Markets in 2015: Strengthening the Link Between Growth and Employment.” Report prepared for the G20 Labour and Employment Ministers Meeting and Joint Meeting with G20 Finance Ministers, Ankara, Turkey, September 3-4.

ILO. 2018. Care Work and Care Jobs for the Future of Decent Work. Geneva, Switzerland: ILO.

Johns Hopkins University Coronavirus Resource Center. 2020. “COVID-19 Dashboard.” Accessed July 6. https://coronavirus.jhu.edu/map.html

J.P. Morgan, Global Research Reports. 2020. Assessing China's Labor Market Conditions. Economic Research Note.

Keogh-Brown, M.R., Smith, R.D., Edmunds, J.W., and Beutels, P. 2010. “The Macroeconomic Impact of Pandemic Influenza: Estimates from Models of the United Kingdom, France, Belgium and The Netherlands." European Journal of Health Economics 11 (6): 543-554. 
Kilbourne, E. D. 2004. "Influenza Pandemics: Can We Prepare for the Unpredictable?" Viral Immunology 17 (3): 350-357.

Kose, M.A., P. Nagle, F. Ohnsorge, and N. Sugawara, eds. 2019. Global Waves of Debt: Causes and Consequences." Washington, DC: World Bank Group.

Li Q., Guan X., Wu P., Wang X., Zhou L., Tong Y., Ren R., et al. 2020. “Early Transmission Dynamics in Wuhan, China, of Novel Coronavirus-Infected Pneumonia." New England Journal of Medicine 382 (13): 1199-1207.

McKibbin, W. and R. Fernando. 2020. "The Global Macroeconomic Impacts of COVID-19: Seven Scenarios.” Brookings Working Paper. https://www.brookings.edu/wpcontent/uploads/2020/03/20200302_COVID19.pdf

McKinsey. 2020. "How Chinese Consumers Are Changing Shopping Habits in Response to COVID-19." https://www.mckinsey.com/featured-insights/asia-pacific/how-chinese-consumers-are-changingshopping-habits-in-response-to-covid-19

Moody's. 2020. "Regional banks are most vulnerable to the coronavirus outbreak." Sector In-depth, Moody's Investors Service, April 29, 2020

National Health Commission of the People's Republic of China. 2020. "COVID-19 Case Report." Accessed July 6. http://www.nhc.gov.cn/xcs/yqtb/202001/c5da49c4c5bf4bcfb320ec2036480627.shtml

NBS (National Bureau of Statistics, China). 2020. "Views on the First Quarter Indicator Changes." http://www.stats.gov.cn/tjsj/sjjd/202004/t20200420_1739722.html

Olivieri, S., S. Kolenikov, S. Radyakin, M. Lokshin, A. Narayan, and C. Sanchez-Paramo. 2014. "Simulating Distributional Impacts of Macro-Dynamics: Theory and Applications." World Bank, Washington, DC.

Ravallion, M. and S. Chen. 2015. "Benefit Incidence with Incentive Effects, Measurement Errors and Latent Heterogeneity: A Case Study for China." Journal of Public Economics 128 (2015): 124-132.

Rozelle, S., H. Rahimi, H. Wang, and E. Dill. 2020. “Lockdowns Are Protecting China's Rural Families from COVID-19, But the Economic Burden Is Heavy" International Food Policy Research Institute (blog), March 30. https://www.ifpri.org/blog/lockdowns-are-protecting-chinas-rural-families-covid-19economic-burden-heavy

The Novel Coronavirus Pneumonia Emergency Response Epidemiology Team. 2020. "The Epidemiological Characteristics of an Outbreak of 2019 Novel Coronavirus Diseases (COVID-19)China." China CDC Weekly, 2 (8): 113-122.

UN Women. 2020. "Impact of COVID-19 on Violence Against Women and Girls and Service Provision: UN Women Rapid Assessment and Findings." https://www.unwomen.org/en/digitallibrary/publications/2020/05/impact-of-covid-19-on-violence-against-women-and-girls-and-serviceprovision

Wanqing, Z. 2020. “Domestic Violence Cases Surge During COVID-19 Epidemic.” Sixth Tone, March 2, 2020.

World Bank. 2012. People, Pathogens and Our Planet: The Economics of One Health. June. Washington, DC: World Bank.

World Bank. 2016a. Global Economic Prospects: Spillovers amid Weak Growth. June. Washington, DC: World Bank.

World Bank. 2018. Global Economic Prospects: Broad-Based Upturn, But for How Long? January. Washington, DC: World Bank. 
World Bank. 2019. China Economic Update, December 2019: Cyclical Risks and Structural Imperatives December. Washington, DC: World Bank.

World Bank. 2020a. Global Economic Prospects: Slow Growth, Policy Challenges. January. Washington, DC: World Bank.

World Bank. 2020b. “The COVID-19 Pandemic: Shocks to Education and Policy Responses.” Policy Note, World Bank, Washington, DC.

World Bank, 2020c. "Projected Poverty Impacts of COVID-19 (Coronavirus)." June. https://www.worldbank.org/en/topic/poverty/brief/projected-poverty-impacts-of-COVID-19.

World Bank. 2020d. Global Economic Prospects: Pandemic, Recession: The Global Economy in Crisis. June. Washington DC: World Bank.

World Bank. 2020e. "Macro Poverty Outlook for East Asia and the Pacific." Washington DC: World Bank.

World Bank. 2020f. Gender Dimensions of the COVID-19 Pandemic. Washington, D.C: World Bank.

World Bank. 2020g. Global Investment Competitiveness Report 2019/2020: Rebuilding Investor Confidence in Times of Uncertainty. Washington, DC: World Bank.

World Bank. 2020h. World Development Report 2020: Trading for Development in the Age of Global Value Chains. Washington, DC: World Bank.

World Bank-International Monetary Fund. 2020. “COVID-19: The Regulatory and Supervisory Implications for the Banking Sector," Joint WB-IMF Staff Position Note. May. International Monetary Fund, Washington, DC.

Xinhuanet. 2020. "China's Daily Nucleic Acid Testing Capacity Tops 3 Mln: Official." http://www.xinhuanet.com/english/2020-06/24/c_139163797.htm, June 24.

Yang, L. 2013. "The Urban Dibao Programme in China: Targeting and Its Effect." Indian Journal of Labour Economics 56 (4): 597-615.

Zhang, W., Y. Wang, L. Yang, and C. Wang. 2020. "Suspending Classes Without Stopping Learning: China's Education Emergency Management Policy in the COVID-19 Outbreak." Journal of Risk and Financial Management 13 (3): 1-6. 
